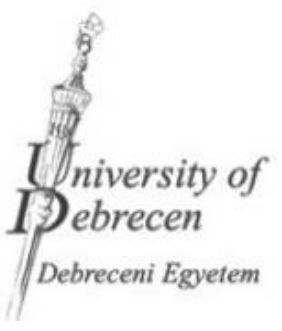

\title{
KÜLÖNLEGES BÁNÁSMÓD
}

INTERDISZCIPPLINÁRIS

(OPEN ACCES - NYÍLT HOZZÁFÉRÉSÜ)

SZAKMAI LAP

ISSN 2498-5368

Web:

http://old.gyfk.unideb.hu/kulonlegesbanasmod/

III. évf., 2017/4. szám

DOI 10.18458/KB.2017.4.1 


\title{
IMPRESSZUM
}

\section{KÜLÖNLEGES BÁNÁSMÓD - INTERDISZCIPLINÁRIS SZAKMAI LAP}

\begin{abstract}
Alapítva: 2014-ben.
A Nemzeti Média- és Hírközlési Hatóság Hivatala a médiaszolgáltatásokról és a tömegkommunikációról szóló 2010. évi CLXXXV. törvény 46.§ (4) bekezdése alapján nyilvántartásba vett sajtótermék (határozatról szóló értesítés iktatószáma: CE/32515-4/2014).
\end{abstract}

Kiadó: Debreceni Egyetem

A kiadó székhelye:

Debreceni Egyetem

4032 Debrecen, Egyetem tér 1.

Kiadásért felelős személy:

Szilvássy Zoltán József, rector (Debreceni Egyetem)

\author{
A szerkesztőség levelezési címe: \\ Debreceni Egyetem \\ Gyermeknevelési és Felnőttképzési Kar \\ Különleges Bánásmód folyóirat szerkesztősége \\ 4220 Hajdúböszörmény, Désány István u. 1-9. \\ Tel/fax: 06-52/229-559 \\ E-mail: titkarsag@ped.unideb.hu \\ Web: www.degyfk.hu \\ Szerkesztésért felelős személy: \\ Mező Ferenc (Eszterházy Károly Egyetem) \\ Tördelőszerkesztő: Mező Ferenc, Mező Katalin
}

\section{Alapító főszerkesztő: Mező Ferenc}

Tanácsadó testület ( $\mathrm{ABC}$ rendben):

Balogh László (Magyar Tehetséggondozó Társaság, Magyarország)

Gerevich József (Eötvös Lóránd Tudományegyetem, Magyarország)

Hatos Gyula ( Magyarország)

Koncz István (Professzorok az Európai Magyarországért Egyesület, Magyarország)

Mesterházy Zsuzsanna (Eötvös Lóránd Tudományegyetem, Magyarország)

Nagy Dénes (Melbourne University, Ausztrália)

Varga Imre (Szegedi Tudományegyetem, Magyarország)

\section{Szerkesztőség (ABC rendben):}

Bernáth Krisztina (Partiumi Keresztény Egyetem, Románia)

Dávid Mária (Eszterházy Károly Főiskola,

Magyarország)

Egri Tímea (Eötvös Lóránd Tudományegyetem, Magyarország)

Fónai Mihály (Debreceni Egyetem, Magyarország)

Horváth László (Debreceni Egyetem, Magyarország)

H. Tóth István (Károly Egyetem, Csehország)

János Réka (Babes-Bolyai Tudományegyetem, Románia)

Lepeš, Josip (University of Novi Sad, Szerbia)

Kelemen Lajos (Poliforma Kft., Magyarország)

Kiss Szidónia (Babes-Bolyai Tudományegyetem,

Románia)

Kondé Zoltánné Dr. Inántsy-Pap Judit (Debreceni

Egyetem, Magyarország)

Kormos Dénes (Miskolci Egyetem, Magyarország)

Láda Tünde (Debreceni Egyetem, Magyarország)
Márton Sándor (Debreceni Egyetem, Magyarország) Mező Katalin (Debreceni Egyetem, Magyarország) Molnár Balázs (Debreceni Egyetem, Magyarország) Nagy Lehocky Zsuzsa (Konstantin Filozófus Egyetem Nyitra, Szlovákia)

Nemes Magdolna (Debreceni Egyetem, Magyarország)

Roskó Tibor (Debreceni Egyetem, Magyarország)

Sarka Ferenc (Miskolci Egyetem, Magyarország)

Schéder Veronika (Debreceni Egyetem, Magyarország)

Szabó Edina (Debreceni Egyetem, Magyarország)

Szilágyi Barnabás (Debreceni Egyetem, Magyarország)

Vargáné Nagy Anikó (Debreceni Egyetem,

Magyarország)

Vass Vilmos (Budapesti Metropolitan Egyetem,

Magyarország)

Váradi Natália (II. Rákóczi Ferenc Kárpátaljai magyar

Főiskola, Ukrajna)

Note: The title of the journal comes from a Hungarian Act CXC of 2011. on National Public Education in which they use the term 'Különleges Bánásmód', and this translates as Special Treatment, but this encompasses the areas of Special Educational Needs, Talented Children and Children with Behaviour and Learning Difficulties. The adoption of Special Treatment is therefore in accordance with Hungarian law, but it is recognised that the translation may not be perfect in expressing the full meaning of what is encapsulated in this term. 


\section{TARTALOM}

EMPIRIKUS ÉS ÉRTEKEZŐ TANULMÁNYOK 5

R. Fedor Anita és Fónai Mihály

A magasan kvalifikált fiatal munkavállalói csoportok elemzésének új megközelítési lehetősége: a prekaritátus .. 7

Bocsi Veronika, Csercsa Zsuzsanna, Csobay Vanessza, Karmacsi Kitti, Kreidl Edina, Kőszegi Ildikó, Pálfi Regina

Az egyetem peremén. A DE GYFK hallgatói bázisának szociokulturális háttere

Meiszerné Kuklek Noémi, Pusztafalvi Henriette

A munkaerő-piaci integráció hatásai, különös tekintettel a magatartás és életminőség változásaira

Pálosi Rita és R. Fedor Anita

A tanulási motivációk és a munkaerö-piaci elvárások összefüggései .....

MÓDSZERTANI TANULMÁNYOK

Mályusz Enikő és Mező Katalin

Diszlexiával németül

Lázár Tímea és Bene Ágnes

(Pro)aktivitás egy nemzetközi nagyvállalt magyar leányvállalatának társadalmi felelősségvállalásában 77 


\section{EMPIRIKUS ÉS ÉRTEKEZŐ}

TANULMÁNYOK 


\title{
A MAGASAN KVALIFIKÁLT FIATAL MUNKAVÁLLALÓI CSOPORTOK ELEMZÉSÉNEK ÚJ MEGKÖZELÍTÉSI LEHETŐSÉGE: A PREKARIÁTUS
}

\author{
Szerzők: \\ R. Fedor Anita \\ Debreceni Egyetem \\ Egészségügyi Kar \\ Fónai Mihály \\ Debreceni Egyetem \\ Állam- és Jogtudományi Kar \\ Első szerző e-mail címe: \\ fedor.anita@foh.unideb.hu
}

\author{
Lektorok: \\ Bódi Ferenc \\ MTA Társadalomtudományi Kutatóközpont \\ Fábián Gergely \\ Debreceni Egyetem \\ Egészségügyi Kar \\ Bocsi Veronika \\ Debreceni Egyetem \\ Mező Katalin \\ Debreceni Egyetem
}

R. Fedor, Anita \& Fónai, Mihály (2017): A magasan kvalifikált fiatal munkavállalói csoportok elemzésének új megközelítési lehetősége: a prekariátus. Különleges Bánásmód, III. évf. 2017/4. szám, 7-17. DOI 10.18458/KB.2017.4.7

\begin{abstract}
Absztrakt
Írásunkban a friss-diplomások munkaerő-piaci jellemzőit mutatjuk be, egy új, eddig még kevesek által használt elméleti megközelítés, a prekariátus szemüvegén keresztül. Célunk annak feltérképezése, hogy az általunk vizsgált általában kedvezőbb munkaerő-piaci helyzetben lévő társadalmi csoportban mennyire jellemzőek a prekariátus jelenség egyes ismérvei. Tanulmányunkban a prekariátus fogalmát, mint egyfajta munkaerő-piaci bizonytalanságot definiáljuk, melyben olyan kedvezőtlen munkafeltételek koncentrálódnak, mint bizonytalan, rövid távú munkák, határozott idejü munkaszerződés, alacsony bér stb. Ezen jellemzők az anyagi biztonság hiányán túl egy általános létbizonytalansághoz, esetlegesen munkaerő-piaci és társadalmi kirekesztődéshez vezethetnek (LaVaque-Manty 2012, Standing 2012).

Elemző munkánkban arra keressük a választ, hogy a diplomás fiatalok körében mennyire érhető tetten a prekariátus, mint bizonytalan munkaerő-piaci helyzet, s hogy e jelenség mely fó magyarázó változók mentén értelmezhető a leginkább. Kérdésként vetődik fel, a szociodemográfiai, a szociokulturális jellemzők, ezen belül a nem, a családi állapot a megszerzett iskolai végzettség szintje (alap- vagy mesterdiploma, Phd. fokozat), a szakképzettség jellege, a település típusa határozza-e meg leginkább a munkaerö-piaci érvényesülés mikéntjét?

Előzetes eredményeink a nők már korábban is tapasztalt munkaerő-piaci hátrányát erősítik meg. Körükben - a férfiakhoz viszonyítva - például magasabb a határozott munkaszerződéssel foglalkoztatottak aránya, s a munkaerőpiaci-karrier megszakítása is inkább a nőkre jellemző. A "Most nem dolgozom, de már volt munkahelyem" kérdésre igennel válaszolók magasabb
\end{abstract}


arányban kerültek ki a nők köréből. Mindez azt jelzi előre, hogy a kevésbé stabil, kevésbé biztonságos munkaerő-piaci jellemzők inkább a nőket érintik.

Kulcsszavak: fiatalok, kirekesztődés, munkaerőpiac, prekariátus

Diszciplina: szociológia

\begin{abstract}
The study focuses on the labour-market situation of young graduates utilizing the database of the Hungarian Graduate Tracking System. The purpose of the research is to map certain characteristics of the precarious situation posed by the labor market on this group which is in a rather favorable labor market position in comparison to other groups. The concept of precariate is defined as a type of labor-market uncertainty, in which unfavorable working conditions, like insecure short-term jobs, fixed-term employment contracts, low wages, etc.are concentrated.

In addition to the lack of financial security, these characteristics may lead to general insecurity and in some cases to labor market and social exclusion (LaVaque-Manty 2012, Standing 2012). This analysis focuses on the presence of a precarious condition which creates an insecure labour-market situation among young graduates and it attempts to find the main explanatory variables in the interpretation of this phenomenon.

In addition it investigates whether socio-demographic, socio-cultural characteristics, like gender, marital status, type of qualification (BSc, MSc or Ph.D degree), and the type of settlement (village, town, city etc.) affect success in the labour-market. Preliminary results support previous studies that found women in the labor market were disadvantaged. For example, the proportion of women with a fixed employment contract is higher than men, and the interruption of a labor market career is more characteristic of women. More women gave a positive answer to "I am not working at the moment although I have previously had a work place". This suggests that women are more affected by a less stable and less secure labor market than men.
\end{abstract}

Keywords: young people, exclusion, labour-market, precariate

Disciplines: sociology

\title{
Bevezetés
}

A munkaerö-piaci érvényesülést - valamint annak hiányát - számos tényező befolyásolja. Ilyen lehet például a megszerzett iskolai végzettség, a szak vagy szakma típusa, annak szektorális jellege, a munkaerö-piacon megszerzett tapasztalat. Emellett számos egyéni jellemző is alakítja a munka világában való helytállás sikerességét. Ilyen például az alkalmazkodó képesség, tanulékonyság, a szervezeti hierarchia elfogadása. Mindemellett azt is meg kell említeni, hogy bizonyos családi életciklusokban jellemzőbb az instabil munkaerőpiaci helyzet. Ilyen például a gyermekvállalásból adódó lazább munkaerő-piaci kötődés. Ebben az értelemben a hátrányos munkaerő-piaci státuszú csoportokhoz soroljuk a gyermekeket nevelő nőket, a pályakezdőket, az alacsony iskolai végzettségüeket, a községi lakóhellyel rendelkezőket. Ezen csoportok munkavállalási mintázatát számos hazai és külföldi kutatás vizsgálta. Azonban kérdésként vetődik fel, hogy az alapvetően kedvező munkaerőpiaci kondícióval rendelkező frissdiplomások csoportjában fellelhetőek-e karakteres 
munkaerő-piaci hátrányok, $\mathrm{s}$ amennyiben igen milyen föbb dimenziók mentén értelmezhetők a különbségek. Korábbi vizsgálataink elméleti hátterét az inklúzióhoz, integrációszegregációhoz kapcsolódó elméleti keretek adták. Jelenlegi vizsgálatunkban azonban egy új elméleti megközelítéshez nyúlunk, a prekariátus jelenségéhez.

Tanulmányunkban elsőként bemutatjuk a prekariátus definiálásának, és operacionalizálásának lehetőségeit, majd a magyarországi Diplomás Pályakövető Rendszer adatbázisára (2015) támaszkodva bemutatjuk a fiatal diplomások munkaerő-piaci helyzet, úgy hogy kiemelve kezeljük az ún. prekár jellemzőket.

\section{A vizsgálat elméleti hátterét adó új megközelités: a prekariátus}

A prekariátus, mint fogalom a '70-es évek végén jelent meg - elsősorban - a francia szakirodalomban. A fogalmat sokáig a kirekesztés definíciójához hasonlóan az új szegénységhez kapcsolódó talajvesztés jelenségével jellemezték, majd a meghatározás keretei szépen lassan szúkültek, s ma már leginkább a munka világához kapcsolódik, egyfajta bizonytalan munkaerő-piaci helyzetet demonstrálva. A prekariátus a 2000-es évek elején került az akadémiai érdeklődés fókuszába, majd rövid átmeneti csendet követően 2012-ben Gay Standing írása hatására erősödött fel az érdeklődés a jelenség tudományos igényü megközelítése iránt. A prekariátusnak vagy prekaritásnak legjobb tudomásunk szerint jelenleg két megközelítési formája van: a politikai és a gazdasági (Ferge 2012).

\section{A prekariátus, mint politikai és gazdasági jelenség}

Nelsion és Rossiter az úgynevezett prekár munkavállalókról (alkalmi munkavállalók vagy rugalmas dolgozók) a következőt írták: „a politika olyan új alanyaiként próbáljuk meghatározni vagy elképzelni, amelyek bövelkednek a kollektív szervezödés és önkifejezés rájuk jellemzö, sajátos formáiban” (Lazzarato 2004 idézi Nelsion és Rossiter 2009:102) Lazzarato megfogalmazásában nem válik élesen ketté e két társadalmi (al)rendszer szerinti meghatározás. Véleménye szerint a prekaritás sokkal szélesebb és összetettebb kategória. Nem csupán a prekár munkavállalók helyzetét magába foglaló fogalom, hanem egy jóval általánosabb egzisztenciális állapotot tárgyal, amely egyszerre tekinthető úgy, mint ,a politikai elnyomás, a gazdasági kizsákmányolás és a megragadandó lehetőségek forrása" (Lazzarato 2004 idézi Nelsion és Rossiter 2009:102). Mindezek értelmében a bizonytalan munkahelyek mellett a prekaritás aspektusaiként rajzolódtak ki az életminőséget meghatározó különböző tényezők (szerzők), mint például a lakáshelyzet, a jövedelmi bizonytalanságból adódó eladósodás, a jóléti ellátások köre és igénybevételének lehetősége, a személyes emberi kapcsolatok építésére és fenntartására rendelkezésre álló idő stb.

\section{A prekariátus, mint munkaerö-piaci csoport}

Standing (2012) szerint a prekariátus elsősorban bérmunkásokból álló csoport, akik általában a bizonytalannak tekintett határozott munkaidejü szerződéssel, alacsony munkabérért dolgoznak. Tovább részletezve a jellemzőket Kelemen és Rakovics (2013) a prekariátust, mint állandósult bizonytalanságérzet mutatják be, mely a munka világában való folyamatos jelenlét hiányából adódik. Az állandó munkahely hiányának következménye pedig a munkahelyi társas kapcsolatak (melyek elsősorban formális kapcsolatok, de idővel ezek informálissá is válhatnak, ami egy erősebb kötődést és ezzel együtt erősebb védőhálót is jelenthet az érintettek számára) és a tervezhető jövőkép hiánya. A prekaritás tehát munkaeröpiaci jelenségként a biztonságtól való megfosztottságot kiszolgáltatottságot jelenti (Tordai (é. n). Szépe (2012) szerint a prekariátus, mint munkaerő-piaci csoport olyan emberi tőke tekintetében heterogén csoport, akinek munkaerő-piaci helyzete instabil (idézi Sik és Szeitl 2016). 
Azonban azt sem szabad elfelejteni, ezek a bizonyos prekár jellemzők, mint például részmunkaidő, határozott munkaidejü szerződés bizonyos társadalmi csoportok esetében inkább lehetőséget jelentenek és nem hátrányt. Gondoljunk mondjuk a diákokra, akik nyári szünetben dolgoznak, vagy azokra az egyetemi hallgatókra, akik hallgató jogviszonyuk mellett alkalmi, vagy részmunkát vállalnak azért, hogy ki tudják fizetni a tandíjukat, vagy az albérletük díját. Bár az is igaz, hogy ők munkaerő-piaci szempontból a gazdaságilag inaktívak kategóriájába tartoznak.

\section{Női prekarizmus - Férfi prekariazmus}

A munkaerő-piaci helyzet általános jellemzője, hogy a nők foglalkoztatása általában elmarad a férfiakétól. Mindemellett, az is tapasztalható, hogy a nök körében általában erösebb a prekariátus jelensége, mivel körükben magasabb a rövid távú, határozott idejü munkaszerződéssel dolgozók aránya, valamint jellemzőbb rájuk a munkaerő-piaci jelenlét folytonosságának megszakítása, például gyermekvállalás alkalmával. Ez Európában, ÉszakAmerikában és Japánban is jellemező trend (Standing 2012). A nők munkaerő-piaci jelenléte viszont elengedhetetlen a család megélhetése szempontjából. Azonban az is egyre inkább nyilvánvalóvá válik, hogy a korábban „kettős teherként” említett családanyai és foglalkoztatotti szerep egyfajta „, hármas teherré” duzzadt az elmúlt két évtizedben (Standing 2012), mikor is a gyermeknevelés és a munka világában való jelenlét kettős teherviselése mellett megjelenik egy későbbi életciklusban az idős szülőkről, családtagokról való gondoskodás is. Mindez tovább rontva ennek a csoportnak az egyébként is bizonytalan munkaerö-piaci helyzetét. Megoldást jelentene az, ha az otthoni gondozó feladatokhoz piaci bér társulna (mely hazai viszonylatban a gyermekgondozáshoz kapcsolódóan a munkaerőpiaci tapasztalattal rendelkező nők esetében meg is valósul). Addig azonban a nők az idős hozzátartozók ápolását, gondozását szabadidejükben, vagyis a „harmadik müszakban” végzik. Még aggasztóbb a helyzet annak tudatában, hogy ma már egyre általánosabbá válik a nők körében a korábban elsősorban férfiakra jellemző kenyérkereső szerep. Ennek oka nem csak abban keresendő, hogy nő az egyszülős családok száma, hanem abban is, hogy átalakultak a társadalmi szerepek.

Bár írásunk fö irányvonalát nem a női preakariátus adja, mégis érdemesnek ítéljük az iménti kitekintést, ugyanis a nők, ezen belül is a gyermeket nevelő nők munkaerő-piaci hátránya vitathatatlan. Éppen ezért a munkaerö-piaci jellemzők nemek szerinti mintázatának feltárása meghatározó momentuma lesz a lentebb olvasható elemző munkánknak. Még mielött azonban erre rátérnénk, ejtsünk néhány szót a férfiak hátrányáról. Ezt azért tartjuk fontosnak, mert a társadalomtudományi diskurzusok mintha megfelejtkeznének a férfiakról. A fentiek alapján kérdésként vetődik fel, hogy a férfiakat érinti-e és ha igen milyen módon a prekariátus jelensége. A válasz egyértelmüen igen. A megváltozott társadalmi szerepek hatására a nők munkaerő-piaci megjelenésével és foglalkoztatotti karrierjük építésének lehetőségével csökkent a házastársuk munkaerö-piaci karrierjéért önmaguk karrierjét feláldozó nők aránya. Mindezt azt jelenti, hogy egyre inkább megfigyelhetők a kettős karrierü családok, vagyis az, hogy mind a férfiak, mind a nők lehetőségeik szerint arra törekszenek, hogy szorosan kötődjenek a munkaerőpiachoz.

Visszatérve az eredeti kérdésünkhöz - igen, a férfiaknak is van veszíteni valójuk a munka világában. Gondoljuk a 2008-as pénzügyi válságra, melynek munkaerö-piaci negatív hatása számokban mérhető, s mely számos tanulmány alapját képezte. A válsággal párhuzamosan kialakuló munkaerő-piaci nehézség világszerte a férfiakat és ezen belül is a szakképzett férfiakat érintette. Nem volt ez másképpen hazai viszonylatban sem, ráadásul a korábbiakkal ellentétben nem a legalacsonyabb foglalkoztatási színvonallal rendelkező megyék, régiók férfi 
munkavállalói váltak a válság áldozatává, hanem a legkedvezőbb munkaerő-piaci lehetőségekkel rendelkező megyékben, régiókban élök.

\section{Empirikus elemzésünk jellemzői}

\section{Módszer}

Elemzésünkben arra keressük a választ, hogy a magasan kvalifikált fiatal munkavállalókra mennyire jellemző a prekariátus, mint bizonytalan munkaerő-piaci helyzet. Érintik vajon őket munkaerö-piaci nehézségek, és ha igen milyen fö meghatározó jellemzők mentén írhatók le tipikus vagy tipikusnak nem mondható mintázatok. Részben a diplomás fiatalok helyzetét vizsgálta egy, a prekariátust a centrum - periféria egyenlőtlenségi rendszerébe illesztő kutatás, melynek több eredményét figyelembe vettük saját elemzésünk tervezésekor (Szabó, 2017).

A prekariátushoz kapcsolódó első hazai empirikus vizsgálat Sik Endre és Szeitl Blanka (2016) nevéhez füződik, akik az „Integráció és dezintegráció” kutatás és az ISSP 2015. évi adatfelvétel adatbázisát használták fel munkájukhoz. Vizsgálatukban öt, illetve két változó mentén értelmezték a prekariátust.

\section{1. táblázat A prekariátus jellemzői/ismérvei. (Forrás: Sik és Szeitl 2016.)}

\begin{tabular}{|l|c|}
\hline $\begin{array}{c}\text { International Social Survey Program } \\
\text { alapján }\end{array}$ & $\begin{array}{c}\text { „Integráció és dezintegráció” kutatás } \\
\text { alapján }\end{array}$ \\
\hline - Munkaerő-piaci helyzet & $\bullet \begin{array}{l}\text { A munkaerőpiacon belüli mozgás (pl. } \\
\text { az elmúlt } 5 \text { évben) ennek megfelelően } \\
\text { megkülönböztettek stabil és instabil } \\
\text { munkaerö-piaci pozíciót, }\end{array}$ \\
- Szubjektív anyagi helyzet & $\begin{array}{l}\text { Az emberi tőke mértékével } \\
\text { - Társadalmi osztály }\end{array}$ \\
- Emberi töke & összefüggő beosztás \\
\hline
\end{tabular}

Mindezeket figyelembe véve saját kutatómunkánkban a Sik és Szeitl (2016) által meghatározott változókat, illetve attól eltérőeket határoztunk meg prekár mutatókként: gazdasági aktivitás, munkaszerződés, munkaidő jellege, családi állapot, nem, van-e gyerek a csalágban. Az iskolai végzettség azért nem került a vizsgálatunk kiemelt magyarázó változói közé, mert elemzésünk alapját eleve a diplomával rendelkező fiatalok adták.

\section{Minta és eszközök}

Kutatásunkhoz a Diplomás Pályakövető Rendszer adatbázisát használtuk fel (az adatgazda engedélyével). A DPR keretein belül 2015 tavaszán 34 felsőoktatási intézmény hallgatói fejezhették ki véleményüket különböző témacsoportok kérdéseire válaszolva. Az adatgyüjtés online kérdőívek segítségével történt, melyet több mint húszezren töltöttek ki. A lekérdezés teljes körü volt a 2010-ben, 2012-ben és 2014-ben abszolutóriumot szerzettek körében. Az általunk elemzett 2015-ös felmérés az alábbi témákat tartalmazta:

- tanulmányi életút (felsőfokú tanulmányok időszaka, felsőfokú továbbtanulás),

- külföldi tapasztalatok (nyelvismeret, külföldi tanulmányok, külföldi munkavállalás),

- átmenet a felsőoktatás és a munkaeröpiac között (a diplomaszerzés kitolódása, munkatapasztalat diplomázás előtt, első munkahely), 
- a frissdiplomás munka és munkahely, jövedelem

E témakörök közül az utolsó kettőre fókuszáltunk.

\section{Eljárás}

Elemző munkánkhoz az SPSS 22. statisztikai programcsomagot használtuk. Elemzésünkben egyváltozós és többváltozós elemzési technikákat alkalmaztunk. Előbbi segítségével átfogó képet kaptunk az adatbázisról, utóbbiak alkalmazása lehetővé tette két vagy több változó közötti összefüggések feltárását. Az elemzés során a leggyakrabban használt többváltozós elemzési formák közé tartozott a kereszttábla-elemzés valamint a $\chi^{2}$ statisztika.

\section{Eredmények}

Mielőtt bemutatjuk elemzésünk főbb eredményeit, elötte röviden szólunk a vizsgált minta néhány általános jellemzőjéről. Elsősorban azokra a paraméterekre koncentrálunk, melyeket később a prekár mutatókkal összefüggésben vizsgálni fogunk.

A megkérdezett fiatalok 61\%-a nő, 39\%-a pedig férfi. Családi állapot szerint a következő jellemzőkkel bírnak: 41\% egyedülálló, 26,7 \%-uk házas, 29,4\% élettársi kapcsolatban él, $2,6 \%$ elvált és $0,4 \%$ válaszolta azt, hogy özvegy. A nök körében magasabb a házasok, az elváltak és a tartós kapcsolatban élők aránya a férfiakhoz viszonyítva, míg az egyedül állók létszáma a férfiaknál magasabb.

Egyötödük nevel 18 év alatti gyermeket. Ezen belül a többség egy gyermekröl $(58,2 \%)$ gondoskodik. 32,4\%-uk két, 8,3\%-uk három, háromnál több gyermeke pedig 1\%-uknak van.

A megkérdezettek 36\%-a az abszolutórium megszerzését követően egy hónapon belül talált munkát, $10,5 \%$ pedig arról számolt be, hogy a megkérdezés időpontjában is munkát keres.

A válaszadók 6,3 \%-a dogozott már külföldön és közel ennyien válaszolták azt, hogy jelenleg is külföldi munkahelyük van. Többségük (70\%) külföldi munkája részben vagy egészben kapcsolódott a megszerzett diplomához. 28\%-uk tervezi, hogy elkövetkezendő 5 éven belül külföldön fog majd dolgozni.

A mintába került fiatalok munkaerő-piaci státusz szerinti mintázatáról a következő kép rajzolódott ki: többségük, 85\%-uk a gazdaságilag aktívak csoportjába sorolta magát, ezen belül is négyötödük alkalmazottként dolgozik. Jelenleg is nappali tagozatos hallgató $6,2 \%$, míg 3,7\% munka nélkül van. Gyermekgondozási szabadság miatt 3,7\%-uk van távol a munka világától, a háztartásbeli, valamint az egyéb inaktív eltartott státuszban lévők aránya egy százalék alatti. Közel egyharmaduk megtapasztalta már a munkanélküliséget a végzést követően.

A frissdiplomások munkaerő-piaci részvételi kedvező képet fest, 88\%-uk dolgozott a megkérdezés időpontjában. 8,4\% válaszolta azt, hogy bár most nem dolgozik, de volt már munkahelye, s 3,4\% pedig még sohasem dolgozott. Azok, akik a megkérdezési időpontjában dolgoztak többségében $(82,7 \%)$ állandó, határozatlan időtartamra szóló szerződésser rendelkeztek. 14,7 \%-uk határozott munkaszerződéssel lett foglalkoztatva, míg 2,7\% alkalmi jellegü, megbízási szerződéssel dolgozott.

A gazdasági aktivitást a képzési szinttel összefüggésben vizsgálva szignifikáns eredményeket kaptunk $(p=0,000)$. A 2. számú táblázat eredményei azt mutatják, hogy minden képzési típusban az alkalmazottak vannak a legtöbben. Ehhez képest alacsony és közel azonos az önfoglalkoztatók és vállalkozók aránya. Ami szembetűnő, hogy az alapszakkal (Ba/BSc) rendelkezők körében a legmagasabb a munkanélküliek aránya. A második legmagasabb adat a mesterszakot végzettekhez kötődik. A legjobb helyzetben az egységes és osztatlan képzésbe valamint a hagyományos egyetemi, föiskolai képzésben végzettek vannak. A végzettek egy része nappalis hallgatóként jelenik meg újra a felsőoktatás rendszerében. Kiemelten igaz ez az 
alapszakon diplomát szerzettek esetében, akik részéről ez agy logikus döntésként értelmezhetö, a fentebb leírtak ismeretében (2. táblázat).

2. táblázat. Mi az Ön jelenlegi fö munkaerö-piaci státusza? (\%) N=19645. (Forrás: R. Fedor és Fónai)

\begin{tabular}{|c|c|c|c|c|c|c|c|c|}
\hline 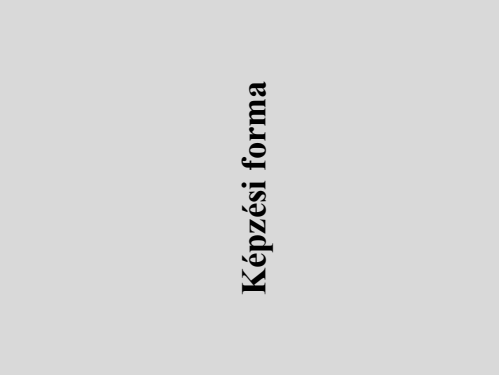 & 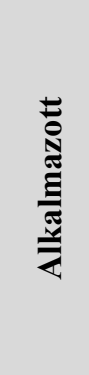 & 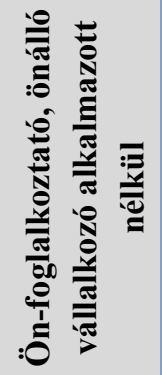 & 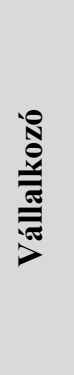 & 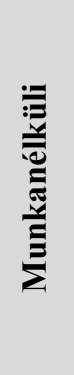 & 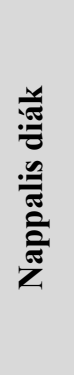 & 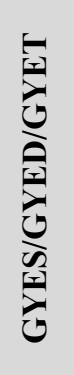 & 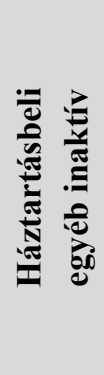 & : \\
\hline $\mathbf{B a} / \mathbf{B S c}$ & 78,0 & 2,4 & 2,2 & 4,4 & 8,8 & 3,2 & 1,1 & 100,0 \\
\hline Ma/MSc & 84,6 & 2,4 & 2,4 & 3,6 & 3,9 & 2,7 & 0,4 & 100,0 \\
\hline $\begin{array}{l}\text { Egységes és osztatlan képzés (pl. } \\
\text { jogász, orvosképzés) }\end{array}$ & 85,5 & 2,3 & 1,6 & 1,7 & 3,1 & 5,1 & 0,8 & 100,0 \\
\hline Egyetemi - hagyományos képzés & 81,6 & 4,0 & 2,8 & 2,0 & 2,8 & 6,1 & 0,7 & 100,0 \\
\hline Főiskolai - hagyományos képzés & 84,4 & 2,2 & 2,1 & 2,9 & 1,6 & 5,7 & 1,2 & 100,0 \\
\hline
\end{tabular}

$\left(\chi^{2} \mathrm{p}=0,000\right)$

Arra is kíváncsiak voltunk, hogy a munkaerö-piaci részvétel hogyan alakul, külön vizsgálva a férfiakat és nőket. Alapvető különbséget találtunk a levelezőn és nappalin végzett hallgatók válaszaiban. Nem meglepő, hogy a levelezősök között vannak a legtöbben azok, akik úgy nyilatkoztak, hogy jelenleg is dolgoznak, hiszen ök általában éppen azért választják a levelező tagozatot, hogy a tanulmányikat össze tudják egyeztetni a munkahelyi feladataikkal. Ami viszont figyelemre méltó, az az, hogy mind a nappalin, mind a levelezőn végzettek csoportján belül a nők a férfiakhoz képest nagyobb arányban számoltak be megszakított munkaerö-piaci jelenlétről, vagyis arról, hogy ,,most nem dolgozik, de volt már munkahelye”. Bár a válaszokból az nem derül ki, hogy a megszakított munkaerő-piaci karriernek mi az oka, mégis kijelenthetjük, hogy a folytonos munkaerö-piaci jelenlét hiánya - amely egyértelmúen egyfajta bizonytalanságként értelmezhető - inkább jellemző a nőkre, mint a férfiakra. (3. táblázat)

3. táblázat. Munkaerő-piaci részvétel szerinti megoszlás (\%) $N=20$ 996. (Forrás: R. Fedor és Fónai)

\begin{tabular}{|c|r|r|r|r|}
\hline & Nő (nappali) & Férfi (nappali) & Nö (levelező) & Férfi (levelező) \\
\hline Jelenleg (is) dolgozik & 76,8 & 82,1 & 88,8 & 95,5 \\
\hline Sosem dolgozott & 9,3 & 8,4 & 0,6 & 0,7 \\
\hline $\begin{array}{c}\text { Most nem dolgozik, de már } \\
\text { volt munkahelye }\end{array}$ & 13,9 & 9,5 & 10,6 & 3,8 \\
\hline Összesen & 100,0 & 100,0 & 100,0 & 100,0 \\
\hline
\end{tabular}

$\left(\chi^{2} \mathrm{p}=0,000\right)$ 
Ugyanez mondható el egy következő prekár mutatóról, az alkalmi, megbízási vagy határozott idejü munkaszerződésröl. A nappalis férfiak 19,9\%, míg a nappalis nők 28,2\%-a rendelkezik e csekélyebb munkabiztonságot jelentő szerződéstípussal. (lásd. 4. táblázat)

4. táblázat A munkaszerzödés jellege és a képzési forma (\%) N=17 056. (Forrás: R. Fedor és Fónai)

\begin{tabular}{|c|r|r|r|r|}
\hline & Nő (nappali & Férfi (nappali) & Nő (levelezö) & Férfi (levelezö) \\
\hline Határozatlan, állandó & 71,8 & 80,1 & 88,5 & 91,0 \\
\hline Határozott & 24,0 & 16,2 & 10,1 & 7,7 \\
\hline $\begin{array}{c}\text { Alkalmi vagy megbízási } \\
\text { jellegü }\end{array}$ & 4,2 & 3,7 & 1,4 & 1,3 \\
\hline Összesen & & & & 100,0 \\
\hline
\end{tabular}

$\left(\chi^{2} \mathrm{p}=0,000\right)$

A gyermek/gyermekek jelenléte várakozásainkkal ellentétes összefüggést mutat a munkaszerződések jellegével. Azt feltételeztük, hogy a gyerekesek körében magasabb lesz az alkalmi, megbízási vagy határozott idejü munkaszerződéssel bírok aránya, mint a gyermekteleneknél. Ennél a feltevésünknél abból indultunk ki, hogy a gyermek jelenlétéből adódó nagyobb felelösség, anyagi teher afelé irányítja a munkavállalókat, hogy akár kedvezőtlenebb munkafeltételek mellett is elvállaljanak egy adandó munkalehetőséget. Eredményeink azonban azt mutatják, hogy a gyermekesek 10,6\%-a, míg a gyermektelenek 21,4\%-ra jellemzőek az ilyen típusú szerződések. Ez két tényező „számlájára írható”.

Az egyik az életkori hatás, a másik pedig a gyermek jelenlétével összefüggő kockázatmentes munkavállalási attitüd. Az életkori hatásról a következőket gondoljuk: a gyermektelenek vélhetően a fiatalabbak, akik munkaerő-piaci pályafutásuk elején pályakezdőként többször találkoznak és fogadnak el az alkalmi, megbízási vagy határozott idejü lehetőségeket. A gyermekkel összefüggő biztonsági attitüd pedig azt jelentheti, hogy a gyermekesek nem mennek bele instabil helyzetekbe. Inkább választják a hosszabb időre szóló $\mathrm{s}$ talán kevesebb kreativitást, nagy kiugrást jelentő, de ugyanakkor kockázatmentes lehetőséget, mint a gyermektelenek. (5. táblázat)

5. táblázat Munkaszerzödés jellege és gyermek (\%) N=16 866. (Forrás: R. Fedor és Fónai)

\begin{tabular}{|c|r|r|}
\hline & Van gyermeke & Nincs gyermeke \\
\hline Határozatlan, állandó & 89,4 & 78,6 \\
\hline Határozott & 8,8 & 18,0 \\
\hline $\begin{array}{c}\text { Alkalmi vagy megbízási } \\
\text { jellegü }\end{array}$ & 1,8 & 3,4 \\
\hline Összesen & 100,0 & 100,0 \\
\hline
\end{tabular}

$\left(\chi^{2} \mathrm{p}=0,000\right)$

A munka világában való folyamatos jelenlét a gyermektelenek előnyét mutatja $(9,2 \%)$. A gyermeket nevelök körében közel kétszer ennyien válaszolták azt, hogy volt már munkahelyük, de jelenleg nem dolgoznak (6. táblázat). 
6. táblázat Munkaerö-piaci részvétel és gyermek (\%) N=19 316. (Forrás: R. Fedor és Fónai)

\begin{tabular}{|c|r|r|}
\hline & Van gyermeke & Nincs gyermeke \\
\hline Jelenleg (is) dolgozik & 82,1 & 83,5 \\
\hline Sosem dolgozott & 1,1 & 7,3 \\
\hline $\begin{array}{c}\text { Most nem dolgozik, de már } \\
\text { volt munkahelye }\end{array}$ & 16,8 & 9,2 \\
\hline Összesen & 100,0 & 100,0 \\
\hline$\left(\chi^{2} \mathrm{p}=0,000\right)$ & &
\end{tabular}

A munkaerő-piaci hierarchiában elfoglalt kedvező helynek sokféle elönye van. Magasabb jövedelmet, több szabadidőt, saját időbeosztást kínálhat az érintettek számára. Mindemellett az is fontos, hogy az emberi tőkéjébe beruházó egyén befektetései megtérülnek-e a munkaerőpiacon? Ebben az értelemben azt vizsgáltuk, hogy a frissdiplomások végzettségüknek megfelelöen diplomás munkakörben dolgoznak-e vagy sem? Az alábbi táblázatok (7. és 8.) egyértelmü női hátrányról árulkodnak. Mind a felsö-, közép- és alsó vezetők körében alulreprezentáltak a nők.

Összesítve a három vezetői szinten arányukat, azt tapasztaljuk, hogy 17\%-uk tölt be valamilyen vezetői pozíciót, míg a férfiaknál ugyan ez az arány $26,7 \%$. Még kedvezötlenebb kép tárul elénk a gyermeket nevelő nőket és férfiakat összehasonlítva. A férfiak dominanciája 43,3\%-ban mérhetö a nök 23,4\%-kához képes. A $20 \%$-os különbség jelentős, melyet megerősít korábbi megyei vizsgálatunk eredménye, mely szerint az esetek 95\%-ban a nők maradnak otthon a gyermekükkel gyermekgondozási szabadságon (R. Fedor, 2105). A megszakított munkaerő-piaci karrier jellemzője pedig, hogy az otthon töltött időszakban a nők munkaerö-piaci karrierje nem csak stagnál, de akár egy lefelé történő mobilitás is megfigyelhető (Róbert és Bukodi, 2002). Az is figyelemre méltó, hogy a „beosztott nem diplomás" státuszra vonatkozó adatok szintén a nők hátrányát erősíti.

7. táblázat Vezetö pozícióban dolgozók aránya nemek és gyermek szerint (\%) $N=14858$. (Forrás: R. Fedor és Fónai)

\begin{tabular}{|c|r|r|r|r|}
\hline Beosztás & \multicolumn{1}{|c|}{ Nő } & \multicolumn{1}{c|}{ Férfi } & Nő gyermekkel & \multicolumn{1}{c|}{ Férfi gyermekkel } \\
\hline Felsővezető & 2,2 & 3,2 & 4,0 & 6,7 \\
\hline Középvezető & 8,6 & 13,1 & 13,9 & 23,6 \\
\hline Alsó vezető & 6,2 & 10,4 & 5,5 & 13,0 \\
\hline Beosztott diplomás foglalkozás & 67,8 & 62,7 & 61,8 & 46,5 \\
\hline Beosztott nem diplomás foglalkozás & 15,2 & 10,6 & 14,7 & 10,2 \\
\hline Összesen & 100,0 & 100,0 & 100,0 & 100,0 \\
\hline
\end{tabular}

$\left(\chi^{2} \mathrm{p}=0,000\right)$

A gyerekkel rendelkező felsővezetők és középvezetők 60\%-a férfi, a középvezetőknél ez az arány még magasabb, 66\%. A nagyságrendbeli különbségek a beosztás további szintjein megfordulnak, a beosztott diplomás és nem diplomás foglalkozást betöltők a nők ,javára” fordul át. Ezekben a kategóriákban a nők arány a meghatározó (61 és 63\%) (8. táblázat). 
8. táblázat. Vezetö pozícióban dolgozók aránya nemek és gyermek szerint (\%) $N=14548$ (Forrás: R. Fedor és Fónai)

\begin{tabular}{|c|c|c|c|c|c|}
\hline & $\begin{array}{c}\text { Felsö } \\
\text { vezető }\end{array}$ & $\begin{array}{c}\text { Közép- } \\
\text { vezető }\end{array}$ & $\begin{array}{c}\text { Alsó } \\
\text { vezető }\end{array}$ & $\begin{array}{c}\text { Beosztott diplomás } \\
\text { foglalkozás }\end{array}$ & $\begin{array}{c}\text { Beosztott nem } \\
\text { diplomás foglalkozás }\end{array}$ \\
\hline Nő gyermekkel & 41,7 & 41,2 & 33,6 & 61,2 & 63,1 \\
\hline Férfi gyermekkel & 58,3 & 58,8 & 66,4 & 38,8 & 36,9 \\
\hline Összesen & 100,0 & 100,0 & 100,0 & 100,0 & 100,0 \\
\hline
\end{tabular}

$\left(\chi^{2} \mathrm{p}=0,000\right)$

Végezetül arra is kíváncsiak voltuk, hogy mennyire elégedettek a frissdiplomások a munkájuk bizonyos paramétereivel. Ezen túl az is felmerült kérdésként, hogy van-e különbség a férfiak és nők véleményében.

Megállapíthatjuk, hogy a munka összességével, tartalmi részével, tárgyi és személyi körülményeivel nagyjából hasonló mértékü elégedettségüket fejezték ki a válaszadók. Ettől valamivel alacsonyabb elégedettség jellemzi a szakmai előmenetel lehetőségét, a presztízst és a jövedelmet. Utóbbi került a rangsor végére. A férfiak és nők munkával kapcsolatos elégedettsége között meghatározó különbséget nem tapasztaltunk (9.ábra).

9. ábra. Mennyire elégedett a munka....(Forrás: R. Fedor és Fónai)

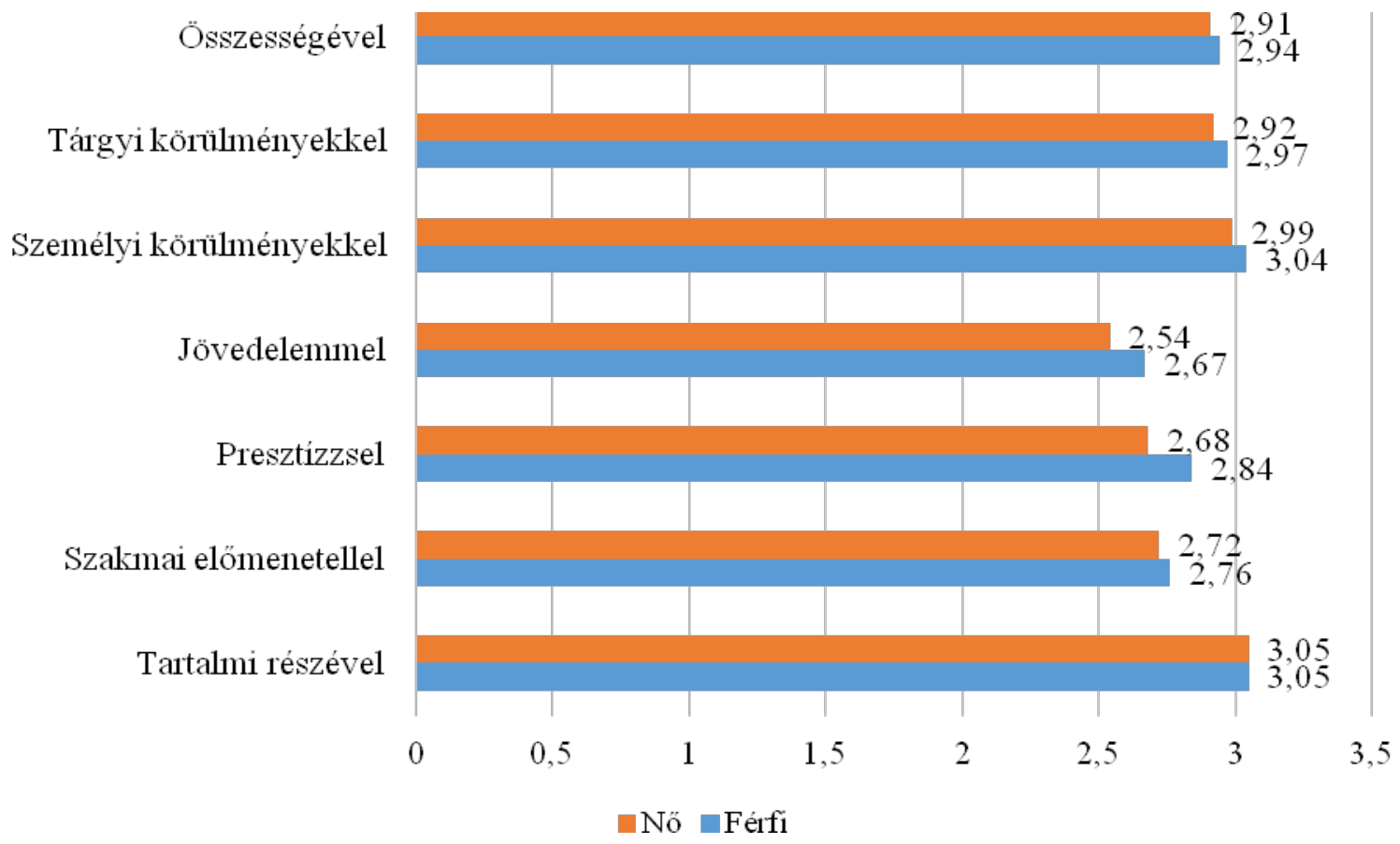

\section{Konklúzió}

Eredményeink alapján megállapíthatjuk, hogy a diplomával rendelkező fiatalok általános munkaerö-piaci helyzete kedvező. Azonban az is elmondható, hogy ezen belül is a magasabb végzettségi szint véd a munkanélküliséggel szemben. Hasonló megállapításra jutottunk az ún hagyományos (osztatlan, egyetemi, főiskolai) diplomával rendelkezők vonatkozásában is. 
A munkaerő-piaci részvétel statisztikailag releváns összefüggést mutatott a férfiak és a nők vonatkozásában. A nőkre jellemzőbb a munkaerő-piaci jelenlét megszakítása, mint a férfiakra. A munkaszerződések jellege és a gyermek jelenléte közötti összefüggés nem bizonyította előzetes feltevésünket. A gyermekesekre kevésbé jellemző az alkalmi, megbízási vagy határozott idejü szerződéssel való munkavégzés. A munkaerő-piaci hierarchiában elfoglalt hely vonatkozásában egyértelmü női hátrány rajzolódott ki. Ez összefüggésben van a munkaerő-piaci karrier megszakításával, mely szintén a nőkre jellemző inkább.

Összességében kijelenthetjük, hogy a prekariátus jelensége a vizsgált diplomások között is érvényesül. A prekár jelenségek jelentős nemek és végzettségi szint szerinti különbségeket mutatnak, ez igazolja a szakirodalmi állításokat is. A prekariátussal összefüggő hazai írások, elemző munkák köre igen szük. Eddig legjobb tudomásunk szerit Sík és Szeitl (2016) publikált e témában. Jelen írásunkkal a prekaritás jelenségének egy más típusú elemzésére vállalkoztunk a magasan kvalifikált fiatalok csoportja körében. További kutatási terveink között szerepel a prekariátus vizsgálatának mélyebb, átfogóbb, további szempontokat is figyelembe vevő, egyéb társadalmi csoportokra is kiterjedő, további összefüggéseket feltáró elemzésnek a lebonyolítása.

\section{IRODALOM}

Ferge, Zs. (2012): Prekariátus Magyarországon. Fordulat 19. 117-125. http://fordulat.net/pdf/19/F19 Ferge-interju.pdf

Kelemen, Zs., Rakovics, M. (2013): Prekaritás és habitus. Kérdések a prekariátusról, mint új osztályról és kategóriáról, Pierre Bourdieu társadalomelméletének tükrében. In: Hajdu et al. (szerk.): Kötetlen. Az ELTE Angelusz Róbert Társadalomtudományi Szakkollégium tanulmánykötete. ELTE ARTSZ, Budapest.13-22.

LaVaque-Manty, M. (2012): Hogyan bukkanhatunk elméleti fogalmakra a való világban? A prekariátus esete. Fordulat 19. 53.74.

Lazzarato, M. (2004): The Political Form of Coordination. http://eipcp.net/transversal/0707/lazzarato/en

Neilson, B., Rossiter, N. (2009): A prekaritás mint politkai fogalom. http://epa.oszk.hu/02100/02121/00017/pdf/EPA02121_fordulat_19_100-114.pdf. Letöltés 2017.07.28.

R. Fedor, A. (2015): Egyensúlyban? A munkaerö-piaci karriertől a familiarizmusig. Debrecen: Debreceni Egyetemi Kiadó, 2015. 252 p.

Róbert, P., Bukodi, E. (2002): Dual career pathways: The occupational attainment of married couples in Hungary. European Sociological Review 18/2, 217-232.

Szabó, F. (2017): Munkaerő-piaci helyzetkép Derecske járás területén élő fiatalok körében. A prekariátus új jelenségeinek vizsgálata. PhD disszertáció. Debreceni Egyetem, Kerpely Kálmán Doktori Iskola

Sik, E., Szeitl, B. (2016): A prekariátus mint munkaerö-piaci csoport. METSZETEK, 6 3-40.

Standing, G. (2012): The Precariat: The New Dangerous Class. Bloomsbury Academic.

Szépe, A. (2012): Prekariátus. Fordulat 19. 11-20.

Tordai B. (é. n.): A prekariátus fogalmáról. https://www.academia.edu/8358321/ 


\title{
AZ EGYETEM PEREMÉN. \\ A DE GYFK HALLGATÓI BÁZISÁNAK SZOCIOKULTURÁLIS HÁTTERE
}

\section{Szerzők:}

Bocsi Veronika

Debreceni Egyetem

Csercsa Zsuzsanna

Debreceni Egyetem

Csobay Vanessza

Debreceni Egyetem

Karmacsi Kitti

Debreceni Egyetem

Kreidl Edina

Debreceni Egyetem

Kőszegi Ildikó

Debreceni Egyetem

Pálfi Regina

Debreceni Egyetem

\section{Lektorok:}

Pusztai Gabriella

Debreceni Egyetem

Neveléstudományok Intézete

Engler Ágnes

Debreceni Egyetem

Neveléstudományok Intézete

Mező Ferenc

Eszterházy Károly Egyetem

Nemes Magdolna

Debreceni Egyetem

Első szerző e-mail címe:

bocsiveron@gmail.com

Bocsi Veronika, Csercsa Zsuzsanna, Csobay Vanessza, Karmacsi Kitti, Kreidl Edina, Kőszegi Ildikó, Pálfi Regina (2017): Az egyetem peremén. A DE GYFK hallgatói bázisának szociokulturális háttere. Különleges Bánásmód, III. évf. 2017/4. szám, 19-32. DOI 10.18458/KB.2017.4.19

\begin{abstract}
Absztrakt
Tanulmányunk alapját egy 2017-es hallgatói lekérdezés képezi, amelynek során a Debreceni Egyetem Gyermeknevelési és Felnőttképzési Karának másodéves nappali tagozatos diákjait kerestük meg kérdőívünkkel. Vizsgáltunk célja feltárni, hogy az országos és regionális jellemzőkhöz viszonyítva a hajdúböszörményi hallgatók milyen sajátosságokkal bírnak.

Eredményeink a kar hallgatói bázisának relatíve hátrányos helyzetére mutatnak rá (diplomás szülők alacsonyabb aránya, kistelepülésről érkezők magas rátája stb.), ugyanakkor kitapinthatókká válnak a belső, szakok között meghúzódó eltérések is, amelyek kapcsolatba hozhatók az egyes képzések szociokulturális hátterével, illetve a bemeneti követelmények eltéréseivel is.
\end{abstract}

Kulcsszavak: felsőoktatás, társadalmi egyenlőtlenségek, hallgatók 


\title{
Diszciplína: nevelésszociológia
}

\begin{abstract}
The ground of our study is an institutional reserach which refers to the University of Debrecen Faculty of Education for Children and Special Educational Needs. The respondents were second year full time students. Our aim was to reveal what features this faculty's students have if we compare our data to nationwide or regional empirical findings.

Our empirical findings have pointed out the disadvantageous features of our students (lower rate of parents with degree, higher rate of students from villages etc.). These phenomena can be explained with the special social background of the training courses, the criteria of the attendance and the geographic location of the institution.
\end{abstract}

Keywords: higher education, social inequalities, students

Disciplines: sociology of education

\section{BEVEZETÉS}

A tanulmány empirikus eredményei egy, a tanulmány szerzői által készített kutatás eredményein alapulnak. Célunk az volt, hogy a hajdúböszörményi diákok szociokulturális hátterét és jövőre vonatkozó pályaképét felmérjük. Vizsgálatunkat indokolta, hogy bár ismerünk pedagógushallgatókra vonatkozó kutatási eredményeket (például Pusztai, Bocsi és Kovács, 2015), illetve a DPR adatbázis tudományterületi bontásai is elérhetők (például: Veroszta 2016), mindez nem ad elég pontos képet egy olyan intézményröl, ahol a pedagógusképzésnek csak bizonyos szegmense jelenik meg (óvodapedagógusok képzés, csecsemö- és kisgyermeknevelők képzése), valamint a társadalomtudományi képzésekhez tartozó szociálpedagógus képzés. (Hajdúböszörményben a vizsgálat idején, tehát 2017 tavaszán ez a három alapképzés müködött. Mesterképzéssel a kar ekkor nem rendelkezett (várhatóan a 2017/2018-as tanév tavaszi szemeszterében indul a szociálpedagógia mesterszak). 2017 szeptemberétől gyógypedagógia alapszak indul a DE GYFK-n, ami a hallgatói összetételt előre láthatóan komoly mértékben fogja átalakítani.) Ugyanakkor a különbségek tudományterületenként is jelentősek. (Elég csak arra gondolni, hogy az „orvosés egészségtudományi képzések" kategóriája magában foglalja az ápolói képzést és az általános orvosképzést is.) Ezen kívül a kar helyzete speciális, hiszen a Debreceni Egyetemhez tartozik, ugyanakkor a képzések helyszíne Hajdúböszörmény. Mindezen tények magyarázzák tanulmányunk címét is. A tanulmány elméleti keretei az expanzió jelenségkörét, illetve a kar történetét és sajátosságait járják körül, míg az empirikus részek a hallgatói bázis sajátos szociodemográfiai jellegére fókuszálnak, illetve a jövőre vonatkozó szakmai terveket elemzik.

\section{A FELSŐOKTATÁS TÖMEGESSÉ VÁLÁSA}

Tanulmányunk elméleti részét az előző évek felsőoktatásban történt változásainak áttekintésével kezdjük. Véleményünk szerint erre azért van szükség, mert az expanzió jelenségköre alapvetően határozza meg az hasonló profilú intézmények és karok létszámát, oktatói és hallgatói és oktatói állományát, mint a Debreceni Egyetem Gyermeknevelési és 
Felnőttképzési Kara. Az ezredforduló utáni létszámbővülés majd a megtorpanás mind a demográfiai trendekbe, mind pedig az oktatáspolitikai változásokba beágyazott, a képzés jellege pedig a társadalmi mobilitás jelenségével fonódik össze.

A társadalmi egyenlőtlenségek és a felsőoktatás több szálon és módon fonódik össze, és az összefonódás nem a tömegessé váló felsőoktatási rendszer kialakulásával kezdődött. A felsőoktatás egyrészt összekapcsolódik az elit és a középosztály státuszörökítő technikáival olyan módon, hogy vagy a rendszer egésze, vagy pedig bizonyos szegmensek generálnak magasabb szociokulturális státuszt.

A felsőoktatás bővülésének és szükülésének ciklikus modellje Archer (1988) nevéhez kapcsolható. Ez alapján tudjuk, hogy a felsőoktatásban való részvételi arány ingadozik, s ez az arány a felsőoktatási rendszerek mintegy ideáltípusait adja. Más elméletek a felsőoktatási rendszerek földrajzi különbségeire hívják fel a figyelmet, s különböztetik meg az angolszász vagy a japán felsőoktatási modelleket (Hrubos, 1999).

A magyarországi helyzet számos speciális vonásának megértéséhez a hazai oktatáskutatók munkáit használhatjuk fel (Kozma, 2004; Hrubos, 2014; Polónyi, 2014). Az bizonyos, hogy az expanzió jelensége a 90-es években indult el sajátos politikai környezetben, a rendszerváltás után. Lefolyását oktatáspolitikai szándékok, az intézmények finanszírozásának kérdései és a társadalmi igények egyaránt alakították. A hallgatói létszámok az ezredforduló után tetőztek, majd stagnálás és csökkenés volt megfigyelhetö. Ennek indokai egyrészt demográfiaiak, másrészt oktatáspolitikai döntéseknek is az eredményei.

Az expanzió hatásai sokrétüek. Érintik a hallgatói összetételt, az egyetemeken folyó pedagógiai munkát, a tanítás módszertanának sajátosságait - a következmények pedig a campusok egészét átformálják. Fontos a diverzifikáció, amely a felsőoktatás egyes szegmenseinek a „távolodását” is jelenti. Ez a távolodás mind az intézmények presztízsében/státuszában, mind pedig a hallgatói bázis összetételében megfogható. Bizonyos szakmák és képzések az értelmiségivé válás első lépcsőfokát jelenthetik egy intergenerációs mobilitás során, míg mások a felső középosztály újratermelését biztosítják. Elemzésünk terepe, a DE GYFK tipikusan az első kategóriába sorolható.

Az expanzió a diákok szociális összetételét is megváltoztatta. Megnövekedett az ún. „nem tradicionális” hallgatók aránya (Pusztai, 2011; Engler, 2014, Ceglédi és tsai, 2015), akik nem középosztálybeli háttérrel, nem értelmiségi családból, sokszor gyermekvállalás után iratkoznak be a képzésekre, s sok esetben etnikai vagy nemzeti kisebbségek tagjai. (A „nem tradicionális hallgatók" jelen tanulmányban használt értelmezése leginkább a Pusztai Gabriella (2011) által használt fogalommal rokonítható (a nemzetközi szakirodalomban a fogalom tágabb értelmezést nyer.) A nem tradicionális hallgatók aránya minden bizonnyal összefügg a felsőoktatás diverzifikálódásával, bár az intézmények egy típusában valószínüleg mindig nagyobb arányban képviseltették magukat. Oktatástörténeti kutatások kimutatták, hogy már a századelő és a Horthy-kor felsőoktatási rendszerében is megfogható volt a kispolgári, paraszti- vagy munkásszármazású fiatalok magasabb aránya például az agrárképzésben vagy a papi/lelkészi pályán (Nagy, 2012). S bár a Kádár-rendszer támogatta a munkás-paraszt származásúak felsőoktatásba kerülését (ennek módszerei és volumene változott a szocializmus alatt), az alacsonyan tartott keretszámok és a bekerülési feltételek erősen szürték az egyetemre-föiskolákra belépők körét (Ladányi, 1994).) Ez a zártabb rendszer még a kilencvenes évek első felében is jellemző volt, amikor is a hetvenes években születettek nagyobb létszámú kohorsza tovább nehezítette a felsőoktatásba való bejutást (1. ábra). 
1. ábra: A felsöoktatásba jelentkezettek és felvettek száma 1990 és 2016 között (föben megadva forrás: KSH (Net1) adatai alapján a Szerzök szerkesztése)

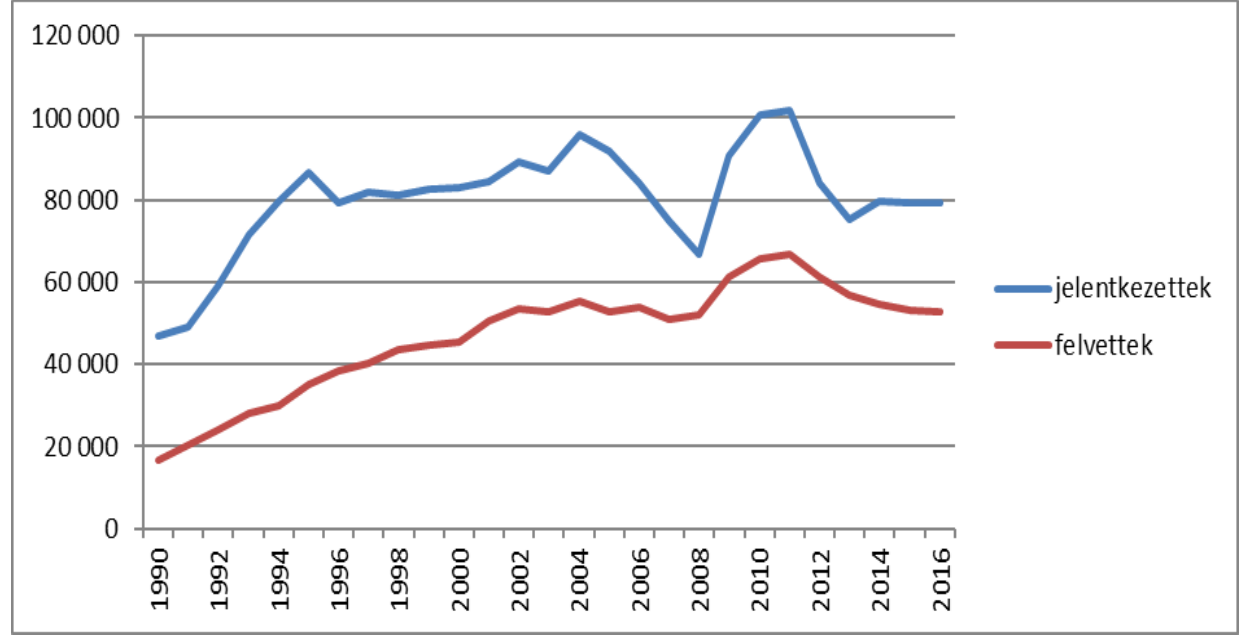

Az expanzió megtorpanását elöször a levelező tagozatos hallgatók arányának és létszámának csökkenése jelezte. A nappali tagozatos diákok létszáma is stagnálni kezdett, aminek elsősorban demográfiai okai voltak. A tanulástól való „eltávolodást” azonban más mutatók is jelzik: a Magyar Ifjúság 2012 adatbázisában a későbbiekben tanulni vágyók aránya is csökkenést mutat, nem csupán a hallgatók aránya (Bocsi, 2016). A tanulástól való eltávolodás jelenségét a munkaerö-piaci változások is indukálhatják - a diploma nélkül, szakképzettséggel betölthető állások egyfajta elszívó hatást gyakorolnak, s ennek végpontjai gyakran a külföldi munkaerö-piacra vezetik a fiatalokat. Szintén fontos kontextust képez az egyes diplomák munkaerőpiacon történő értékesíthetősége.

Kérdés, hogy az expanzió megtorpanása hogyan hat majd a hallgatói összetételre. Egyelöre nem tudni, hogy tapasztalhatunk-e majd egyfajta visszarendeződést vagy jelenlegi szociális összetétel további megléte prognosztizálható. A 2. ábra szemlélteti a hallgatói létszámok csökkenését.

2. ábra: Az oktatók, a levelezö és a nappali tagozatos diákok létszáma 1990-töl (föben megadva, forrás: KSH alapján (Net2) a Szerzők szerkesztése)

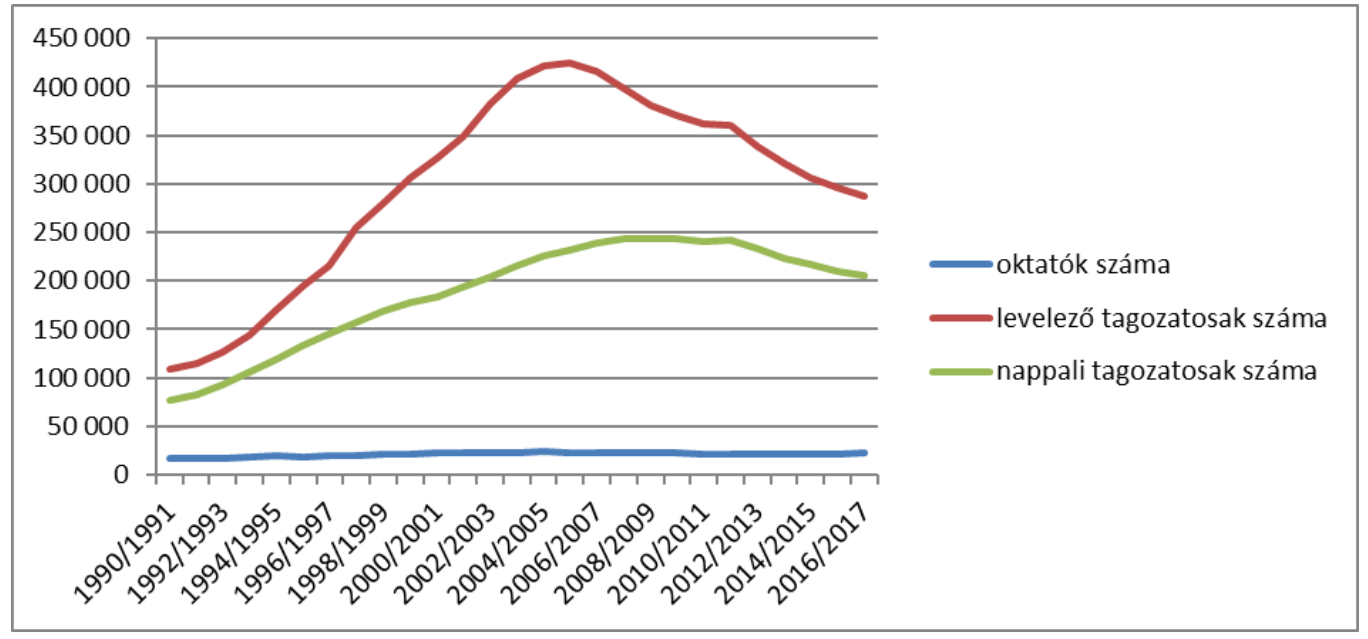


Az ábráról az is leolvasható, hogy a jelenlegi helyzetben még mindig magasabb az egy oktatóra jutó hallgatók száma, mint a kilencvenes években volt - mindez a hallgató-oktató kapcsolatokra nyomja rá a bélyegét, és ezáltal átalakítja az intézményi hatások müködési mechanizmusát. Látható az is, hogy az oktatói létszámok az expanzió kezdetétől annak lecsengéséig nem változtak - mindez az oktatók leterheltségét is nagy mértékben alakította. A hallgató-oktató kapcsolatok meglétének, sürüségének és mintázatainak a felsőoktatáskutatás kiemelten fontos jelentőséget tulajdonít, hiszen ezen keresztül nem csupán az intézményi integráció valósul meg, hanem a származási hátrányok csökkentésében is szerepet játszik (Pusztai, 2011).

\section{ÚJ EGYENLŐTLENSÉGEK?}

Az a tény, hogy bizonyos intézmények és képzések presztízse eltérő, illetve az oda járó hallgatók társadalmi háttere sajátos, közhelynek tekinthető a felsőoktatás kutatásában. Ugyanakkor a bejutási esélyek, a hallgatói populáció jellemzői folyamatosan változnak, bizonyos oktatáspolitikai döntések pedig formálják az egyes képzések társadalmi hátterét (például az emelt szintü érettségi feltételének hiánya bizonyos képzési területeken).

Azt már láttuk, hogy a hallgatói létszámok és arányok az utóbbi tíz évben csökkentek. A Magyar Ifjúság kutatások adatait összevetve (2004, 2008 és 2012) az a trend látható, hogy a felsőoktatás egésze 2012-ben nem mutatta az felsőoktatási esélyegyenlötlenségek csökkenésének jeleit (3. ábra). Miközben 2008 és 2012 között az érettségizettek száma nőtt a kutatás 8000-es mintájában, a hallgatók aránya az érettségizetteken belül 2012-re 21,7\%-ra csökkent a korábbi $25 \%$-os értékröl.

3. ábra: Az alacsony iskolai végzettségü és a diplomás apák gyermekeinek aránya a hallgatók között (Ifjúság 2004, 2008 és 2012 alapján, Forrás: Bocsi, 2016, 157. o.)

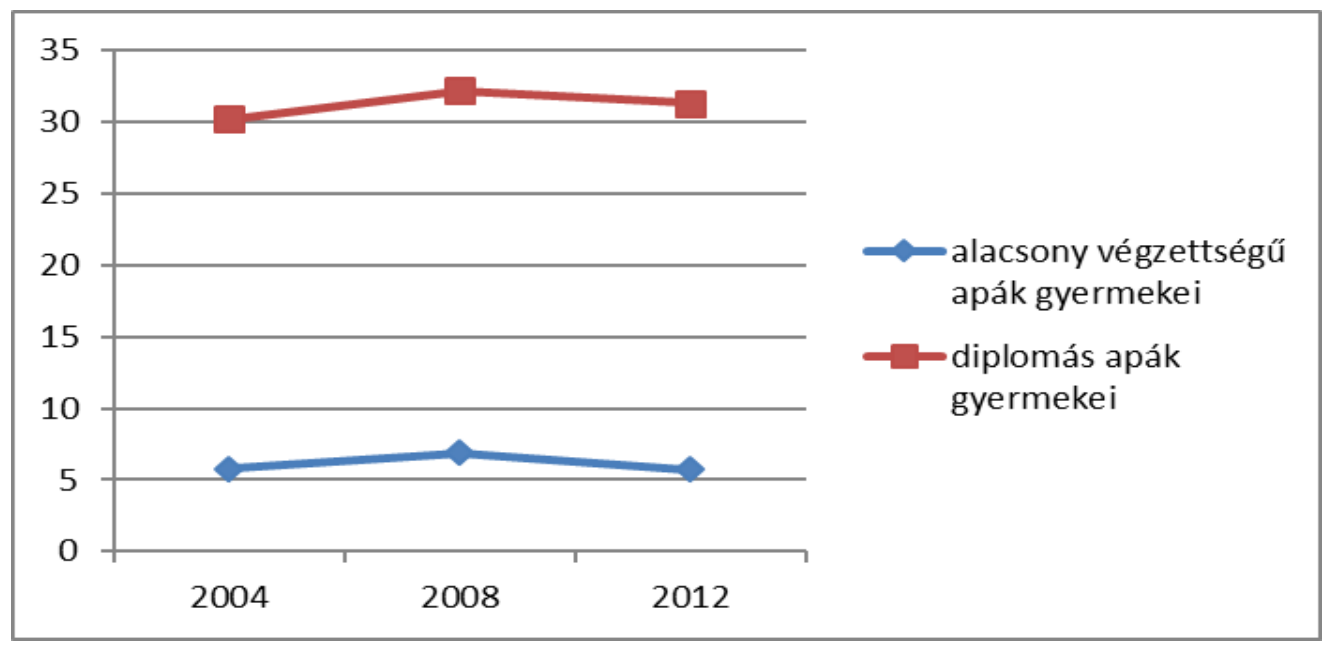

A hagyományos főiskolai és egyetemi képzések átalakulásával, illetve a bolognai rendszer bevezetésével az hallgatók társadalmi hátterének eltéréseit a képzési szintek szerint vizsgálhatjuk. 2015-ben az Oktatási Hivatal adatai alapján hátrányos helyzetért többletpontot kapott és felvett hallgatók felülreprezentáltak voltak az alapképzésekben, s mindössze 6,4\%- 
uk vett részt mesterképzésen és 7,7\%-uk osztatlan képzésben. (Net3) A felvételt nyert hátrányos helyzetü diákok százalékos megoszlását a 4. ábra szemlélteti. A hátrányos helyzetü hallgatók a gazdaságtudományi és pedagógusképzésekben vesznek részt a legnagyobb arányban. Hegedűs (2016) a hátrányos helyzetűek felsőoktatási jelenlétének területi dimenzióját vizsgálja, s jut arra a megállapításra, hogy ezen hallgatók bizonyos intézményekben (például a Debreceni Egyetemen) felülreprezentáltak. A 2013. és 2014. évi statisztikákat elemezve pedig azt állapítja meg, hogy a hallgatói populációban a hátrányos helyzetüek aránya csökkenő trendet mutat.

4. ábra: A hátrányos helyzetü hallgatók képzési területenként (százalékos arányok, forrás: Oktatási Hivatal adatai alapján (Net3) a Szerzők szerkesztése)

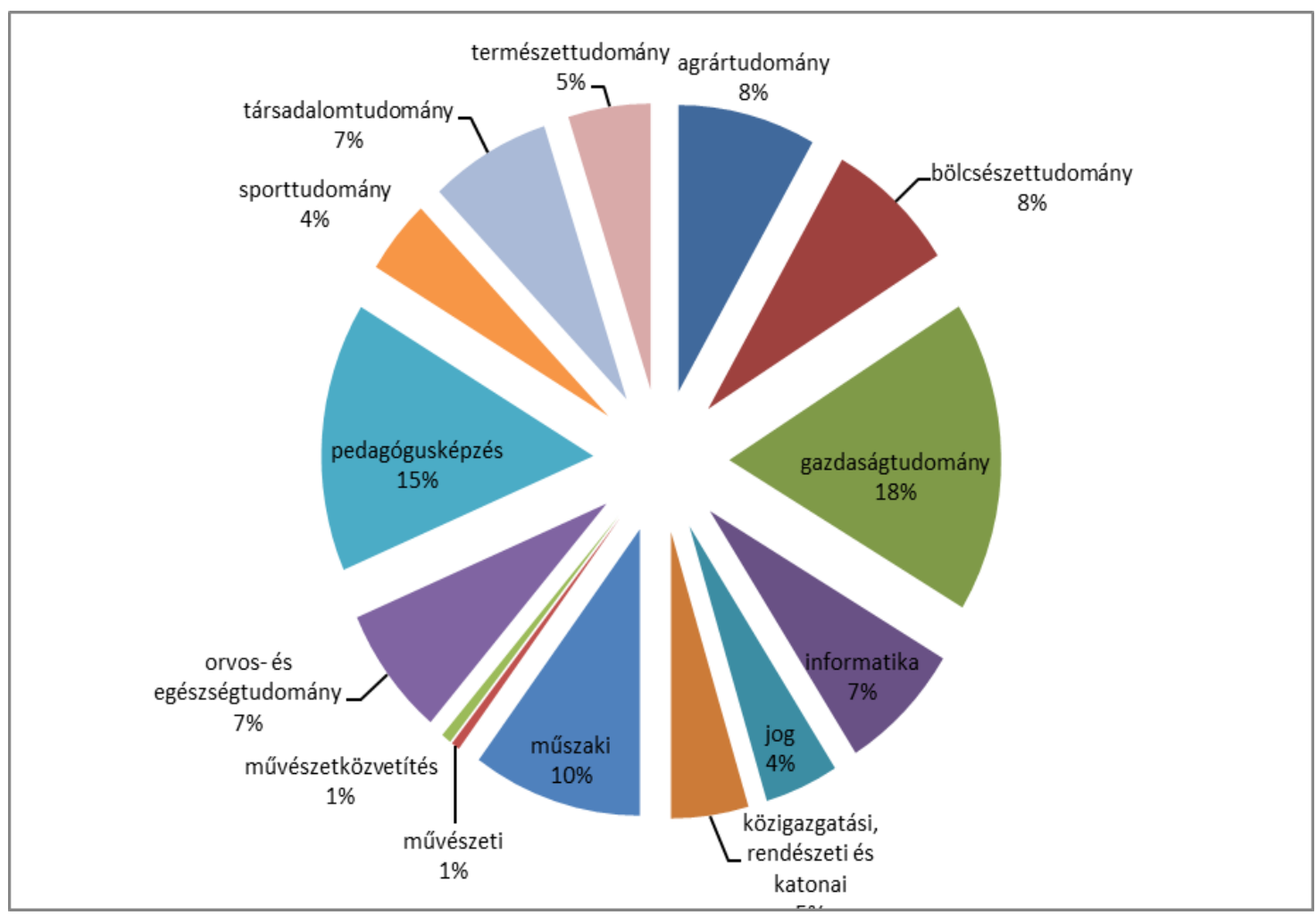

A DPR segítségével a szülők iskolai végzettségét képzési területenként is elemezhetjük. A kapott adatok ebben az esetben is a pedagógusképzések sajátos helyzetét támasztják alá, míg a másik póluson a jogi képzést találhatjuk (5. ábra). A végzett pedagógusok majdnem húsz százaléka érkezik olyan családból, ahol a szülői háttér alapfokú végzettséggel jellemezhető. 
5. ábra: Az alacsony végzettségü szülövel bíró hallgatók aránya képzési területenként (százalékban megadva, forrás: a DPR 2014 (Net3) a Szerzök szerkesztése)

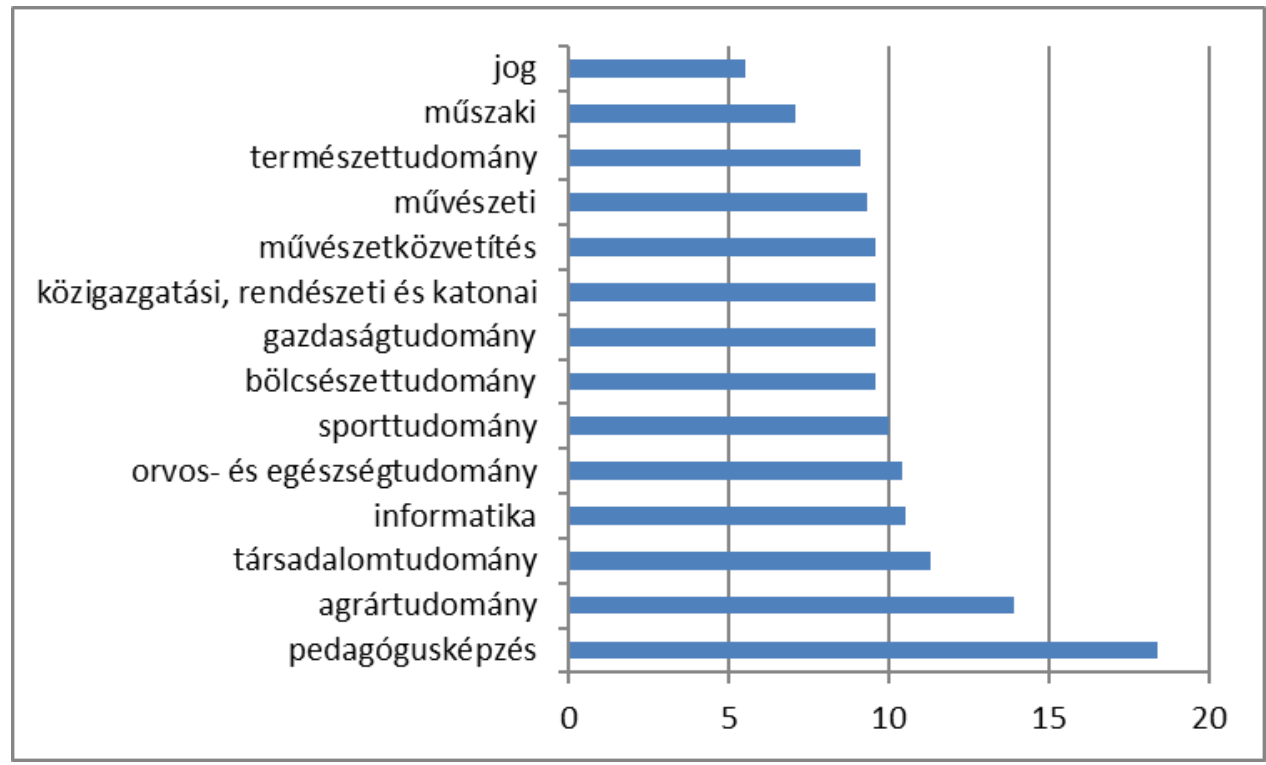

Összességében azt mondhatjuk, hogy felsőoktatás jelenlegi rendszerében az egyenlőtlenségek számos változó mentén vizsgálhatók - fontosak lehetnek a kulturális tőke különböző mutatói vagy a gazdasági mutatók. Az általunk bemutatott ábrák az alapképzés és a pedagógusképzés speciális helyzetét húzzák alá. Az osztatlan képzések és a mesterszakos képzések diákjainak családi háttere kedvezőbb mintázatokat mutat. Láthattuk, hogy a pedagógusképzés sok esetben az elsőgenerációs értelmiségképzés csatornáját jelenti, ami kihat az ilyen profillal bíró intézmények és karok klímájára, az oktató-hallgató kapcsolatokra és a tanítási-tanulási módszerek egészére is. A pedagógusképzésben résztvevők számát ugyanakkor nem csupán az expanzió, hanem a pedagóguspálya presztízse, a bekerülési feltételek és a tanárképzés egész struktúrája is alakítja. A későbbi tanárok, tanítók és óvodapedagógusok szociális háttere is fontos tényező, hiszen a tanári hivatásról alkotott kép és a későbbi gyakorlatok kapcsolatban állnak a demográfiai háttértényezőkkel.

\section{KUTATÁSUNK SZÍNHELYE, A DEBRECENI EGYETEM GYERMEKNEVELÉSI ÉS FELNÖTTKÉPZÉSI KARA}

Az elemzésünk helyszínét adó campus óvónőképző intézetként 1971-től müködik. Kezdetben a Nyíregyházi Tanárképző Főiskolához tartozott, majd a hetvenes évek közepén vált önállóvá. 1986 és 1990 között a Debreceni Tanítóképző Intézet része, majd egy rövid önálló periódus után az egyetemek integrációjának során az újonnan megalakuló Debreceni Egyetem egyik karaként folytatta müködését. Képzési profiljában pedagógiai és társadalomtudományi képzések jelennek meg (jelenleg: óvodapedagógus, csecsemő- és kisgyermeknevelö, szociálpedagógus képzés folyik, korábban müvelödésszervező és andragógia szakon képeztek hallgatókat, 2017 szeptemberétől pedig gyógypedagógia képzés indul).

A kar speciális helyzetét nem csupán az adja, hogy a képzések nem debreceni székhellyel zajlanak, hanem az is, hogy az intézmény korábban nappali tagozatos mesterszakkal nem rendelkezett (levelező tagozaton egy másik karral együtt emberi erőforrás tanácsadó képzés 
folyt). Ez a helyzet elöre láthatóan 2018 februárjától fog megváltozni, amikor is a tervek szerint szociálpedagógia mesterszak indul. Az intézményben jelentős a szakirányú továbbképzéseken és szakvizsgás képzéseken tanulók száma is. A kar hallgatói létszáma 2017 tavaszán 1193 fö volt, és 39 főállású oktató dolgozott az intézményben. A kínált képzések inkább gyakorlati, s kevésbé elméleti jellegüek. A hallgatói létszám a karon az expanzió miatt az ezredforduló után érte el a legmagasabb értékét, majd nagyobb mértékủ csökkenést mutatott. Az utóbbi években azonban - leginkább a pedagógiai képzések bekerülési feltételei, illetve a pedagógus életpályamodell bevezetése miatt emelkedett (ez utóbbi tényező a levelezős hallgatók számát emelte meg.).

Egy kar hallgatói összetételét sok tényező befolyásolhatja. A kínált szakok kapcsán látnunk kell, hogy azok általában az elsőgenerációs értelmiségképzés színhelyei, s mint ilyen, nagy szerepet játszik a generációkon átívelő társadalmi mobilitás folyamatában. A karon müködik egy roma szakkollégium, amelynek kb. 30 roma fiatal a tagja. Láthatjuk tehát, hogy mindezen tények a „nem tradicionális” hallgatók magasabb arányát vetítik előre.

Ezen kívül ki kell térnünk a földrajzi elhelyezkedés következményeire is. Bár a Debreceni Egyetem a hazai egyetemek közül a magasabbra rangsorolt intézmények közé tartozik (például: https://www.topuniversities.com/university-rankings/eeca-rankings/2016), hallgatói bázisa a fővárosi intézményekhez képest hátrányosabbnak tekinthető. A falusiak aránya magasabb, a szülők iskolai végzettsége alacsonyabb (Pusztai, 2011). A diákok jelentős része az ország keleti és északi régióiból érkezik, illetve a határon túli magyarság adja a hallgatói bázis egy részét (ahol a tőkefajtákkal való ellátottság szintén szerényebb). A Debreceni Egyetem jelenlegi 14 kara közötti eltérések jelentősek, s ez mind státuszban (Fónai, 2009), mind szociokulturális mutatókban kifejezhető. Mivel a Gyermeknevelési és Felnőttképzési Karra vonatkozóan nem voltak pontos ismereteink, úgy döntöttünk, hogy jelen kutatás keretein belül próbáljuk feltárni a hajdúböszörményi hallgatói sajátosságokat.

\section{MÓDSZER}

2017 tavaszán hat hallgató szabadon választható óra keretében vett részt egy módszertani kurzuson. Azt tüzték ki célul, hogy egy rövid kérdöív segítségével a kar másodéves nappalis hallgatóit mérik fel. Teljes körü lekérdezést terveztünk az alacsony létszám miatt (105 fö). A hallgatók az elöadások és szemináriumok alkalmával érték el másodéveseket. Az egyéni tanrenden tanulók és az egyéb hiányzók miatt 74 fö töltötte ki a kérdőívet. A lekérdezést, a kódtábla készítését, a rögzítést és az elemzést a hallgatók végezték el. Nagyon fontos, de inkább jelzésértékü eredménynek tekintjük a szakok közötti eltérések vizsgálatát. Ennek oka, hogy a nappali tagozaton szociálpedagógiát tanulók száma nem érte el a húsz föt. Elemzésünk során éppen ezért csupán átlagokat és százalékos megoszlásokat használtunk fel.

A kérdőív során egyrészt a hallgatók szociokulturális hátterét igyekeztünk feltérképezni (szülök iskolai végzettsége, lakóhely típusa, anyagi helyzet, könyvek száma), másrészt olyan kérdéseket tettünk fel, amelyek a jövőbeni munkavégzésükre vonatkoznak (milyen jellegü intézményekben szeretnének dolgozni).

Elemzésünk során az alábbi hipotéziseket fogalmaztunk meg:

1. hipotézis - feltételezzük, hogy a „nem tradicionális” hallgatók adják a DE GYFK hallgatói bázisának a többségét. Ezen hallgatók aránya (nem diplomás szülők, falusi lakóhely) az egyes karok esetén is eltér. (Itt a szociálpedagógia szakosok előnyösebb helyzetét prognosztizáljuk, amit az emelt szintü érettségi, illetve a korábban bemutatott tudományterületi összefüggések indokolnak.)

2. hipotézis - a DE GYFK diákjainak szociokulturális helyzete minden dimenzióban, ahol összehasonlítási alapunk van akár regionális, akár pedig országos adatokhoz, lemaradásokat mutat. 


\section{EREDMÉNYEK}

\section{A szociokulturális háttér mutatói}

Első lépésben a diákok szociokulturális hátterét vizsgáljuk meg. A településtípus felmérése során a diákoknak a föváros/megyeszékhely, kisebb város, illetve a falu/tanya válaszlehetőségek közül kellett választani. Az, hogy a települési lejtő ténylegesen is hátrányt generál az oktatás során, vagy pedig a falvak sajátos társadalmi összetétele okozza pl. a falusi gyermekek alacsonyabb teljesítményét, nem pontosan eldönthető kérdés, kutatások azonban utalnak arra, hogy a magas iskolai végzettségü szülők a gyermekeik iskolai karrierjét a falvakból is el tudják indítani (Gazsó, 2008). A DE GYFK hallgatóinak 34\%-a él falun, 43\%a kisebb városban, és 23\%-a fóvárosban vagy megyeszékhelyen (ami értelemszerüen ebben az esetben Debrecent jelenti). Ha mindezt a 2012-es Magyar Ifjúság adatbázishoz hasonlítjuk, akkor a böszörményi diákok falusiasabb, kisvárosi jellege látható az országos adatokhoz viszonyítva. (6. ábra). (Az Magyar Ifjúság 2012 adatbázissal Bocsi Veronika dolgozott. A használat lehetőségét köszönjük a Kutatópontnak.) A százalékos eloszlásainkat a Debreceni Egyetem 2012-es adataihoz viszonyítva a falusiak és a kisvárosiak magas arányát mutathatjuk ki. (HERD kutatás: Higher Education for Social Cohesion Cooperative Research and Development is a Cross-border Area. Regisztrációs szám: HURO/0901/253/2.2.2. Vezetö: Prof. Dr. Kozma Tamás.)

6. ábra: A DE GYFK és a Magyar Ifjúság 2012 nappali tagozatos almintájának településtípus szerinti megoszlása ( $N=74$ és 766, százalékban megadva, forrás: a Szerzők)

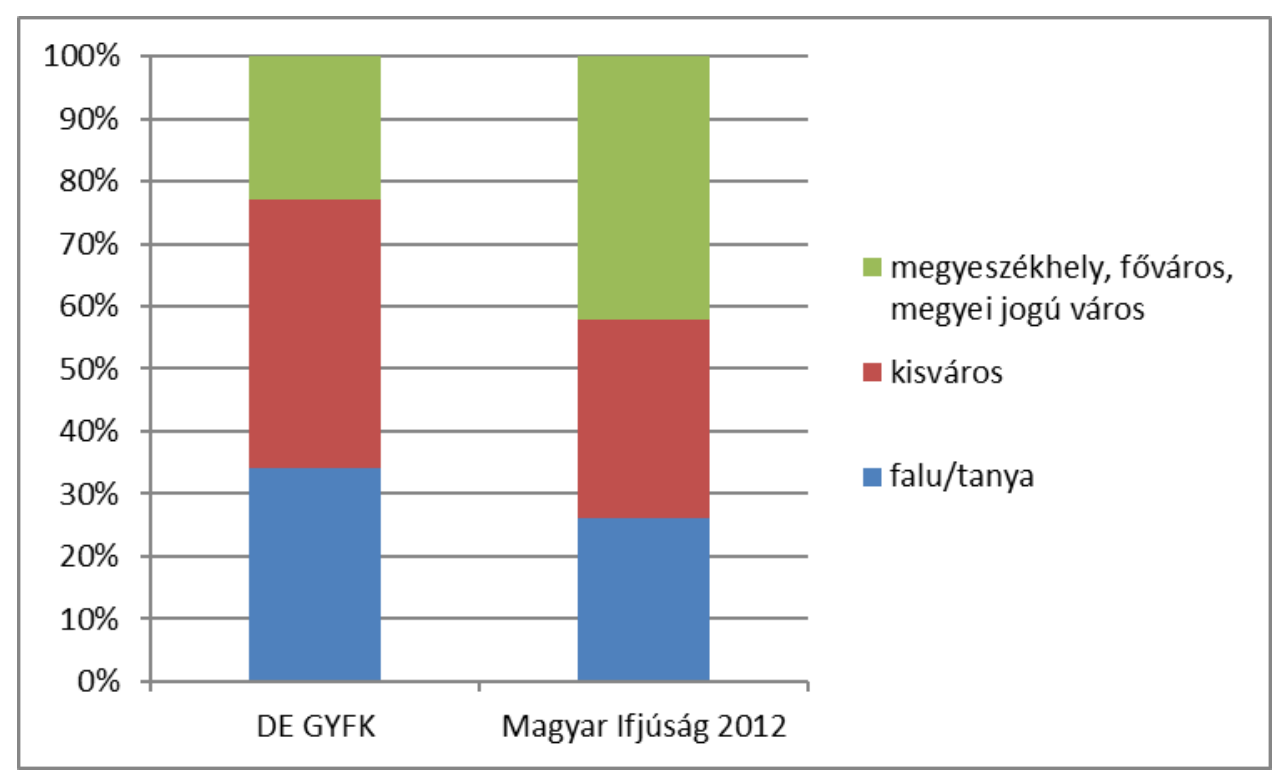

A szülők iskolai végzettségét a 7. ábra szemlélteti. Az ábráról egyrészt leolvasható, hogy az édesanyák és az édesapák iskolai végzettsége között igen komoly különbség rajzolódik ki. Az apák több mint 50\%-a érettségivel sem rendelkezik, általános iskolai végzettsége pedig kb. $12 \%$-nak van. Az egyetemi végzettség aránya mind a két nemnél 10\% alatt marad, azonban az édesanyák esetében a föiskola is jelentős (majdnem 20\%-os) kategóriát képvisel. A Magyar Ifjúság 2012-es adatbázis nappali tagozatos diákjainak esetében a diplomás anyák aránya kevéssel, de meghaladja a 30\%-ot, míg az apák esetében ez a mutató 29,3\%. A nyolc 
általánost végzett apák aránya a böszörményi mintában négyszerese az országos adatoknak. A másodéves böszörményi diákok közül három hallgató érkezett olyan családból, ahol az apa és az anya is diplomával bírt, olyan hallgatója azonban nem volt az intézménynek ezen az évfolyamon, ahol mind az apa, mind az anya egyetemi végzettséggel rendelkezett volna.

7. ábra: A szülö iskolai végzettsége százalékban megadva (DE GYFK 2017, N=74, forrás: a Szerzök szerkesztése)

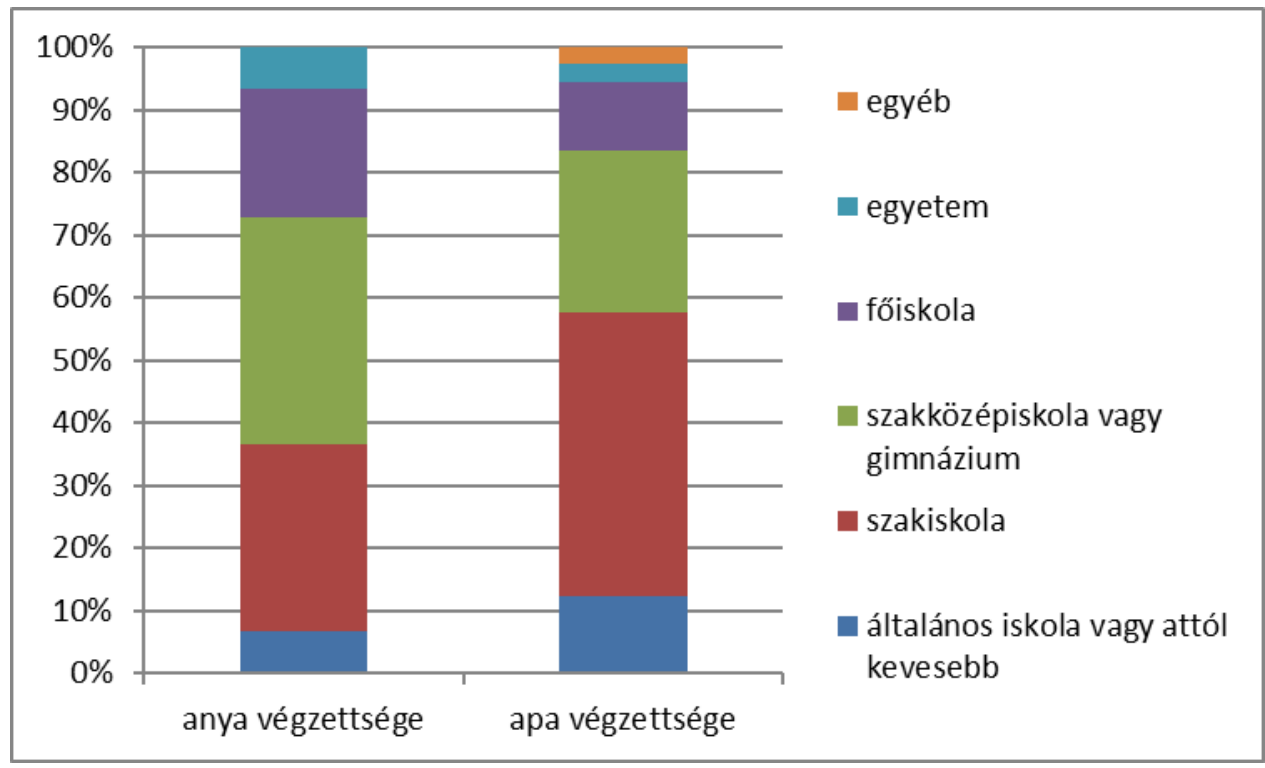

A háztartásban fellelhető könyvek számát a böszörményi diákok átlagban 190-re becsülték, ez a szám a Magyar Ifjúság 2012 országos almintájában 290 volt.

A böszörményi diákok szociokulturális hátteréről összességében azt mondhatjuk, hogy az elmarad mind az országos, mind pedig a DE egészének mutatóitól. (Az anyagi tőkével való ellátottságot csak a belső, szakok közötti összehasonlításra használjuk, mivel az általunk alkalmazott kérdésblokk nem egyezett más kutatások kérdésblokkjaival.)

\section{A szakok közötti eltérések vizsgálata}

A szakok közötti eltérések véleményünk szerint pontosíthatják azokat az összefüggéseket, amelyeket a tudományterületenkénti elemzések már feltártak. Ugyanakkor az intézmények földrajzi elhelyezkedése is számít, $\mathrm{s}$ a szociokulturális háttér mintázatai intézményenként is eltérőek. A szakok eltérései többek között a képzések jellegével és a bemeneti követelményekkel magyarázhatók. Az azonban kétségtelen, hogy a hallgatói lét sok területét befolyásolja a szociokulturális háttér (például az eredményességet, a tudományos teljesítményhez való viszonyt, a tanulási ráfordításokat - az összefüggések azonban nem lineárisak).

Elemzésünkben három szak, az óvodapedagógia, a csecsemö- és kisgyermeknevelö, illetve a szociálpedagógusok mutatóit hasonlítjuk össze. Jelen alfejezet eredményeinek felhasználhatóságát csökkentik az alminták alacsony elemszámai. Ezeket ugyanakkot egy sikeres teljes körü lekérdezéssel sem tudtuk volna jelentősen megemelni (a szociálpedagógia nappali képzés második évfolyamának létszáma összesen 16 fö). A szakok almintái a következőképpen alakultak: óvodapedagógia 41 fö, csecsemő- és kisgyermeknevelő 21 fö, szociálpedagógia 12 fö. A kapott adatok egy sajátos, az előzetesen elvárt rajzolatot mutatják. Ha az apák iskolai végzettségét vetjük össze, akkor a csecsemő és kisgyermeknevelő szakos diákok speciális helyzetét állapíthatjuk meg - az apák több mint 60\%ának érettségije sincsen. A diplomás apák aránya a szociálpedagógusoknál a legmagasabb (8. ábra). 
8. ábra: Az apák iskolai végzettsége szakonként (DE GYFK 2017, N=74, százalékban megadva, forrás: a Szerzők szerkesztése)

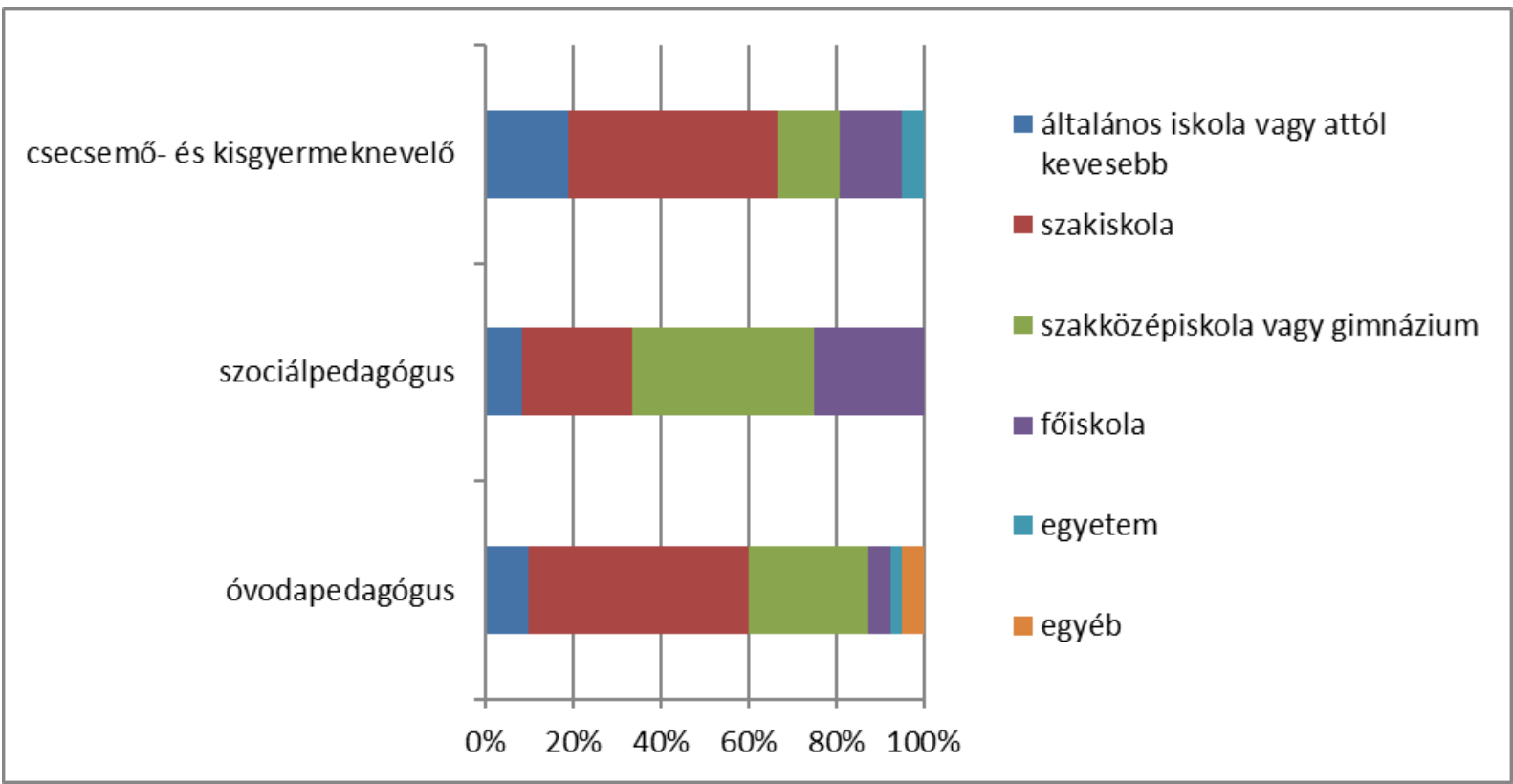

Más háttérmutatók vizsgálata esetén is azt láthatjuk, hogy a szociálpedagógusok helyzete a legkedvezőbb, éppen úgy, ahogyan a családi könyvtár nagysága, illetve a gazdasági tőke indexének esetében is tapasztalható. A szociálpedagógusok esetében a családi könyvtár nagysága megegyezik az országos adatokkal (290 db), míg a másik két szak diákjai szerényebb könyvállománnyal rendelkeznek (óvodapedagógusok - 208 darab, csecsemő- és kisgyermeknevelők - 116 darab). Az anyagi tőke indexét tartós fogyasztási cikkekből képeztük. A kérdőívben az alábbi tartós fogyasztási cikkek szerepeltek: családi ház/lakás, telek/nyaraló, személyautó, számítógép/notebook, tablet/IPhone, klíma, mosogatógép. A válaszlehetőségek a következők voltak: nincs a háztartásban, egy van, több is van. Az index képzése során az „egy van” válasz egyes értékkel szerepelt, a „több van” pedig kettessel. A kapott mintázat megegyezik a korábbi, szakok közötti rajzolatokkal, ugyanakkor az óvodapedagógusok és a csecsemő- és kisgyermeknevelők között a distancia jóval kisebb (szociálpedagógusok - 7,2 az index értéke, óvodapedagógusok - 5,8, csecsemő- és kisgyermeknevelők - 5,7).

\section{A szakmai tervek vizsgálata}

A szakmai tervek vizsgálata során a 2014-es Szaktárnet kutatás adataihoz viszonyítottuk a hallgatók elképzeléseit. (Szaktárnet - Szakmai szolgáltató és kutatást támogató regionális hálózatok a pedagógusképzésért az Észak-alföldi régióban” c. projekt (TÁMOP 4.1.2.B.2-13/1). Vezető: Dr. Tóth Zoltán PhD. habil.) A Szaktárnet DE CHERD által elvégzett lekérdezés kérdésblokkjára építettük fel saját kérdésblokkunkat. A diákoknak arra a kérdésre kellett egy ötfokozatú skála segítségével választ adniuk, hogy milyen intézményekben vagy térségekben dolgoznának szívesen. Itt számolnunk kell azzal, hogy bizonyos itemek kevésbé relevánsak (például a „gyakorló iskola” itemére gondolunk), ugyanakkor az összevethetőség kedvéért megtartottuk azokat. Az észak-alföldi régió pedagógushallgatóinak és a DE GYFK diákjainak összevetését a 9. ábra mutatja be. A leginkább érdekes eltérések az SNI-s vagy kisebbségi gyermekekkel való munka esetében mutatkoznak meg, akik felé, mint láthatjuk, a DE GYFK hallgatói elkötelezettebbek. 
9. ábra: A tervezett munka helyszine az észak-alföldi régió pedagógushallgatóinak körében és a DE GYFK-n ( $N=307$ és 74, ötfokozatú skálával mérve) (A Szaktárnetes adatok forrása: Bocsi és Rákó, 2015 felhasználásával a Szerzök szerkesztése)

Láthattuk, hogy a kar hallgatói között felülreprezentáltak a kistelepülésről érkezők, míg a beiskolázási körzetek az ország hátrányosabb helyzetü járásai közé tartoznak. Érdemes tehát egy pillantást vetni arra, hogy a munkavégzésük tervezett helyszínei milyen sorrendet mutatnak. A célként megjelölt helyszínek leginkább a nagyvárosok és a fejlett régiók irányába (10. ábra). Ha a sorrendet az észak-alföldi régió pedagógushallgatóihoz viszonyítjuk (Bocsi és Rákó, 2015), akkor csekélyebb eltéréseket tapasztalhatunk. A legkomolyabb eltérés az SNI-s gyermekeket integráltan nevelö intézmények esetében tapasztalható, amely a pedagógushallgatók mintájában az utolsó előtti helyen szerepel, a DE GYFK hallgatóinál azonban a középmezőnyben kap helyet.

10. ábra: A munkavégzés tervezett helyszinei (DE GYFK 2017, N=74, ötfokozatú skálával mérve, forrás: a Szerzök szerkesztése)

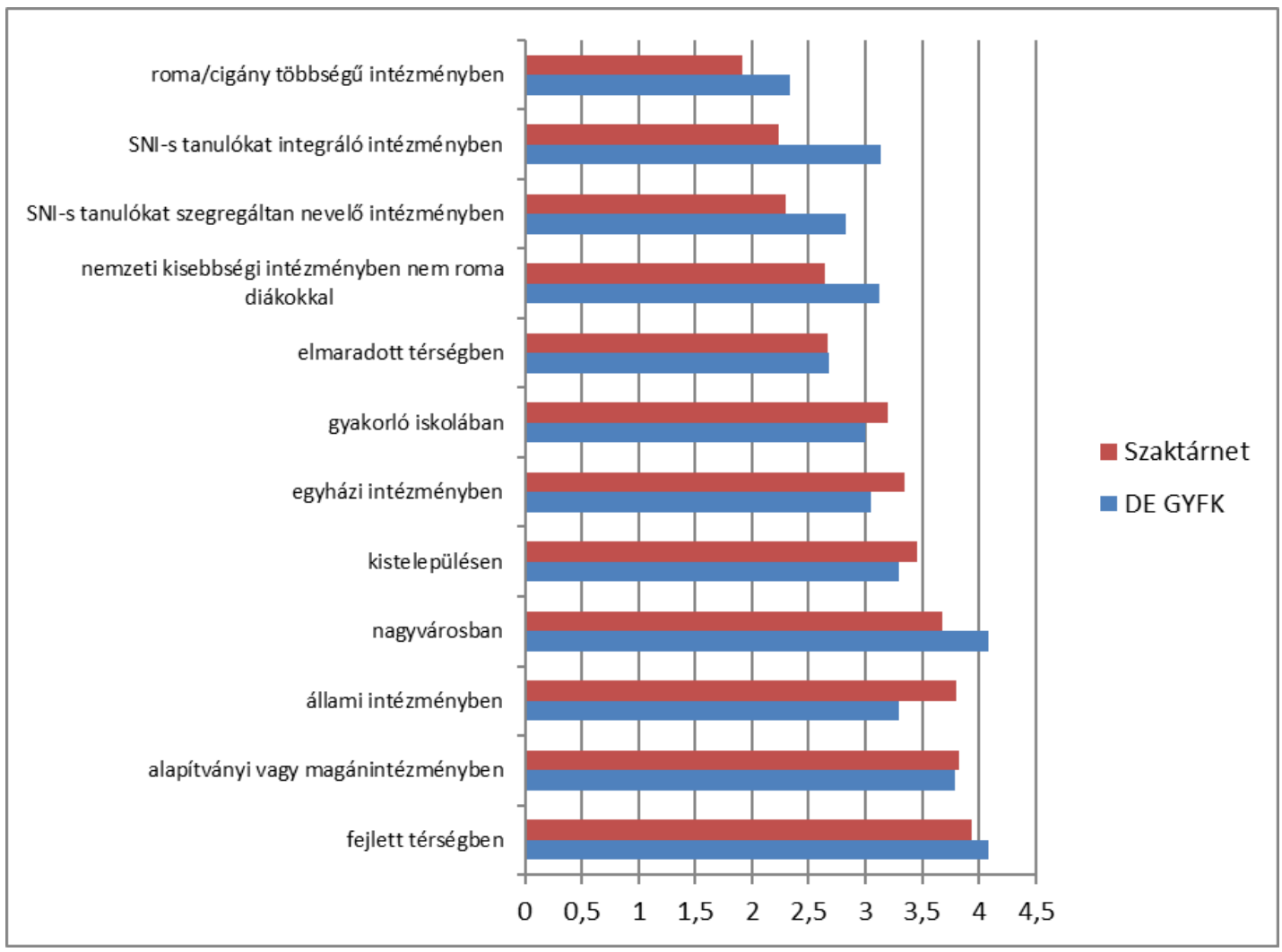

\section{Összegzés}

Tanulmányunkban arra vállalkoztunk, hogy a Debreceni Egyetem Gyermeknevelési és Felnőttképzési karának hallgatói bázisát vizsgáljuk meg. Elemzésünk fó oka az volt, hogy bár ismertek a felsőoktatásban megfogható egyenlőtlenségekkel foglalkozó elemzések, melyek lehetnek regionálisak vagy a képzési szintekben megfoghatóak, de ezek segítségével pontos kép nem rajzolható meg egy olyan kar hallgatói populációjáról, amely a felsőoktatás hazai rendszerén belül is „hátrányos helyzetünek" tekinthető.

Hipotéziseinket is ennek fényében fogalmaztuk meg. Az első hipotézisünk arra vonatkozott, hogy a kar hallgatóinak többségét a „nem tradicionális” hallgatók adják - ez a hipotézisünk teljesült, hiszen 
láthattuk, hogy a szülök iskolai végzettségének tekintetében igen alacsony volt azoknak az aránya, akik magasabban kvalifikált szülők gyermekeként érkeztek az intézménybe, s a falusi diákok is felülreprezentáltak voltak. A karon belüli eltérésekkel kapcsolatban elmondható, hogy a bemeneti követelmények és tudományterületi hovatartozás alapján vártunk egy olyan mintázatot, amelyet az elemzésünk is alátámasztott. Legkedvezőbb helyzetben a szociálpedagógus hallgatók vannak, míg a csecsemő- és kisgyermeknevelő szakos diákok érkeznek a leghátrányosabb helyzetből. Második hipotézisünk a regionális és országos adatokhoz viszonyított eltéréseket prognosztizálta, s feltételezéseink ebben az esetben is megvalósultak - gondoljunk akár a települési lejtőre, akár a könyvek számára, akár pedig a szülők iskolai végzettségére. Elemzésünk módszertani korlátjának az tekinthető, hogy a hallgatók létszáma alacsony, így messzemenő következményeket nem vonhatunk le. Ezt a jövőben más évfolyamok bevonásával korrigálhatjuk, illetve az elkövetkező években a hallgatói létszámok emelkedése is várható.

Fontos eredményként tekinthetünk ugyanakkor a kar hallgatóinak arra az attitüdjére, amely a SNI-s, hátrányos helyzetü vagy roma gyermekek felé mutat. Ez egyfajta erőforrásként is kezelhető.

Munkánk legfontosabb eredményének talán az tekinthető, hogy egy lokális elemzés segítségével felvázolt egy olyan felsőoktatási környezetet, amely sajátosnak tekinthető a diákok szociokulturális háttere miatt. A képzések az intergenerációs mobilitásnak kínálnak terepet - láthatjuk, hogy a diákok nem „klasszikus” értelmiségi családokból érkeznek. Az intézménynek ugyanakkor ebben az intergenerációs mobilitással kapcsolatba hozható folyamatban kulcsfontosságú szerepe van, hiszen olyan készségeket és beállítottságokat kell átadnia és erősítenie, amelyek egy magasabb presztízsü intézményben sokkal inkább rendelkezésre állnak. Ennek a ténynek fontos tanulás- és tanításmódszertani konzekvenciái lehetnek, s nyilvánvaló, hogy az oktatók munkájában is más súlypontokat és kihívásokat generálnak. Ha a felsőoktatás „hozzáadott érték” koncepciójából indulunk ki (Pusztai, Bocsi és Ceglédi, 2016), akkor annyit mondhatunk, hogy egy ilyen profilú intézményben másfajta készségek fejlesztésére van szükség, mint egy magasabb presztízsü képzésben - lehetőleg minél komplexebb módon, s nem csupán az osztálytermek falai között. Ráadásul ennek a munkának a során az oktatók a családi erőforrásokra is kevésbé építhetnek. Véleményünk szerint ennek a pedagógiai munkának az eredménye, ha a hagyományos eredményességi mutatókkal kevésbé is mérhető (pl. OTDK szereplésekkel és helyezésekkel), össztársadalmi hozadéka miatt ugyanolyan fontos, mint a magasabb presztízsü intézményekben végzett, hallgatók tudományos eredményeire sokkal inkább fókuszáló oktatói munka. Mindez megindokolhatja azokat a törekvéseket, amelyek a hagyományos eredményességi koncepciók átalakítása mellett érvelnek, s olyan mérőeszközök használatát szorgalmazzák, amelyek a hosszútávú társadalmi hasznosságot is alapul veszik (Pusztai 2014).

\section{IRODALOM}

Archer, M. (1988). Az oktatási rendszerek expanziója. Budapest: Oktatáskutató Intézet.

Bocsi, V. (2016). Expanzió és szelektivitás - oktatási helyzetkép az ezredforduló után. In Nagy, Á. \& Székely, L. (Szerk.), Negyedszázad - Magyar Ifjúság 2012. (pp. 147-178) Budapest: ISZT Alapítvány; Iuvenis Ifjúságszakmai Mühely; Excenter Kutatóközpont; UISZ Alapítvány.

Bocsi, V. \& Rákó, E. (2015). A sajátos nevelési igényü gyermekek integrált nevelése mint a tanári pálya egy lehetséges kimenete. In Szilágyi, B, Mező, K \& Mező, F. (Szerk.), Az együttnevelés útjai. (pp. 2015-216) Debrecen: Debreceni Egyetemi Kiadó.

Ceglédi, T., Cziráki, Sz., Harsányi, Sz. G. \& Tóbi, István (2015). A tehetségek útja kutatás eredményeinek bemutatása. In Kónyáné Tóth M. \& Molnár Cs. (Szerk.), A fejlesztések eredményei és a jövő stratégiái az oktatásban. (262-272) Debrecen: Suliszerviz Oktatás és Szakértői Iroda, Suliszerviz Pedagógiai Intézet.

Engler, Á. (2014). Hallgatói metszetek. Debrecen: CHERD. 
Fónai M. (2009). A Debreceni Egyetem Tehetséggondozó Programjába került hallgatók rekrutációja és a szakok értékelése. In Karlovitz J. T. (Szerk.), Speciális kérdések és nézőpontok a felsőoktatásban. (pp. 49-66) Budapest: Neveléstudományi Egyesület.

Gazsó F. (2008). Közoktatás a zárványtársadalomban. In: Bódi. F. (Szerk), A helyi szociális ellátórendszer: tanulmánygyüjtemény. (pp. 129-144) Budapest: MTA Politikai Tudományok Intézete.

Hegedűs R. (2016): Számok-arányok-mintázatok a felsőoktatásba felvett hátrányos helyzetüek esetében. Modern Geográfia. 16. évf. 3. sz.

Hrubos, I. (2014). Expanzió - határok nélkül. Educatio, 23, (2), 205-215.

Hrubos, I. (1999). A felsőoktatás dilemmái a tömegessé válás idöszakában. Budapest: Oktatáskutató Intézet.

Kozma T. (2004). Kié az egyetem? Budapest: Új Mandátum Kiadó.

Ladányi J. (1994): Rétegződés és szelekció a felsőoktatásban. Budapest: Educatio.

Nagy P. T. (2012). A diplomás értelmiség népi rekrutációjának alakulása 1945 előtt és után. In Karády V. \& Nagy P. T. (Szerk.), Iskolázás, értelmiség és tudomány a 19-20. századi Magyarországon (pp. 122-136). Budapest: WJLF.

Polónyi, I. (2014). Régi, új felsőoktatási expanzió. Educatio, 23, (1), 1-21.

Pusztai, G. (2011). A láthatatlan kéztől a baráti kezekig. Budapest: Új Mandátum Kiadó.

Pusztai G. (2014): „Nem biztos, csak a kétes a szememnek...": Hallgatói eredményességi koncepciók és mutatók a felsőoktatás-kutatásban. In Nagy P. T. \& Veroszta Zs (Szerk.), $A$ felsőoktatás kutatása: Tisztelgö kötet Hrubos Ildikó születésnapjára (pp.146-165). Budapest: Gondolat.

Pusztai, G, Bocsi, V. \& Ceglédi, T. (2016). A felsőoktatás hozzáadott értéke közép-európai kontextusban. In Pusztai G., Bocsi V. \& Ceglédi T. (Szerk.), A felsőoktatás (hozzáadott) értéke: Közelítések az intézményi hozzájárulás empirikus megragadásához. (pp. 7-12.) Nagyvárad - Budapest: Partium PPS - Új Mandátum.

Pusztai, G., Bocsi, V. \& Kovács, K. (szerk.) (2015): Pedagógusképzésben résztvevő hallgatók követéses vizsgálata. Gyorsjelentés. Web: http://tanarkepzes.unideb.hu/ szaktarnet/kiadvanyok/pedagoguskepzesben_resztvevo_hallgatok_koveteses_vizsgalata_2. pdf. (Letöltés: 2017.07.26.)

Veroszta, Zs. (2016). Frissdiplomások 2015. Zárótanulmány. Web:https://www.felvi.hu/pub_bin/dload/DPR_tanulmanyok/frissdiplomasok_zarotanulma ny_2015.pdf (Letöltés: 2017.07.26.)

\section{INTERNETES HIVATKOZÁSOK}

Net1:https://www.ksh.hu/docs/hun/xstadat/xstadat_eves/i_zoi006.html Letöltés: 2017.07.26. Net2:https://www.ksh.hu/docs/hun/xstadat/xstadat_eves/i_zoi007a.html Letöltés: 2017.07.26. Net3:A felsőoktatás szociális dimenziója. $\overline{\mathrm{http}}$ ://tka.hu/docs/palyazatok/a-felsooktatasszocialis-dimenzioja.pdf letöltés: 2017.07.26. 


\title{
A MUNKAERÖ-PIACI INTEGRÁCIÓ HATÁSAI, KÜLÖNÖS TEKINTETTEL A MAGATARTÁS ÉS ÉLETMINŐSÉG VÁLTOZÁSAIRA
}

\section{Szerzők:}

Meisznerné Kuklek Noémi

Pécsi Tudományegyetem

Pusztafalvi Henriette

Pécsi Tudományegyetem

Egészségtudományi Kar

Egészségfejlesztési és Népegészségtani

Tanszék

Első szerző e-mail címe:

e-mail:noemi.kuklek@hotmail.com

\section{Lektorok:}

\author{
Barcsi Tamás \\ Pécsi Tudományegyetem \\ Egészségtudományi Kar \\ Egészségfejlesztési és Népegészségtani \\ Tanszék \\ Ágoston István \\ Pécsi Tudományegyetem \\ Egészségbiztosítási Intézet \\ Mező Ferenc \\ Eszterházy Károly Egyetem
}

Nemes Magdolna

Debreceni Egyetem

Meisznerné Kuklek Noémi, Pusztafalvi Henriette (2017): A munkaerő-piaci integráció hatásai, különös tekintettel a magatartás és életminőség változásaira. Különleges Bánásmód, III. évf. 2017/4. szám, 33-49. DOI 10.18458/KB.2017.4.33

\begin{abstract}
Absztrakt
A bemutatni kívánt program újszerüsége abban rejlik, hogy a mentális, szociális, vagy egészségügyi problémákkal küzdő álláskeresők számára nem csak a foglalkoztatás útján nyújt segítséget, hanem egy komplex, szolgáltatáscsomagot (munkaerő-piaci, szociális, egészségügyi szolgáltatás) is tartalmazó programmal, amely egyénre szabottan tud reagálni a fennálló nehézségekre, ezáltal javítva a résztvevő személyek életminőségét. Jelen tanulmány célja a foglalkoztatásba mentális, szociális vagy egészségügyi okból be nem vonható álláskeresők körében a speciális foglalkoztatási program bevonásának kezdetétől vizsgálni a magatartásbeli változásokat, valamint az életminőség javulását meghatározó tényezőket. Módszer: Vizsgálatunkban az általános jóllétet, megélhetéssel, anyagi háttérrel, családi háttérrel, egészségügyi, mentális problémákkal, munkavégzéshez kötődő problémákkal, szociális szolgáltatások igénybevételeivel, egészségügyi szolgáltatások igénybevételével kapcsolatos változásait monitoroztuk a program öt hónapja során, majd a kapott eredményeket kvantitatív és kvalitatív módszerekkel elemeztük. Következtetések: A jóllétnek mind a munkavállalók szubjektív érzelmi átéléseire, mind munkahelyi teljesítményükre,
\end{abstract}


munkahelyi magatartásukra pozitív hatása van, ezért a társadalomnak érdemes kiemelt figyelmet fordítania a munkáltatók érzékenyítésére, a komplex támogatási csomagot biztosító programok kialakítására, a munkavállalók életminőségének javulását meghatározó munkahelyi tényezők biztosítására. Az életminőség vizsgálatára irányultan eredményeink megerősítették, hogy megfelelő támogatással (pl. mentorálással, tanácsadással, támogató programok révén), növelhető a munkával, a munkahellyel való elégedettség, mely nemcsak az egyén, de a munkaadók, és a társadalom szempontjából is számtalan előnnyel jár: javul a munka minősége, a munkahelyi viselkedés és morál, kevesebb lesz a hiányzás, kisebb a betegségi és a fluktuációs ráta, nő a foglalkoztatottsági ráta.

Kulcsszavak: életminőség, munkaerő piaci szolgáltatások, szociális szolgáltatások, hátrányos helyzet

\title{
Diszciplína: egészségtudomány
}

\begin{abstract}
Effects of labor market integration, in particular changes in behavior and quality of life

The program you want to show is novel because it provides assistance to job seekers who face mental, social or health problems, it also provides a complex service package that includes labor market, social and health services. The program can respond individually to the existing difficulties, thus improving the quality of life of the participants. The aim of the study is to examine the factors that determine the behavioral changes and the quality of life quality among the jobseekers who can't be included in employment for mental, social or health reasons. Methods: In our study we monitored changes in general well-being, livelihoods, financial backgrounds, family backgrounds, health problems, work-related problems, social services, and healthcare services during the five months of the program, and analyzed the results obtained by quantitative and qualitative methods. Conclusion: Well-being has a positive effect on both the subjective emotional experiences of employees, their work performance and their workplace behavior. We think that society should pay attention to sensitizing employers, develop insurance programs for complex package of support, to ensure workplace factors influencing the improvement of the quality of life for workers' attention. The quality of life of our study confirmed that adequate support (mentoring, counseling, through programs supporting), to increase job satisfaction, workplace, which has many advantages in terms of not only the individual, but employers and society: improving the quality of work, the Workplace behavior and morale, less absenteeism, lower sickness and fluctuation rates, and employment rate increases.
\end{abstract}

Keywords: Quality of life, labor market services, social services, disadvantaged

Disciplines: health sciences

\section{BEVEZETŐ}

A 2016. július 1-én indult pilot speciális közfoglalkoztatási program célja, a foglalkoztatásba mentális, szociális vagy egészségügyi okból be nem vonható álláskeresők személyi körének feltárása, valamint a számukra nyújtható, személyre szabott szociális, egészségügyi és munkaerő piaci szolgáltatások, felzárkózást elősegítő képzések meghatározása az érintett személyek foglalkoztatásának, foglalkoztathatóságának növelése céljából. 


\section{Elözmények}

A Kormány általános célja a lehetőség szerinti, minél szélesebb körü, teljes foglalkoztatás megvalósítása. Ennek érdekében a jelenleg a közfoglalkoztatásba is nehezen bevonható személyek foglalkoztatását és foglalkoztathatóságát kívánja fejleszteni, hogy számukra a foglalkoztatás mellett munkaerö-piaci, szociális és egészségügyi szolgáltatásokat nyújt. A közfoglalkoztatás 2016.évi céljairól és a közfoglalkoztatás szempontjából kiemelt települések meghatározásáról szóló 1040/2016. (II.11.) Kormány határozat 2.d) ${ }^{\mathrm{i}}$ pontja a Belügyminisztérium, a Nemzetgazdasági Minisztérium, valamint a Nemzeti Fejlesztési Minisztérium számára határozott meg feladatot, mely szerint a tárcák feladata, hogy vizsgálják meg a foglalkoztatásba mentális, szociális vagy egészségügyi okból be nem vonható álláskeresők személyi körét, valamint a számukra nyújtható, személyre szabott szociális, egészségügyi és munkaerő piaci szolgáltatások, felzárkózást elősegítő képzések nyújtásának lehetőségét az érintett személyek foglalkoztatásának, foglalkoztathatóságának növelése céljából. A program megvalósítását két lépcsőben tervezték, melynek első fázisában a program hasznosságát, eredményességét tesztelik. Országos kiterjesztésre csak ennek tükrében, a tapasztalapok összegzését követően kerülhet sor. A program második lépcsőjét a befejezést követő időszak jelenti, melynek során a Belügyminisztérium, a Nemzetgazdasági Minisztérium és az Emberi Erőforrások Minisztériuma közös vizsgálatát követően, melyben vizsgálják a program tapasztalatait, eredményeit, értékelik azokat, majd ez alapján javaslatot tesznek a program folytatására vonatkozóan. A megvalósítási helyszínek, az úgynevezett közfoglalkoztatási pontok önkormányzatoknál történő létrehozásával a településen és a környezö településeken lévő hátrányos helyzetü személyek foglalkoztatása biztosíthatóvá válik. Ennek számos pozitív hatása van, úgymint nő az adott településen a foglalkoztatottak létszáma, helyben munkalehetőséget teremt, javítja a nehezen elhelyezhető személyek mentális, szociális helyzetét. http://www.kormány.hu ${ }^{i i}$ A beazonosított problémák alapján a munkavégzésre képes személyek a közfoglalkoztatási ponton végezhetnek az állapotuknak megfelelő egyszerü, rövid időn belül elsajátítható, betanított munkafeladatokat. (pl.: egyszerü összeszerelési tevékenység, csomagolás, textilipari, bőripari tevékenységek, dobozhajtogatás stb.).

\section{A program kezdete}

2016. június 7-én jelent meg a Nemzetgazdasági Minisztérium pályázati felhívása a foglalkoztatás elősegítéséről és munkanélküliek ellátásáról szóló 1991. évi IV. törvény 40.§iii_ a alapján, mely központi munkaerő-piaci program keretében speciális közfoglalkoztatási programhoz kapcsolódó munkaerö-piaci szolgáltatás támogatás nyújtására biztosít lehetőséget. A sajtóban még indulása előtt számos támadás célpontjává vált a pályázat, illetve a megvalósítandó program, ám mindezek ellenére a pályázat eredményekét 2016.július 1-én négy megyében indult el a megvalósítás: Baranya, Borsod-Abaúj-Zemplén, SzabolcsSzatmár-Bereg és Zala megyékben, mintegy háromszáz fővel. A kísérleti programban résztvevő települések kiválasztására a Belügy Minisztérium, az érintett járási és kormányhivatalok, valamint a települési önkormányzatok közös szakmai egyeztetése után került sor. A program az aktuálisan müködő önkormányzati nonprofit gazdasági társaságoknál, vagy települési önkormányzatoknál került megvalósításra. A program célja a mentális, szociális vagy egészségügyi okból foglalkoztatásba be nem vonható álláskeresők foglalkoztathatóságának növelése. A közvetlen célcsoportot a pályázati felhívás szerint a regisztrált álláskeresők alkották, akiknek legalább 40\%-os munkaképesség csökkenése van, minimum 24 hónapja, azaz tartósan álláskeresők, nyolc általános iskolai végzettséggel nem rendelkező, minimum három kiskorú gyermeket nevel vagy a családban legalább két fó regisztrált álláskereső van. Mivel a Zala megyében megvalósított programban vettem részt, a 
továbbiakban a Megyében megvalósításra került Pilot program tapasztalatait szeretném a továbbiakban összefoglalni.

\section{A kiválasztás folyamata}

A kiválasztott négy megye közül az egyik Zala Megye és ezen belül Nagykanizsa település kapta a lehetőséget a program megvalósítására. A Zala Megyei Kormányhivatal Nagykanizsai Járási Hivatal Foglalkoztatási Osztályának korábbi időszakból vezetett nyilvántartásából kerültek kiválasztásra a bevonandó személyek. A speciális közfoglalkoztatási programba meghatározott létszám két közfoglalkoztatási helyen 25, illetve 50 föt, azaz összesen 75 személyt jelentett. Azon ügyfelek kerültek megszólításra, akik tartósan (több mint 12 hónapja) az álláskeresői nyilvántartásba szerepeltek, nem volt közvetítési eseményük, vagy az rendszeresen sikertelen volt, foglalkoztatásuk folyamatosan meghiúsult, továbbá, a járási hivatal munkatársai által is ismert szociális, mentális, vagy egészségügyi problémával küzdenek. Az egészségügyi problémákat minden esetben hivatalos orvosi dokumentáció is alátámasztja.

A fent leírt szempontok alapján az első 2016.06.09.-2016.06.29. közötti időtartamban nyolc alkalommal történt behívás a helyi Foglalkoztatási Osztályra, melyet személyre szóló közvetítői beszélgetésre behívó levelet jutattak el az érintettek részére. A beszélgetésröl, csoportos tájékoztatókról feljegyzés, illetve jelenléti ív készült, melyben rögzítésre kerültek az ügyfél adatok, a tartós álláskeresés okai, a felkínált lehetőség vállalása illetve elutasítása. Az elutasítás esetén ezzel kapcsolatos indoklás.

A programba meghatározott létszám eléréséhez június, július és augusztus hónapokban is szükséges volt a behívások megszervezése. A három hónap során összesen 1025 fö került megszólításra, melyből 595 fö, azaz a megszólítottak 58\%-a jelent meg. A megjelentek közül a tájékoztatás során 327 fő nyilatkozta azt, hogy nem kíván részt venni a programban, míg 210 fó vállalta a foglalkoztatást. Összesen 103 fővel kötöttek a foglalkoztatók közfoglalkoztatási jogviszonyt azonban a foglalkoztatáshoz kapcsolódó orvosi alkalmassági vizsgálat során számos személyt egészségügyi szempontból alkalmatlannak találtak a speciális munkavégzésre is. A pályázatban elöírt 25 és 50 fös, a programba bevont és foglalkoztatásra került létszámot 2016 szeptemberében sikerült, mindkét foglalkoztatási helyszínen elérni. A fenti adatok tükrében megállapítható, hogy a speciális közfoglalkoztatás célcsoportját képező személyek esetében jelentős a visszautasítás, azaz a foglalkoztatástól való elzárkózás aránya. Azon személyek esetében, akik a megkeresés ellenére sem jelentek meg a tájékoztatón, illetve foglalkoztatás céljából a számukra kijelölt foglalkoztatási helyszínen (számuk 764 fö) szankciós intézkedések megtételére nem került sor, a továbbiakban is folyósították számukra a foglalkozást helyettesítő támogatást, illetve egyéb ellátásokat.

\section{A pilot programhoz kapcsolódó szolgáltatások}

A pilot program újszerüsége abban rejlik, hogy a mentális, szociális, vagy egészségügyi problémákkal küzdő álláskeresők számára nem csak a foglalkoztatás útján kíván segítséget nyújtani, hanem egy komplex, szolgáltatáscsomagot (munkaerő-piaci, szociális, egészségügyi szolgáltatás) is tartalmazó programmal, amely egyénre szabottan tud reagálni a fennálló nehézségekre.

Munkaerö-piaci szolgáltatások

A program megkezdésekor a munkaerő piaci szolgáltatások közül azon programelemek kerültek alkalmazásra, amelyek a munkára való felkészítést, a motivációt, a 
kulcskompetenciák fejlesztését célozták meg. A következő időszakban a foglalkoztatásra került a hangsúly, míg a program vége elött két-három hónappal az elhelyezkedést segítő munkaerő piaci szolgáltatások kerültek alkalmazásra. A program teljes időtartama alatt mentori szolgáltatás egészítette $\mathrm{ki}$ az egyénre szabott, egyéni igényekhez igazodó egészségügyi és szociális szolgáltatásokat.

\section{Mentori szolgáltatás}

A mentori szolgáltatás folyamatos, a programba vonástól a programból való kikerülést követő harminc napig tartott, mely magában foglalta a nyomon követést és utógondozást.

\section{Szociális szolgáltatások}

A szociális szolgáltatások közül a célcsoport számára az alábbiak értelmezhetők: A családsegítés a szociális vagy mentálhigiénés problémák, illetve egyéb krízishelyzet miatt segítségre szoruló személyek, családok számára az ilyen helyzethez vezető okok megelőzése, a krízishelyzet megszűntetése, valamint az életvezetési képesség megőrzése céljából nyújtott szolgáltatás. A munkaerő piaci, szociális és egészségügyi szolgáltatások háromoldalú megállapodásban kerültek rögzítésre. A három szerződő fél a szolgáltatást nyújtó, a közfoglalkoztató, valamint a megyei kormányhivatal.

Egészségügyi szolgáltatások

Szükség esetén az alábbi ellátások igénybevételét kell segíteni: Közösségi alapellátások: A közösségi ellátás a pszichiátriai, illetve a szenvedélybetegek részére nyújtott közösségi alapellátás, valamint a szenvedélybetegek részére nyújtott alacsonyküszöbü ellátást jelenti. Pszichiátriai-, szenvedélybetegek nappali ellátása. Egészségügyi szolgáltatások: Ha a programba bevonásra került személy egészségügyi vizsgálata, ellátása szükséges, a közfoglalkoztatott mentora a lakóhelye szerinti területi ellátási kötelezettséggel rendelkező egészségügyi szolgáltatóhoz (járóbeteg szakellátó, háziorvos) kell, hogy irányítsa, szükség esetén kísérje az ügyfelet. Vannak beutaló nélkül és beutalóval igénybe vehető ellátások.(Kötelező egészségbiztosítás ellátásairól szóló 1997. évi LXXXIII. törvény ${ }^{i v}$ végrehajtásáról szóló 217/1997. (XII.1.) Kormány rendelet `tartalmazza. Mentális probléma esetén pszichiátria vagy klinikai szakpszichológiai járóbeteg szakrendelésre, szenvedélybetegség probléma esetén az addiktológiai járóbeteg szakrendelésre, egyéb egészségügyi probléma esetén a választott háziorvoshoz vagy a területileg illetékes háziorvoshoz történő irányítás javasolt, ő tudja beutalni a megfelelő szakrendelésre, diagnosztikai vizsgálatra az ügyfelet. Amennyiben a járóbeteg szakrendelésen az ügyfél végleges ellátása nem oldható meg és állapota indokolja, a járóbeteg szakrendelés szakorvosa beutalja a területi ellátási kötelezettséggel rendelkező fekvőbeteg (aktív, rehabilitáció) szakellátást végző egészségügyi szolgáltatóhoz. A munkaerő piaci, szociális és egészségügyi szolgáltatások háromoldalú megállapodásban kerültek rögzítésre. A három szerződő fél a szolgáltatást nyújtó, a közfoglalkoztató, valamint a megyei kormányhivatal.

\section{A pályázatban kiírt szolgáltatások keretei}

A bevonási szakasz 2016.07.01.-2016.07.31-ig tartott. Ebben a szakaszban a Járási Hivatal foglalkoztatási osztálya az informatikai rendszerben lévő profiling besorolás szerinti harmadik kategóriába tartozó álláskeresőket szólítja meg, akik valamilyen okból az elmúlt egy évben nem vettek részt közfoglalkoztatásban, vagy egyéb munkaviszony/közfoglalkoztatási jogviszony létesítését elősegítő munkaerő-piaci tevékenységben. A megszólított álláskeresők csoportos tájékoztató formájában kaptak információt a speciális programban kapható segítségről és annak feltételeiről. A kiválasztott 
álláskeresőket a foglalkoztatási osztály munkatársa közvetítette a programba. A programba közvetítést követően foglalkozás-egészségügyi vizsgálatra szóló beutalót kapott az ügyfél. A foglalkozás-egészségügyi vizsgálat elvégzését követően annak eredményétől függően,- ha az egyén alkalmas minősítést kapott-bekerült a speciális programba (közvetítése sikeres). A foglalkoztatási szerv jelölte ki a megfelelö speciális közfoglalkoztatási pontot, ahol a foglalkoztatóval közfoglalkoztatási jogviszonyt létesített. Ebben az időszakban került kitöltésre az előzetes bevonás adatlapja, (Elözetes diagnózis pontozóskála) ahol egy részletes interjú keretében meghatározásra kerültek az álláskereső elhelyezkedését akadályozó problémák és ezek fő megoldási irányai. Figyelembe véve az álláskereső beszámolója alapján a szociális és egészségügyi területek szegmentálására vonatkozó észrevételeket. E szerint három fó terület a szociális, egészségügyi, és a munkaerő piaci problémák kerülhettek beazonosításra.

Személyeként a program ideje alatt legalább 5 egyéni tanácsadás és 2 csoportos foglalkozás biztosítását írta elő a program, az alábbi bontásban:

I. Bevonási szakaszban (2016. július 01. - 2016. július 31.): Minimálisan, egyénenként három egyéni tanácsadás, mely munkavállalási- rehabilitációs, pszichológiai tanácsadás nyújtását tette lehetővé.

II. Megvalósitási szakaszban (2016. augusztus 01. - október 31.): Minimálisan elöírt 2 csoportos foglalkozás, egyéni munkavállalási tanácsadás, pszichológiai tanácsadás, munkavállalói kulcsképességet, kulcskompetenciákat fejlesztő csoportos foglalkozás (4 napos), motivációs csoportos foglalkozás (5 napos), személyiségfejlesztést, beilleszkedést és önálló életvitelt segítő csoportos foglalkozás megtartását írta elő.

III. Befejezö szakaszban (2016. november 01. - november 30.): 2 egyéni tanácsadás, tanulási képességek és készségek vizsgálata, egyéni munkavállalási tanácsadás, egyéni álláskeresési tanácsadás, álláskeresési technikák (3 napos)

- valamint, a program ideje alatt a folyamatos mentori szolgáltatás biztosítását.

Utókövetés: 2016.12.01.-2016.12.31.-mentori utókövetés

A támogatott szolgáltatás időtartama: 2016. július 01. - 2016. november 30., azonban ezt harminc napos mentorálási folyamat egészíti ki az utókövetés érdekében 2016. december 31ig. A szolgáltató 2 fő teljes munkaidős munkavállalási tanácsadó, valamint 2 fő teljes munkaidős, mentori szolgáltatást biztosító személy munkaviszonyban vagy megbízási szerződéssel történő alkalmazásával 75 fő számára biztosította a szolgáltatását a program ideje alatt. A megvalósítás helyszínein 2-2 munkavezető végezte a munkafeladatok koordinálását. 1253/2016.(VI.6.) Kormány határozat ${ }^{\mathrm{vi}}$

\section{A pilot program speciális juttatásai}

A speciális közfoglalkoztatási program időtartama alatt a résztvevő közfoglalkoztatottak új típusú, speciális közfoglalkoztatási bérben részesültek, melynek összege alacsonyabb mértékü a jelenlegi közfoglalkoztatási bérnél. Tekintettel arra, hogy a célcsoport halmozott hátrányos helyzete miatt elsősorban nem gazdasági értelemben vett értékteremtő foglalkoztatás valósult meg, illetve nem elvárható tőlük olyan színvonalú és teljesítményü munkavégzés, ami a többi közfoglalkoztatottól, így bérezésüket ennek megfelelően, csökkentett, de a passzív segélyezéshez képest magasabb mértékü, napi hat órás munkavégzés mellett került kialakításra. A közfoglalkoztatási bér és a közfoglalkoztatási garantált bér megállapításáról 
szóló 170/2011.(VIII.24.) Kormány rendelet ${ }^{\mathrm{vii} a l a p j a ́ n ~ a ~ s p e c i a ́ l i s ~ k o ̈ z f o g l a l k o z t a t a ́ s i ~ b e ́ r ~ h a v i ~}$ 41.556 Ft-ban került megállapításra, a legalább középfokú iskolai végzettséget és szakképesítést igénylő munkakör betöltése esetén a közfoglalkoztatási pontok által indított speciális közfoglalkoztatási programban hat órában foglalkoztatottat megillető speciális garantált közfoglalkoztatási bér 53.277 Ft-ban került megállapításra. A munkabér mellett a programban résztvevők számára, napi egyszeri meleg étkezést, munkaruhát biztosítottak a foglalkoztatók a megvalósítás helyszínein.

\section{A tevékenységek}

Nagykanizsán, mint azt már írtam két helyszínen került megvalósításra a program 25 , illetve 50 fös keretszámmal. Mindkét helyszínen a munkafolyamatok egyszerü, rövid időn belül elsajátítható munkafeladatokat jelentettek, hiszen a mintaprogram „elsősorban értékteremtő, hasznos, a helyi sajátosságokon alapuló, a település önfenntartását elősegítő tevékenységet" támogatta.(375/2010.(XII.31.) Korm. rendelet) ${ }^{\text {viii }}$ A kormányrendelet iránymutatásainak megfelelően asztalosipari tevékenységet, lakatosipari tevékenységet, festést, felületkezelési tevékenységet, drótfonatkészítést, kerékpár utak, Kanizsa Bike dokkoló állomás takarítását, tisztántartását, közterületek tisztántartását és üvegházi munkát végeztek a programba kerülők.

A programban résztvevők statisztikai adatait elemezve a kor szerinti megoszlást tekintve a 25 év alattiak száma 0 fö. Ezzel szemben az 50 év felettiek száma 36 fö, ez a korcsoport meghatározó a jelen foglalkoztatásban, mivel az összlétszám 53 \%-át teszi ki létszámuk. A 40 és 49 év közöttiek száma 21, amely az összlétszám 30\%-át jelenti, számukra nagyon fontos a munkalehetőség megtalálása. A programból kilépők kor szerinti vizsgálatát tekintve nem találunk kiugróan magas adatot, itt a legmagasabb értéket az 55 év felettiek alkotják (1.táblázat).

1. táblázat. A szolgáltatás célcsoportja. (Forrás:a Szerzö)

\begin{tabular}{|l|r|r|r|}
\hline \multicolumn{1}{|c|}{ Kor } & Létszám(fö) & \multicolumn{1}{c|}{ Programból kilépők száma (fö) } \\
\hline 25 év alatt & 0 & 3 \\
\hline $25-29$ év & 1 & 1 \\
\hline $30-34$ év & 6 & 2 \\
\hline $35-39$ év & 4 & 6 \\
\hline $40-44$ év & 7 & 5 \\
\hline $45-49$ év & 14 & 5 \\
\hline $50-54$ év & 12 & 7 \\
\hline 55 év felett & 24 & 8 \\
\hline Összesen & 68 & 37 \\
\hline
\end{tabular}

Az iskolai végzettség tekintetében jelentős azok száma, akik az általános iskolát sem fejezték be, számuk 13 fö, a teljes létszám 19 \%-át jelenti, amely jelentősen hátráltatja a későbbi foglalkoztatásukat is. Esetükben lehetőség a normál nyolc órás foglalkoztatásba történő átvétel, illetve a nyolc osztály befejezését segítő felzárkóztató tanfolyami képzés jelentheti a továbblépés lehetőségét (2.táblázat). 
2.táblázat: Iskolai végzettség szerinti besorolás (forrás: a Szerzö)

\begin{tabular}{|l|r|r|}
\hline \multicolumn{1}{|c|}{ Végzettség típusa } & Létszám (fö) & Programból kilépők létszáma (fö) \\
\hline Általános iskolai végzettség nélkül & 13 & 9 \\
\hline Általános iskolai végzettség & 33 & 11 \\
\hline Szakiskola & 4 & 4 \\
\hline Szakmunkásképző & 16 & 8 \\
\hline Szakközépiskola & 2 & 4 \\
\hline Technikum & 0 & 1 \\
\hline Gimnázium & 0 & 0 \\
\hline Főiskola & 0 & 0 \\
\hline Egyetem & 0 & 0 \\
\hline Összesen & 68 & 37 \\
\hline
\end{tabular}

Tapasztalataink szerint egy, illetve két osztály megszerzését viszonylag könnyen vállalják az érintett személyek, azonban ennél több osztály hiányzása esetén elzárkóznak a képzés lehetősége elött. A bevonásra kerültek többségét, a program $49 \%$-át, 33 fö az általános iskolát végzettek alkotják. Szakmával 16 fö rendelkezik, a bevontak $23 \%$-át jelenti. Azonban fontos esetükben megjegyezni, hogy sok esetben a megszerzett képesítés munkaerő piaci szempontból elavult, vagy az egészségi állapotuk nem teszi lehetővé számukra a szakmájukban való munkavégzést. A programból kilépők esetében szintén a legmagasabb 11 fö azoknak a száma, akik általános iskolai végzettséggel rendelkeznek, és esetükben is elmondható, hogy szintén magas az általános iskolát be nem fejezettek létszáma is, 9 fö. ( 2 . táblázat)

A programba kerüléskor felmérésre került a regisztrált álláskeresők száma is, ez 60 föt jelentett, minimum 24 hónapja, azaz tartós álláskeresőnek 24 személy vallotta magát, míg arra a kérdésre, hogy a családban legalább 2 fő regisztrált álláskereső van, 21 személy adott pozitív választ. A programból kilépők tekintetében elmondható, hogy ahol a családban legalább két fő a regisztrált álláskereső egy családban, csak egy fö jogosult a foglalkoztatást helyettesítő támogatás igénylésére, így ezen személyek esetében elsődleges szempont a minél magasabb jövedelem szerzés biztosítása. 1990. évi LXV. törvény 7. ${ }^{\text {ix }}$,1997. évi LXXXIII. törvény 83 . $\S^{\mathrm{x}}$ (3. táblázat).

3.táblázat: Munkaerö piaci státusz a programba kerülés elött (forrás: a Szerzö)

\begin{tabular}{|l|r|r|}
\hline \multicolumn{1}{|c|}{ Státusz } & $\begin{array}{c}\text { Létszám } \\
\text { (fö) }\end{array}$ & \multicolumn{2}{c|}{$\begin{array}{c}\text { Programból kilépők } \\
\text { létszáma (fó) }\end{array}$} \\
\hline Regisztrált álláskereső & 38 & 42 \\
\hline Minimum 24 hónapja tartós álláskereső & 20 & 11 \\
\hline A családban legalább 2 fö regisztrált álláskereső van & 10 & 37 \\
\hline Összesen & 68 & \\
\hline
\end{tabular}

A programba kerüléskor felmérésre került a regisztrált álláskeresők száma is, ez 60 föt jelentett, minimum 24 hónapja, azaz tartós álláskeresőnek 24 személy vallotta magát, míg arra a kérdésre, hogy a családban legalább 2 fö regisztrált álláskereső van, 21 személy adott pozitív választ. A programból kilépők tekintetében elmondható, hogy ahol a családban 
legalább két fő a regisztrált álláskereső egy családban, csak egy fö jogosult a foglalkoztatást helyettesítő támogatás igénylésére, így ezen személyek esetében elsődleges szempont a minél magasabb jövedelem szerzés biztosítása. 1990. évi LXV. törvény 7. ${ }^{\mathrm{xi}}, 1997$. évi LXXXIII. törvény 83 . $\S^{x i i}$ (lásd: 3 . táblázat)

A nemek összetételét nézve jelentős a férfiak többsége, eléri a $43 \%$-ot. A 68 főből 39 férfi került bevonásra, ez a teljes létszám $57 \%$-át jelenti. A nemek összetételét az is jelentősen befolyásolja, hogy az egyik munkáltatónál többségében férfiak alkalmazását lehetővé tevő munkafeladatok kerültek kialakításra. A programból kilépettek esetében jóval magasabb a férfiak távozásának aránya. Ennek oka, hogy fizikai munkavégzést biztosító lehetőséget a térségben jóval könnyebben találnak a férfiak, mint a nők.(lásd: 4.táblázat)

4.táblázat. A programban résztvevö személyek nemek szerinti összetétele (forrás: a Szerzö)

\begin{tabular}{|l|l|l|}
\hline Nemek & Összesen (fó) & Programból kilépők száma (fö) \\
\hline Nő & 29 & 10 \\
\hline Férfi & 39 & 27 \\
\hline Összesen & 68 & 37 \\
\hline
\end{tabular}

\section{Módszerek és eszközök}

\section{A mintaválasztás sajátosságai, a minta jellemzői}

A vizsgálatot a Zala megyében megvalósuló Pilot kísérleti programba bevonásra kerülő személyek körében végeztük. A minta összetétele így adott volt, összesen 105 fö került a mintába. A bevonásra került személyek esetében a válaszadás önkéntes volt, a papír-ceruza alapú kérdőívek havonta a mentori szakmai beszámoló részeként, minden személyre vonatkozóan kitöltésre kerültek. Ezeket az adatlapokat alapul véve vizsgáltuk a programba bevonásra került személyek esetében az egyes hónapokra vonatkozóan felmerült problémákat, az életminőség, megélhetéssel, anyagi háttérrel, családi háttérrel, egészségügyi, mentális problémákkal, munkavégzéshez kötődő problémákkal, szociális szolgáltatások igénybevételeivel, egészségügyi szolgáltatások igénybevételével kapcsolatos változásait. Az adatlap itemeire egy ötfokú Likert-skálán történt a válaszadás (jelentösen javult $=5$, részben javult $=4$, nem változott $=3$, romlott $=2$, jelentősen romlott $=1$. Az adatlap kitöltése során a mentoroknak a munkavállalók életminőségének változását kellett kifejezni. Átszámoltuk a Likert skálán kapott eredményeket, ha nem történt változás a vizsgált változók tekintetében 0 , ha javulás történt, a javulás mértékétöl függően 1,2 értéket kapott, ha romlás következett be, a romlás mértékétől függően $-1,-2$ értéket kapott. A kapott eredményeket összesítettük, majd ezekből átlagot számolva kaptuk az eredményeket.

\section{Munkavégzéshez kötődö problémák}

A programba bevonásra került személyek esetében lekérdezést végeztünk arra vonatkozóan mikor volt az utolsó nyílt munkaerő piaci munkaviszony? 
5.táblázat. Utolsó nyilt munkaerö piaci munkaviszony (forrás: a Szerzö)

\begin{tabular}{|l|c|}
\hline \multicolumn{1}{|c|}{ Év } & Személyek száma (fö) \\
\hline nem volt munkaviszonya & 14 \\
\hline $1990-2000$ & 12 \\
\hline $2001-2010$ & 69 \\
\hline $2011-2015$ & 9 \\
\hline 2016 után & 1 \\
\hline Összesen & 105 \\
\hline
\end{tabular}

Az 5. táblázat mutatja be, hogy 14 fö egyáltalán nem rendelkezik nyílt munkaerő piaci tapasztalattal, 12 személy, utoljára 16 évvel ezelött dolgozott a versenyszférában, míg a legtöbb személy, számuk 69 több mint hat évvel ezelőtt dolgozott nyílt munkaerő piacon. Megélhetésüket segélyek, rövidebb-hosszabb közfoglalkoztatási-, alkalmi, illetve „fekete” munka biztosította.

\section{1. ábra. Igazolatlan távollétek száma (forrás: a Szerzö)}

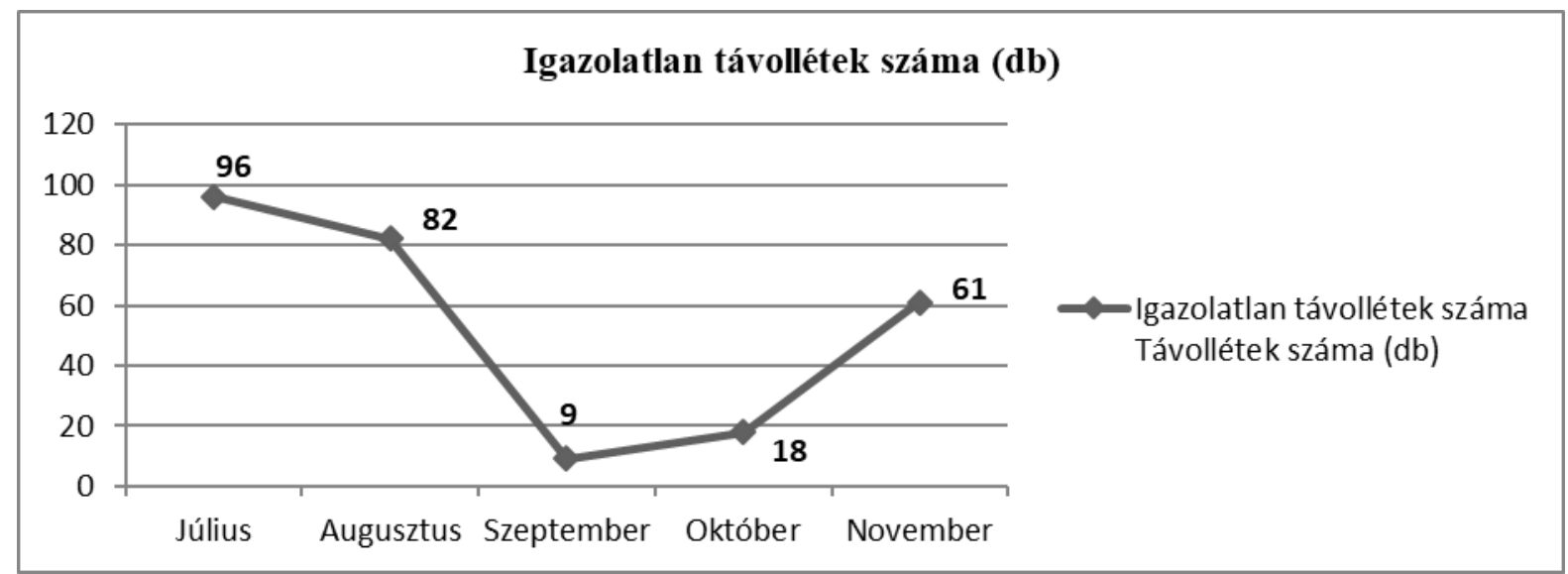

A program öt hónapja során monitoroztuk a munkavégzéshez kötődő magatartásbeli problémák változását valamint a munkavégző képesség változását az igénybevett egészségügyi szolgáltatások számán keresztül. Szeptemberben a magatartásbeli problémák tekintetében az igazolatlan távollétek számát alapul véve, látható, hogy július és hónapokban volt a legmagasabb az igazolatlan hiányzások száma, annak ellenére, hogy a munkáltatók törekedtek arra, hogy elsősorban a szabadságok kerüljenek kiadásra távollét esetén. (1.ábra) Meg kell azonban jegyezni, hogy a nyári hónapokban könnyü viszonylag jól fizető alkalmi munkát találni, ami jóval magasabb bevételi forrást jelent a pilot programban kapott jövedelemnél, illetve ha valaki a munkavállalók közül ittas állapotban jelent meg a munkanap kezdetén, vagy a nap folyamán ittas állapotba került (mivel az esetek többségében külterületeken végeztek az érintett személyek munkát, gyakran felügyelet nélkül, több esetben előfordult, hogy nap folyamán kerültek ittas állapotba), igazolatlannak tekintették az adott napot. Az igazolatlan hiányzások száma szeptember és október hónapokban jelentősen vissza esett, pozitív változást tapasztaltunk, majd a program utolsó harmadában ismét emelkedő tendenciát tapasztaltunk. Ennek hátterében egyrészt az áll, hogy erre az időszakra általában 
elfogytak a szabadságok, illetve erre az időszakra realizálódott egyes személyek tekintetében a továbbfoglalkoztatás lehetősége. Azon személyek esetében, akik számára a munkáltató nem jelezte a továbbfoglalkoztatási szándékot, a munkamorál jelentős mértékben negatív irányba változott. Meg kell azonban jegyezni egyes személyek esetében a magatartásbeli problémák, konfliktus munkavállaló-munkavállaló, munkavállaló-munkáltató között, a program egésze alatt jellemzőek voltak. A munkavégző képesség változását az egészségügyi szolgáltatások igénybevételén keresztül vizsgáltuk, kiugróan magas igénybevételt mutat minden hónapban a háziorvosi-alapellátás igénybevétele összesen 109 esetben, majd ezt követi a különböző szakrendelésekre irányítások száma, amely az öt hónap során összesen 58 alkalommal valósult meg. A pszichiátria szakrendelésen egy esetben, klinikai és mentálhigiénés szakrendelésen öt alkalommal történt megjelenés. Az aktív, valamint a krónikus ellátás igénybevételeinek száma ehhez viszonyítva az egy-egy esettel elenyészőnek mondható.

\section{Fluktuáció}

A munkavégzést jelentősen befolyásolja a fluktuáció, ezért kimutatást végeztünk a programba bevonásra került személyek esetében a fluktuáció mértékéről és annak okáról.(2.ábra, 6. táblázat).

6.táblázat: Fluktuáció (forrás: a Szerző)

\begin{tabular}{|l|r|r|r|r|r|}
\hline \multicolumn{1}{|c|}{ kilépés okai } & július & augusztus & szeptember & október & november \\
\hline egészségügyi orvosi alkalmatlanság & 4 & 0 & 1 & 0 & 0 \\
\hline igazolatlan távollét & 9 & 3 & 0 & 1 & 1 \\
\hline $\begin{array}{l}\text { nyolc órás közfoglalkoztatásba } \\
\text { átvétel }\end{array}$ & 2 & 0 & & & \\
\hline költözés & 0 & 0 & 0 & 3 & 1 \\
\hline nyílt munkaerö-piac & 1 & 4 & 2 & 1 & 0 \\
\hline halál & 1 & 0 & 0 & 0 & 0 \\
\hline ápolási díj & 0 & 2 & 0 & 0 & 0 \\
\hline Összesen & 17 & 9 & 3 & 6 & 2 \\
\hline
\end{tabular}

2.ábra: Fluktuáció (forrás:Szerzö)

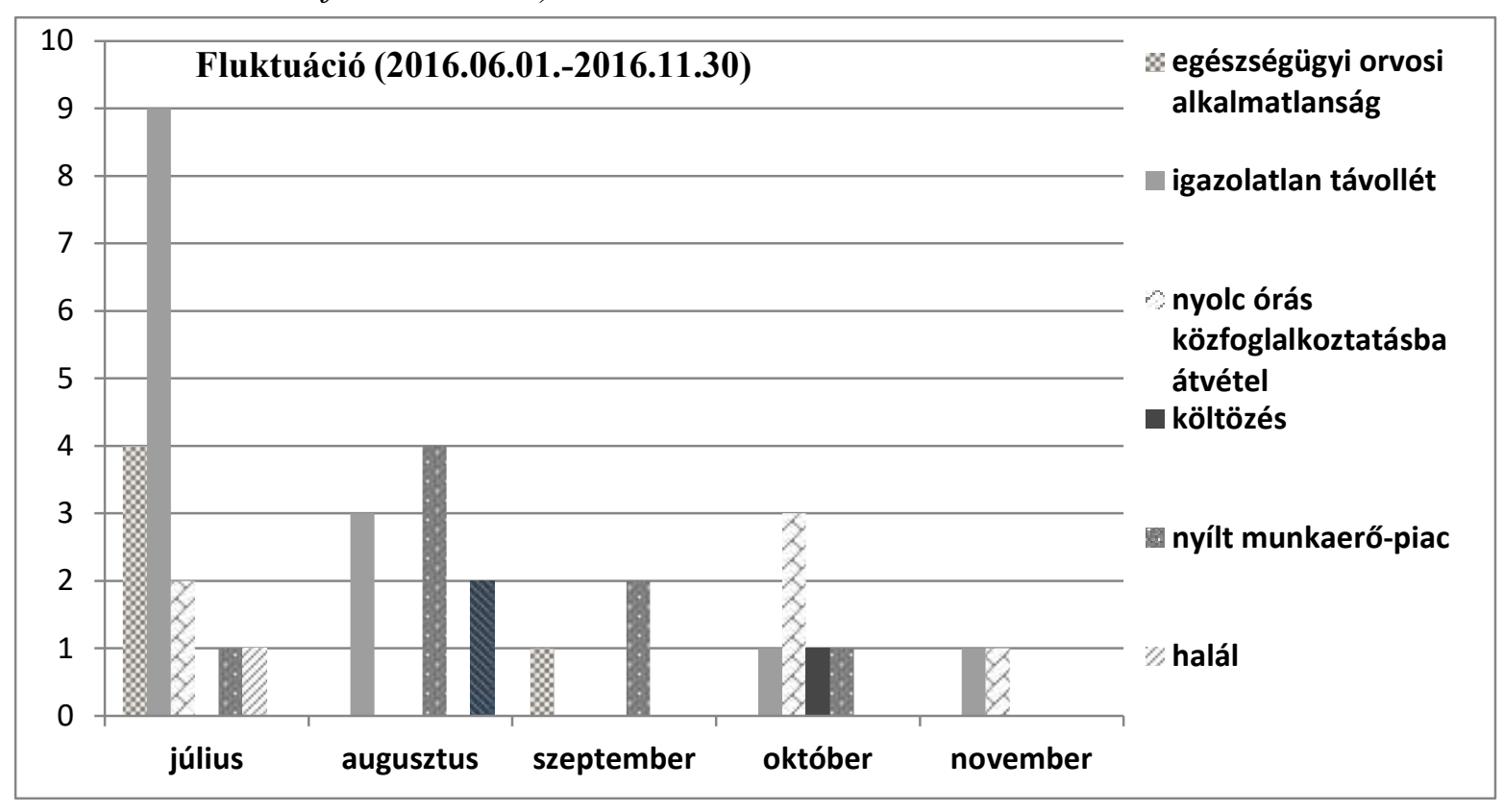


A munkavégzést jelentősen befolyásolja a fluktuáció, ezért kimutatást végeztünk a programba bevonásra került személyek esetében a fluktuáció mértékéröl és annak okáról (2.ábra) A foglalkoztatás kapcsán a fluktuáció tekintetében meghatározó a programba bevonásra kerültek száma, a programot elhagyók száma, illetve a programot befejezettek száma. A pályázati kiírás a két munkáltatónál összesen 75 fő foglalkoztatását tűzte ki célul, melynek megvalósulásaként a programba bevonásra kerültek létszáma 105 fö volt, a programot elhagyók száma 37 fö. A program elhagyásának okai a következők: Az egészségügyi alkalmassági vizsgálat során 11 személy kapott alkalmatlan minősítést. Egy fő a program során elhalálozott, további egy fő egészségügyi állapota olyan mértékben rosszabbodott, hogy a programban történő munkavégzést nem tudta a továbbiakban vállalni. 11 személy esetében az igazolatlan hiányzások következtében a munkáltató által történt a munkaviszony megszüntetésre. Hozzátartozó miatti ápolási díjat három személy igényelt és a továbbiakban nem vett részt a programban. Szintén három személy munkaviszonya közös megegyezéssel szűnt meg. A fluktuációt jelentős mértékben csökkentené a jelen juttatási rendszer továbbgondolása, illetőleg a munkában maradást elősegítené az is, ha a programot befejezők számára a nyolc órás közfoglalkoztatáson kívül több alternatíva, lehetőség lenne a továbbfoglalkoztatásra, hosszabb távú tervezésre.

\section{A változók leiró statisztikai jellemzése}

A vizsgált változók összefüggéseit feltáró statisztikai elemzések elött, az egyes mérőeszközök esetében normalitásvizsgálatot végeztünk. Kolmogorov-Smirnov teszttel igazoltuk, hogy a változók (étkezés, ruházkodás, lakhatás, eladósodottság, kommunikációs képesség, megjelenés, külső rendezettség, addiktológiai probléma, függőség, nehézség hivatalos ügyeinek intézésében,önállótlanság tájékozatlanság, egészségügyi probléma tartós orvosi kezelés alatt áll vagy arra szüksége lenne, családi párkapcsolati probléma, gyermek nevelés, válás, általános mentális személyiségbeli problémák, kiskorú gyermek elhelyezésének problémája idős hozzátartozó elhelyezésének problémája, fogyatékkal élő hozzátartozó elhelyezésének problémája, közlekedési eljutási nehézségek munkahelyre, magatartásbeli problémák, negatív munkavállalói attitüd, alapkészségek nehézségek írásban olvasásban, kommunikációban, munkavégző képesség, együttmüködési képesség,csoportba beilleszkedési készség) nem normál eloszlást követnek ( $\mathrm{p}<001$ minden esetben), ezért Mann Whitney U próbát, valamint Spearman-féle rangkorrelációt számoltunk minden változó esetében. Az idős hozzátartozó elhelyezésének, a kiskorú gyermek elhelyezésének, fogyatékkal élő hozzátartozó elhelyezésének problémáját az öt hónapban vizsgáltuk, a statisztikai elemzéseket elvégeztük, azonban mivel a vizsgált minta tekintetében nem relevánsak a fent említett problémák, ezért a további elemzéseknél ezeket nem vettük figyelembe. A statisztikai elemzéseket az IBM SPSS Statistics 21.0 program segítségével végeztük. Az eredményeket $\mathrm{p}<0,05$ esetén tekintettük szignifikánsnak.

\section{Eredmények}

A korrelációs összefüggések alapján elmondható, hogy néhány változó sok másik változó javulását is eredményezheti. A szignifikáns kapcsolatok mindegyike egyenes irányú, tehát egy változó esetében a javulás a másik változónál is javulást, a csökkenés pedig csökkenést eredményez. A ruházkodás-külső megjelenés, rendezettség közötti összefüggés iránya az elvártnak megfelelő, minél inkább javul a ruházkodás, annál inkább javul a külső megjelenés is. $\left(\mathrm{r}_{\mathrm{s}}: 0,298, \mathrm{p}=0,013\right) \mathrm{Az}$ additológiai probléma javulása sok tényező javulását eredményezi a korrelációs kapcsolatokat vizsgálva. Ennek megfelelően levonhatjuk azt a következtetést, hogyha az additológiai problémában javulást tapasztalunk, akkor az erőteljesen pozitív irányba befolyásolja az együttmüködési képességet, csoportba beilleszkedési készséget, 
$\left(\mathrm{r}_{\mathrm{s}}=0,496, \mathrm{p}=0,000\right)$ az egészségügyi problémák megjelenését, $\left(\mathrm{r}_{\mathrm{s}}=0,342, \mathrm{p}=0,004\right)$ az alapkészségeket, $\left(r_{s}=0,585, p=0,000\right)$ a kommunikációs képességet, $\left(r_{s}=0,614, p=0,000\right)$, a külső megjelenést, külső rendezettséget, $\left(\mathrm{r}_{\mathrm{s}}=0,257, \mathrm{p}=0,035\right)$. A korrelációs kapcsolatokat továbbvizsgálva láthatjuk, hogy az eladósodottság mértékének csökkenésével javulnak a lakhatással kapcsolatos mutatók $\left(\mathrm{r}_{\mathrm{s}}=0,278, \mathrm{p}=0,022\right)$, és pozitív hatással van az általános mentális állapotra is. $\left(\mathrm{r}_{\mathrm{s}}=0,296, \mathrm{p}=0,014\right)$. A kommunikációs képességek javulása javítja az együttmüködési képességet, csoportba beilleszkedési készséget $\left(\mathrm{r}_{\mathrm{s}}=0,659, \mathrm{p}=0,000\right)$ és természetesen az alapkészséget is rendkívül pozitív irányban befolyásolja $\left(r_{s}=0,803, p=0,000\right)$. A megjelenés, külső rendezettség korrelál a kommunikációs képességekkel $\left(r_{s}=0,339\right.$, $\mathrm{p}=0,010)$ valamint az egészségügyi problémák javulásával is. $\left(\mathrm{r}_{\mathrm{s}}=0,319, \mathrm{p}=0,008\right) . \mathrm{Az}$ egészségügyi problémák sok tényezőre hatással vannak, ezek közül a legnagyobb korrelációs kapcsolat a ruházkodással $\left(\mathrm{r}_{\mathrm{s}}=0,381, \mathrm{p}=0,001\right)$, a már említett additológiai problémával, valamint az alapkészségekkel $\left(\mathrm{r}_{\mathrm{s}}=0,297, \mathrm{p}=0,014\right)$, a kommunikációs képességekkel $\left(r_{s}=0,308, p=0,011\right)$ és a külső megjelenéssel kapcsolatban is $\left(r_{s}=0,319, p=0,008\right)$ korrelációs összefüggést fedezhetünk fel. A magatartásbeli problémák eröteljesen meghatározzák a személyek munkavégző képességét $\left(\mathrm{r}_{\mathrm{s}}=0,423, \mathrm{p}=0.000\right)$, kommunikációs képességeit is $\left(\mathrm{r}_{\mathrm{s}}=0,298, \mathrm{p}=0,014\right)$. Az alapkészségek javulása esetén elörelépést tapasztaltunk az együttmüködési képességben, csoportba illeszkedésben $\left(\mathrm{r}_{\mathrm{s}}=0,767, \mathrm{p}=0,000\right)$, valamint a kommunikációs készségben $\left(\mathrm{r}_{\mathrm{s}}=0,803, \mathrm{p}=0,000\right)$, hatására a magatartásbeli problémák, negatív munkavállalói attitüd is javult $\left(\mathrm{r}_{\mathrm{s}}=0,304, \mathrm{p}=0,012\right)$. Az együttmüködési képesség, csoportba beilleszkedés jelentős javulást eredményez a munkavégző képességben $\left(\mathrm{r}_{\mathrm{s}}=0,370\right.$, $\mathrm{p}=0,000)$, magatartásbeli problémákban $\left(\mathrm{r}_{\mathrm{s}}=0,370, \mathrm{p}=0,000\right)$, kommunikációban $\left(\mathrm{r}_{\mathrm{s}}=0,659\right.$, $\mathrm{p}=0,000)$, a hivatalos ügyek intézésével $\left(\mathrm{r}_{\mathrm{s}}=0,284, \mathrm{p}=0,019\right)$, alapkészségek javulásával $\left(r_{s}=0,767, p=0,000\right)$. is összefüggésbe hozható. A program megvalósítási idejét tekintve, július és november hónap eredményeit vizsgálva szignifikáns különbséget tapasztaltunk az étkezés $(\mathrm{p}<0,001)$, a kommunikációs képesség $(\mathrm{p}<0,001)$, az additológiai probléma $(\mathrm{p}<0,001)$, az egészségügyi probléma $(\mathrm{p}=0,004)$, a családi- párkapcsolati probléma $(\mathrm{p}<0,001)$, az idös hozzátartozó elhelyezésének problémája $(p=0,007)$ a közlekedési, eljutási nehézségek a munkahelyre $(\mathrm{p}=0,048)$, alapkészségek $(\mathrm{p}<0,001)$, valamint az együttmüködési képesség, csoportba illeszkedési készségek $(\mathrm{p}<0,001)$ esetében.

Megvitatás: A jóllétnek mind a munkavállalók szubjektív érzelmi átéléseire, mind munkahelyi teljesítményükre pozitív hatása van, ezért a társadalomnak érdemes kiemelt figyelmet fordítania a munkáltatók érzékenyítésére, a komplex támogatási csomagot biztosító programok kialakítására, a munkavállalók életminőségének javulását meghatározó munkahelyi tényezők biztosítására.

\section{Élet a program után}

14 fő a program befejezését követően képzésben vett részt, 5 föt a program ideje alatt vett át a munkáltató nyolc órás közfoglalkoztatott állományba, 17 fö pedig a program végén került átsorolásra. Hat fö a program befejezését követően nyílt munkaeröpiacon talált munkalehetőséget, majd az utókövetés szakaszában további öt fö helyezkedett el sikeresen a nyílt munkaerőpiacon. A program munkavégzéshez kötődő fázisa 2016. november 30-án lezárult, majd december 31-ig utókövetési szakasz keretében tartottuk a kapcsolatot a programba bevonásra került személyekkel. Ebben az időszakban került kitöltésre egy kérdőív, melyben többek között a programhoz kötődő szolgáltatásokkal kapcsolatosan arra kértük a kérdőívet kitöltőket, hogy emeljék ki a véleményük szerint leginkább pozitív tartalommal bíró szolgáltatási elemeket. 
A kitöltés eredményeként a legtöbbször, 22 esetben került kiemelésre az ügyintézések segítése, melyet 21 alkalommal az étkezés, majd 20 alkalommal a mentori illetve az orvosi segítségnyújtás igénybevétele követte. 9 alkalommal történt kiemelésre a munkalehetöség, míg 4 alkalommal az információhoz jutás lehetősége.(7.táblázat)

7. táblázat. A program során a résztvevök által kiemelt szolgáltatások. (forrás: a Szerzö).

\begin{tabular}{|l|r|}
\hline \multicolumn{1}{|c|}{ Szolgáltatások } & db \\
\hline Étkezés & 21 \\
\hline Információ & 4 \\
\hline Ügyintézés & 22 \\
\hline Munkalehetőség & 9 \\
\hline Orvos & 20 \\
\hline Mentor & 20 \\
\hline
\end{tabular}

A kérdőív során megkérdezésre került az is, választási lehetőségeket kínálva hogy, melyek azok az elemek amelyek leginkább hiányoznak a program befejezését követően. A kapott válaszok alapján a leginkább hiányzó elemként a hasznosság érzését emelték ki 40 esetben, míg 34 esetben a rendszeres meleg étkezést jelölték meg. Aki meghallgatott, segített 30 alkalommal került megjelölésre, 28 alkalommal a munkatársak hiányát jelölték meg, 21 alkalommal a munka, feladat hiányzik leginkább, 13 esetben a napi rendszeresség, 3 megjelölést a melegben voltam lehetőség kapott, míg a sort 2 kiemeléssel a kiszámíthatóság, tervezhetőség zárta. A munkaruha hiánya nem került megjelölésre a válaszadások során.(8.táblázat)

8.táblázat: Mi az ami leginkább hiányzik Önnek a program befejezését követöen?(forrás: a Szerzö)

\begin{tabular}{|l|r|}
\hline \multicolumn{1}{|c|}{ Programelem } & Alkalom (db) \\
\hline Napi rendszeresség & 13 \\
\hline Rendszeres meleg étkezés & 34 \\
\hline Hasznosság érzése & 40 \\
\hline Munkatársak & 28 \\
\hline Munka, feladat & 21 \\
\hline Melegben voltam & 3 \\
\hline Kiszámíthatóság, tervezhetőség & 2 \\
\hline Munkaruha & 0 \\
\hline Aki meghallgatott, segített & 30 \\
\hline
\end{tabular}

\section{Következtetés}

Sok esetben az orvosi alkalmassági vizsgálaton a munkavégzésre alkalmatlannak minősített személyek esetében és a tanácsadások során feltárásra került, az előzetes orvosi diagnózisok és az elmondottak alapján indokolt lenne a megváltozott munkaképesség megállapítását meghatározó eljárás elindítása. Azonban a pénzbeli ellátás csak meghatározott munkaviszony leigazolását követően kerül megállapításra, így ezek az emberek csak az egészségkárosodási és gyermekfelügyeleti támogatásra szerezhetnek jogosultságot amelynek összege 
jövedelemmel nem rendelkező egyedül élő személy esetében az öregségi nyugdíj mindenkori legkisebb összegének (2017-ben 28.500 Ft) $92 \%$-a, 2016-ban 26.220 Ft.

Munkavégzés esetén az ellátást szüneteltetni kell. (62/2006. (III. 27.) Korm. rendelet az egyes pénzbeli szociális ellátások elszámolásának szabályairól. ${ }^{x i i}$ Az ügyfelek esetében fontosnak tartom leírni, hogy a program kezdetekor meglehetősen negatív volt a hozzáállásuk, passzivitás jellemezte a résztvevők többségét. Nagyfokú bizalmatlanság jellemezte a csoport nagy részét, nem hittek a segítő szándékunk valódiságában, ezért a program elején kapott háttér információk a program elörehaladtával egyes esetekben nagymértékben változtak. Ezek visszavezethetők többek között a korábbi negatív tapasztalatokra, a programba kerülés idején jellemző szociális helyzetre. A problémáikról is némely esetben jóval később, a bizalmi kapcsolat megszilárdulását követően számoltak be.

Több esetben felderítésre került nagymértékü adósság: Tb nem fizetés, lakbérhátralék, közüzemi számlák hátraléka, egyéb adósságok. A tartós munkanélküliség miatt, sokaknál jelentősen leépült a munkavégző képesség, és számos esetben a szociális készségekre is elmondható ugyanez. Az egyéni beszélgetések során a szociális helyzetfelméréshez a kérdésekre adott válaszok nem mindig helytállóak. Nem tudják megmondani hány év munkaviszonnyal rendelkeznek, milyen jellegü foglalkoztatásban dolgoztak utoljára és mikor. Az ellátások neveit összekeverik. A kezdeti nehézségek közé tartozott, az alapvető közösségi szabályok tisztázása és betartásának elősegítése, a társadalmi és a munkahely, munkavégzés szempontjából szükséges normák betartása. Azonban az idő előrehaladtával ezek egyre kevesebb személynél jelentkeztek, a munkavégzéshez szükséges kompetenciák kialakultak, a társadalmi normák egyre inkább beépültek a mindennapokba.

Kisebb konfliktusok a program egésze alatt elöfordultak, azonban ezek csoporton belül rendezésre kerültek, a sikeres megoldás elősegítette a csoportok összekovácsolódását, amelyet aztán többen meg is jegyeztek a résztvevő személyek közül. Ez fontos momentuma, mérföldköve volt ennek a néhány hónapnak, hiszen a biztonságérzetükre, önbecsülésükre, ezáltal teljesítményükre is pozitívan hatott. Az állandóság, ami a munkafolyamatokat jellemezte, sikerélményekkel gazdagította a dolgozókat és pozitív irányba mozdította el a személyiségüket. A támogatásokkal kapcsolatos ügyintézésben sok segítséget nyújtottak a mentorok, ezzel hozzájárulva a szociális háttér javításához. A programban lévő munkavállalók az ügyintézésekkel kapcsolatban és a hétköznapi életben is magabiztosabbá váltak. Néhányan a későbbiekben igyekeztek egyedül elintézni az ügyeiket, az önálló ügyintézésre való törekvésüket ösztönöztük is a program során, azonban egyes személyek esetében megállapítható, hogy mentális állapotuk sajnos nem teszi ezt lehetővé. A pilot speciális közfoglalkoztatási programba kerülő személyek hátterével, problémáival kapcsolatosan már az előzetes tanácsadások során is szembesültünk, hogy mennyire komplexek, sokrétüek és szerteágazók. Néhány személytől eltekintve családi hátterük rendezetlen, az elmúlt évtizedek foglalkoztatáspolitikájának következményeként a társadalom szélén lévő, kirekesztett személyekről van szó. Elmondható, hogy abszolút mértékben a túlélésre rendezkedtek be. Életvitelüket a távlati perspektíva teljes hiánya jellemzi, naprólnapra történő terveznek, amelynek megoldására sajnos ez a program sem képes, azonban úgy vélem, hogy számos alapvető probléma és a továbbiakban továbbgondolásra alapot nyújtó információ került rögzítésre.

Azok az ügyfelek, akik ténylegesen valamilyen egészségügyi problémával küzdenek és emiatt nem tudtak elhelyezkedni, pozitívan értékelték a lehetőséget, ez megmutatkozott a munkafegyelemben, a szabályok betartásában. Azok, akik nem küzdenek egészségügyi problémával és eddig ellátásuk is volt (Foglalkoztatást helyettesítő támogatás), kevésbé motiváltak az alacsony bér miatt. Néhány személy számára az öt hónap is jelentős előrelépést jelentett, mind az anyagiak terén, mind pedig a szociális helyzetük terén, ez föként azokra igaz, akik a programba kerülést megelőzően nem részesültek ellátásban. Azok, azonban akik 
programba kerülésük előtt foglalkoztatást helyettesítő támogatásban részesültek, rendkívül kevésnek tartották a kapott juttatást, mely néhány ezer forinttal haladta meg a segélyt. Esetükben szélmalomharcnak bizonyult az érvelésünk, mely szerint nő a munkaviszonyban eltöltött idő, kapnak étkezést, számos plusz juttatást (segélyeket) igényeltünk, a program továbblépési lehetőség a foglalkoztatás szempontjából. Szemben állt ezzel a foglalkoztatottak perspektívája, mely szerint az ismerőseik „kiröhögik” őket, amiért ennyi pénzért dolgoznak, nem tudnak elmenni „maszekba”. A társadalmi környezet, amelyből érkeztek, nagymértékben befolyásolta és hatott a munkavégzésükre, munkamoráljukra is.

A speciális közfoglalkoztatási program végéhez közeledve, kétoldalú megállapodás keretében kiválasztásra kerültek azok a személyek, akiket a munkáltatók a program befejezése után is alkalmazni kívántak. Ez fordulópontot jelentett, mivel a résztvevők közül néhányan nehezen fogadták el a program végét, és azt, hogy számukra véget ér a foglalkoztatás. Ez egyesekből negatív érzéseket váltott ki, kétségbeesést, csalódottságot és elkeseredést tapasztalhatunk annak ellenére is, hogy az egyéni és csoportos tájékoztatások keretében is ismertetésre kerültek az aktuális munka- és tanfolyami lehetőségek. Felajánlottuk a segítségnyújtást a munkahelykereséshez, önéletrajzokat készítettünk, valamint felajánlottuk a továbbiakban történő kapcsolattartást. Az alkoholfogyasztás problémájának felerösödése valószínüleg ez miatt is ismételten előtérbe került. A program elején tapasztalt negatív világnézet és kilátástalanság, fóként a depresszióra hajlamos egyéneknél egyre inkább felerősödött.

A kérdöív által összegzett eredményekből jól látszik, hogy legtöbb alkalommal került kiemelésre a hasznosság érzésének hiánya a program befejezését követően, szintén magas a meleg étkezés hiányának megemlítése és ezek mellett kiemelném a munkatársak valamint a munkavégzés, feladat hiányának megemlítését. A programba bevonásra került személyek legalább 12 hónapja nem dolgoztak a bevonás előtt az eredményekből azonban jól látszik, hogy már az öt hónap is elégnek bizonyult annak tekintetében, hogy a hasznosan töltött idő, a rendszeresség, és a munkakapcsolatok hiányozzanak a résztvevők életéből. Még a foglalkoztatók által továbbfoglalkoztatottak esetében is indokoltnak tartanánk a program keretében biztosított egy hónap utókövetésen túli, hosszabb távú mentális segítségnyújtást, támogatást.

Szükségét éreznénk, egy a speciális és normál közfoglalkoztatás között megvalósuló programnak, vagy esetlegesen néhány személy esetében a mentori szolgáltatás hosszabb távú biztosításának, ezzel mintegy biztosítva, hogy a program végére valamennyi ügyfél, ha akarja, akkor kapja meg a lehetőséget a továbblépésre. Az azonban a célcsoport tekintetében megjegyzendő, a jelen programba bevonásra került személyek egy részére jellemző, hogy reális esélye a továbbfoglalkoztatásuknak csak speciális közfoglalkoztatásban képes hosszabb távon megvalósulni. A kapcsolattartással próbáljuk elérni, hogy azok, akik kikerülnek a programból, ne sodródjanak, ne szakadjanak el a társadalomtól. Itt azonban megjegyeznénk, hogy meglátásunk és eddigi tapasztalatunk szerint ezt a munkát hatékonyan végezni csak olyan személy képes, aki stabil, pozitív és támogató személyiséggel rendelkezik. Hitelesen azonban meglehetősen nehéz úgy jövőképet kialakítani és formálni, hogy a segítő szakember maga is teljesen bizonytalan a saját jövőbeli foglalkoztatottságát illetően. Véleményünk szerint többféle alternatíva is létezhet a probléma megoldására, egyik ilyen megoldás lehetne a pilot program, mint első lépcsőfok, melyből továbblépési lehetőség lenne a normál közfoglalkoztatás vagy valós munkaerő piaci igényeknek megfelelő átképzés lehetősége, melyet követhetne a továbbfoglalkoztatás vagy egyéb elsődleges munka eröpiaci reintegráció lehetősége, melyet a munkáltatói oldal felöl esetleges bértámogatással, egyéb kedvezményekkel ösztönözve lehetne biztosítani. A meghatározott célok elérése érdekében azonban elengedhetetlen a programban résztvevők közös, együttes és összehangolt munkája. 


\section{Konklúziók}

Összességében megállapítható, hogy jelentős aktivitást eredményezett a munkanélküliek között a pilot program elindítása, sok szempontból mentális javulást is teremtett az új munkahelyi környezet, az új közösség, a tanácsadások során feltárásra kerültek a továbblépés lehetőségét biztosító megoldási alternatívák. A program pozitív hatása a foglalkoztatási helyzet javításában is megmutatkozott, hiszen a bevont személyek közül a tanácsadások és a mentor segítségnyújtás következményeként több résztvevő a versenyszférába, helyi önkormányzatok foglalkoztatásába, valamint közmunka programokba is felvételre került. A program bebizonyította azt is, hogy fellelhetök olyan hátrányos helyzetü, nehezebb sorsú emberek, akik bár segítséggel és irányítással, de visszavezethetők a munka világába. Azok az emberek is lehetöséget kaptak a speciális program által, akik az elsődleges munkaerő piacon, sőt még a hagyományos közfoglalkoztatás keretében sem lennének képesek átmenetileg, vagy tartósan munkavégzésre, másrészt olyan rétegek is bevonásra kerültek a programba, akik eddig minimálisan, vagy egyáltalán nem dolgoztak semmilyen formában. Bár a közfoglalkoztatás gyakran képezi vita tárgyát a politikai közbeszédben, azonban számos esetben ez az egyetlen lehetősége a kiúttalan, jövőtlen embereknek, hogy hasznosnak érezhessék magukat és kapcsolódni tudjanak a saját közegük mindennapi életébe. A pilot speciális közfoglalkoztatási programban résztvevő közfoglalkoztatottak a közös teherviselés mellett részt vehettek azokban a mindennapi szokványos élethelyzetekben is, hogy van kötelezettségük, fel kell kelniük reggel, el kell menniük dolgozni.

\section{Jogszabályok}

1040/2016. (II.11.) Kormány határozat, a közfoglalkoztatás 2016. évi céljairól és a közfoglalkoztatás szempontjából kiemelt települések meghatározásáról 2.d) (2016.06. 08.)

Web: http://www.kormány.hu (Letöltés:2016.07. 01.)

1991. évi IV. törvény a foglalkoztatás elősegítéséröl és a munkanélküliek ellátásáról 40.§ (2016.07.10.)

Kötelező egészségbiztosítás ellátásairól szóló 1997. évi LXXXIII. törvény (2016.11.05.)

217/1997. (XII.1.) Kormány rendelet a kötelező egészségbiztosítás ellátásairól szóló 1997. évi LXXXIII. törvény végrehajtásáról (2016.11.05.)

1253/2016.(VI.6.) Kormány határozat a mentális, szociális vagy egészségügyi okból foglalkoztatásba be nem vonható álláskeresők foglalkoztathatóságának növelését szolgáló 2016. évi kormányzati intézkedésekről (2016.11.14.)

170/2011.(VIII.24.) Kormány rendelet a közfoglalkoztatási bér és a közfoglalkoztatási garantált bér megállapításáról (2016.11.23.)

375/2010.(XII.31.) Kormány rendelet a közfoglalkoztatáshoz nyújtható támogatásokról (2016.11.23.)

1990. évi LXV. törvény a helyi önkormányzatokról 7. § (2016.11.23.)

1997. évi LXXXIII. törvény a kötelező egészségbiztosítás ellátásairól 83. § (2016.11.05.)

(62/2006. (iii. 27.) Kormány rendelet az egyes pénzbeli szociális ellátások elszámolásának szabályairól.(2016.07.10.) 


\title{
A TANULÁSI MOTIVÁCIÓK ÉS A MUNKAERŐ-PIACI ELVÁRÁSOK ÖSSZEFÜGGÉSEI
}

\section{Szerzők:}

Pálosi Rita

Debreceni Egyetem

R. Fedor Anita

Debreceni Egyetem Egészségügyi Kar

Első szerző e-mail címe:

rita.palosi@gmail.com

\section{Lektorok:}

Horváth László

Debreceni Egyetem

Jávorné Erdei Renáta

Debreceni Egyetem

Szilágyi Barnabás

Debreceni Egyetem

Mező Katalin

Debreceni Egyetem

Pálosi Rita, R. Fedor Anita (2017): A tanulási motivációk és a munkaerö-piaci elvárások összefüggései. Különleges Bánásmód, III. évf. 2017/4. szám, 51-63. DOI 10.18458/KB.2017.4.51

\begin{abstract}
Absztrakt
A tanulási motivációról hazai és külföldi szakirodalomban egyaránt olvashatunk. Jelen tanulmányban mi is azt vizsgáljuk, hogy milyen a fiatalok tanulási attitüdje illetve, hogy ez milyen összefüggésben van a fiatalok munkaeröpiacon történő elhelyezkedésével. A téma aktualitását az adja, hogy a pályaválasztás elött álló fiatalok többnyire felsőfokú képzésekre jelentkeznek, és szakmát kevesebben akarnak tanulni. Valóban mindenki ennyire motivált a tanulásban? Melyek azok a belső és külső tényezők, amelyek motiválják az egyént a tanulásában? Vajon a családi háttér hatással van-e a tanuló teljesítményére? Ezekre a kérdésekre kerestük a választ. Eredmények: Elsődleges eredményeink szerint a vizsgált fiatalok jelentős többsége szeretne továbbtanulni az érettségi után. Ebben látják későbbi munkaerő-piaci érvényesülésüket. A legtöbbek által megjelölt szakirány az egészségügyi és a gazdasági terület. Tanulási motivációs rangsoruk első helyén a „sikeres akarok lenni” attitüd áll.
\end{abstract}

Kulcsszavak: tanulási motiváció, munkaerőpiac, ifjúság

Diszciplína: pedagógia, pszichológia, szociológia,

\section{Abstract}

Publications on student motivation in learning are available in Hungarian as well as in English-language scientific literature. The present study is aiming to focus on the connection 
between motivation of learning and finding work at the labor market. Actuality of the topic is based on the fact that young people in front of a career choice mostly apply for higher education and there are only fewer of them willing to learn a profession. Is everyone really that motivated to learn? What are the external and internal factors that motivate the individual to learn? Does family background have an impact on the performance of the student? We have been looking for answers to these questions. According to our primary results, the majority of the examined young adults are willing to continue to study after high-school graduation. That is how they think they will later prevail entering the labor market. The most common specializations chosen are health and economy. At the first place of their learning motivation ranking we find "want to be successful attitude".

Keywords: motivation in learning, factors in learning motivation, youth

Disciplines: pedagogy, psychology, sociology,

\section{BEVEZETÉS}

Írásunkban a fiatalok tanulási motivációjának feltérképezésére vállalkozunk. A témához kapcsolódó elméleti háttér felvillantása után, a jelenleg is folyamatban lévő empirikus munkánk eddigi eredményeit kívánjuk bemutatni. Kutató munkánkban a fiatalok, ezen belül is a végzés előtt álló középiskolások tanuláshoz kötődő attitüdjét, munkaerő-piaci elvárásait, értékválasztását vizsgáljuk Debrecenben.

Tanulmányunkban elsősorban a tanulási motiváció kérdéskörére koncentrálunk, a munkaerö-piaci elvárások mintázatáról ennél rövidebben szólunk, az értékválasztással kapcsolatos eredményeinket pedig egy későbbi írásunkban közöljük. Vizsgálatunkkal egy korábbi nemzetközi kutatáshoz kapcsolódtunk (Youth in Central and Eastern European CrossborderAreas), melynek adatfelvétele egy-egy határ menti lengyel, ukrán, magyar településen történt, végzés előtt álló gimnazista és középiskolás fiatalok körében. Magyarországon Nyíregyháza lett a kiválasztott település. ${ }^{1}$ Az említett nemzetközi kutatás kérdőívét részben adaptáltuk, mely a későbbiekben lehetővé teszi számunkra, hogy a vizsgálat hazai vonatkozású eredményeit összevessük kutatásunk eredményeivel. Mintánkba két gimnázium került be (egy „általános”- és egy szakgimnázium), melyek 11. osztályos hallgatói körében teljes körü lekérdezést végeztünk.

Az adatgyüjtés 2017 májusában történt, kvantitatív, survey módszerrel. A két iskolában 100100 kérdőív került kiosztásra, mely 44 kérdést tartalmazott, melyből jelenlegi munkánkban 17 kérdés elemzésére koncentrálunk. A kérdések a következő dimenziók köré csoportosultak: Tanulási motiváció, Személyiség jegyek, Munkaerő-piaci elvárások, Családi dimenzió. Jelen írásban az ,általános” gimnázium adatait elemezzük, tanulmányunkban a hozzájuk kapcsolódó eredmények olvashatók. A teljes minta vizsgálata jelenleg is folyamatban van, melynek eredményeit a későbbiekben kívánjuk publikálni.

Az adatok rögzítésére és elemzésére az SPSS 24 statisztikai programot használtuk ${ }^{2}$. Ezen belül az adatok tényszerü leírását egyszerü megoszlás, az összefüggések vizsgálatát kereszttábla illetve Khi-négyzet próba segítségével végeztük el.Az ,általános” gimnáziumból beérkező kérdőívekből 88 volt értékelhető. A válaszadók közül 54 fő nő 32 fö férfi volt (2 fö nem válaszolt). A megkérdezett fiatalok többsége Debrecenben él (78 fö), faluról összesen 8 fö származik (2 fő nem válaszolt).

\footnotetext{
${ }^{1}$ A hazai adatokat Kovács-Dusa-Ludescher (2016), valamint Engler-R.Fedor-Markos (2016) elemezte a külföldi munkavállalás, regionális kötődés, szabadidős tevékenység, továbbtanulás, életcélok témában.

${ }^{2}$ Ezúton szeretnénk köszönetet mondani Kósa Szilviának az adatok SPSS-programban történő rögzítésért.
} 


\section{A tanulási motiváció}

Vizsgálatunk elméleti háttere multidiszciplináris, hiszen a témának pedagógiai, pszichológiai, szociológiai, élettani aspektusai is vannak. Írásunkban terjedelmi okok miatt nem vállaljuk az elméleti háttérként szolgáló valamennyi megközelítés teljes körü bemutatását, e tekintetben inkább egyfajta ízelítőként szolgálunk.

\section{Történeti áttekintés}

XVII. században Comenius azt gondolta, hogy „minden iskola játszóhellyé lehet, vagyis a tanítás és tanulás minden feladat játékként és tréfaként hajtható végre" (Réthyné, 2003, 12.o.). Szintén ebben a században élt és munkálkodott Locke, aki azt vallotta, hogy a gyermeki kíváncsiság „,nem egyéb, mint vágyódás a tudás után, épp ezért fel kell karolni' (Réthyné, 2003, 12.o.). Amint haladunk az időben elöre a 18. század francia felvilágosodás nagy alakja, Rosseau, aki a gyermeki kíváncsiságot helyezte középpontba, mely szerinte engedni kell a gyermeket, hogy ő maga oldja meg a kérdéseket. XIX. századi polgári pedagógiában Herbart hatását érezhetjük, aki felfedezte a kognitív motiváció lényegét, az ,érdeklődés az egyetlen olyan eszköz, amellyel tartóssá tehetjük az oktatás eredményét.'(Réthyné, 2003, 13.o.). Diesterweg a tudás iránti vágy és a tanulás szeretetére fókuszált. Ahhoz, hogy ezt az érzetet a tanulóban kiváltsa, a pedagógust ösztönzi arra, hogy tanítását tegye vonzóvá, érdekessé a diák számára.

A felsorolt gondolkodók tehát úgy vélekedtek, hogy a gyerekekben él a tudás iránti vágy, azonban ennek fennmaradása, fenntartása nagymértékben függ a tanároktól, szülőktől.Hazai viszonylatban meg kell említeni Nagy László munkásságát, aki felismerte az érdeklődés motiváló szerepét a tanításban, mely szerint, ha van, az ösztönszerüen elindítja az ismeretlen utáni vágyakozást, ami létrehoz egy ismeret folyamatot.

\section{Pszichológiai megközelités}

$\mathrm{Az}$ evolúciós pszichológia egyik kiemelkedő alakja Charles Darwin (1809-1882) elméletének a lényege, hogy a természetben az élőlények versengenek egymással a fennmaradásért. Freud Sigmund pszichoanalitikus megközelítése szerint, a motivációk a személyes múltban, élettörténetben gyökereznek és felnőtt személyiséget is teljes mértékben a gyermekkori tapasztalatok határozzák meg. A drive elméletek kidolgozója Clark Leonard Hull (1884-1952) a Yale Egyetem professzora. Ezek olyan motivációs elméletek, melyek a belső tényezők fontosságára helyezik a hangsúlyt. Drive szó jelentése ösztönöz, hajt, irányít, müködtet (Fodor, 2007)

\section{Szociológiai megközelités}

A tanulási motiváció és eredményesség nagymértékben függ a környezeti hatásoktól. A családi háttér e területen való jelentőségét több vizsgálat is alátámasztotta. Coleman (1996) szintén amellett érvel, hogy a családi háttér jellege meghatározza a gyermek későbbi teljesítményét. Ezen belül kiemeli a család jövedelmi-, vagyoni helyzetét, második tényezőként az emberi tőkét, mely a szülők iskolai végzettségét takarja, harmadik összetevőként a társadalmi tőkét említi, mely leginkább a szülők gyermekeikre fordított idő és energia mennyiségében mérhető. Jelen írásunkban elsősorban a szülök emberi tőkéjét vesszük figyelembe, mint a gyerekek tanulási motivációjának prediktorát.

\section{Élettani megközelités}

Amennyiben az anatómiai viszonyokban akarjuk elhelyezni a motivációt akkor azt, kell tudnunk, hogy a limbikus rendszer (1. ábra) felelős az érzelmeinkért. Az általános motivációs 
állapot jelentős szerepet játszik a viselkedésünkben, melynek anatómiai-élettani alapja a formatio retikularis. Kísérletek igazolták, hogy a vegetatív idegrendszer bizonyos tünetekkel válaszol a motivált állapotra. Ilyen például a vérnyomás emelkedés, szapora légzés-és pulzus szám, pupillatágulat, adrenalin-és vércukor szintemelkedés, melyek által a szervezet az energiáit mozgósítja.

\section{1. ábra: Limbikus rendszer (forrás: kekneveles.net)}

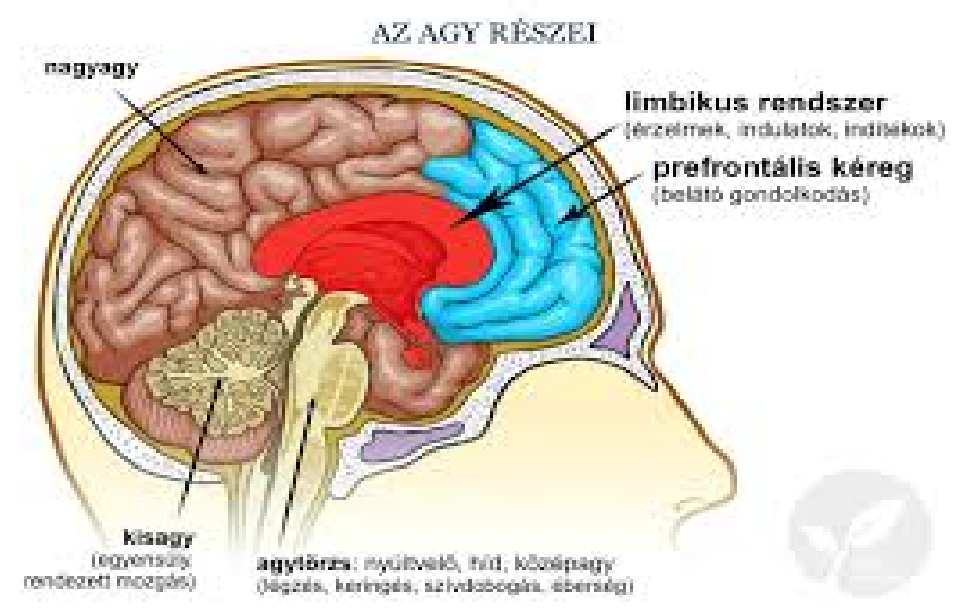

A tanulási motiváció külső és belső tényezőit ismeri a szakirodalom. Ennek bemutatásához Réthyné tipizálásához nyúlunk vissza. Írása szerint:' 'belső (intrinzik) tanulási motivációról akkor van szó, ha a motivált állapot a tanulók meghatározott személyiségjegyei vagy a tanulási helyzet sajátosságai révén jön létre. Külső (extrinzik) tanulási motiváció fennállása esetén a tanulás a ülső, kivülröl ható, magától a tanulási tevékenység lényegétől idegen,a konkrét cél előtt meghúzodó célokért történik", (Réthyné, 2003, 117-118o.)

\section{AZ EMPIRIKUS VIZSGÁLAT EREDMÉNYEI}

Kutatásunkban a fentebb említett külső és belső motívációk feltárására a következő kérdést tettük fel: „Melyek azok a tényezők, amelyek szerepet játszanak a tanulásodban?”.Arra kértük a tanulókat, hogy a felsorolt lehetőségek közül a három legfontosabb tényezőt jelöljék meg. A lehetséges első öt válasz a külső, míg a fennmaradó három a belső motiváló tényezők csoportjába tartozik. Láthatjuk a válaszok alapján, hogy a megkérdezett tanulók döntő többségét egy belső erő hatja a tanulásban, amely nem más mint a köteleségtudat és a sikeressé válás. Azonban kiemelendő a jó jegyek jelentősége, amely igen motiváló jelentőséggel bír a tanulók teljesitményében. Itt emelnénk ki a hatékony pedagógus szerepét. A jó jegy, a dicséret, a jutalom, mint extrinzik faktor mega erővel hathat a diák munkájára. (2.ábra)

2.ábra. Melyek azok a tényezők, amelyek szerepet játszanak a tanulásodban? (fö). (forrás: Pálosi és R. Fedor 2017 saját vizsgálat) 


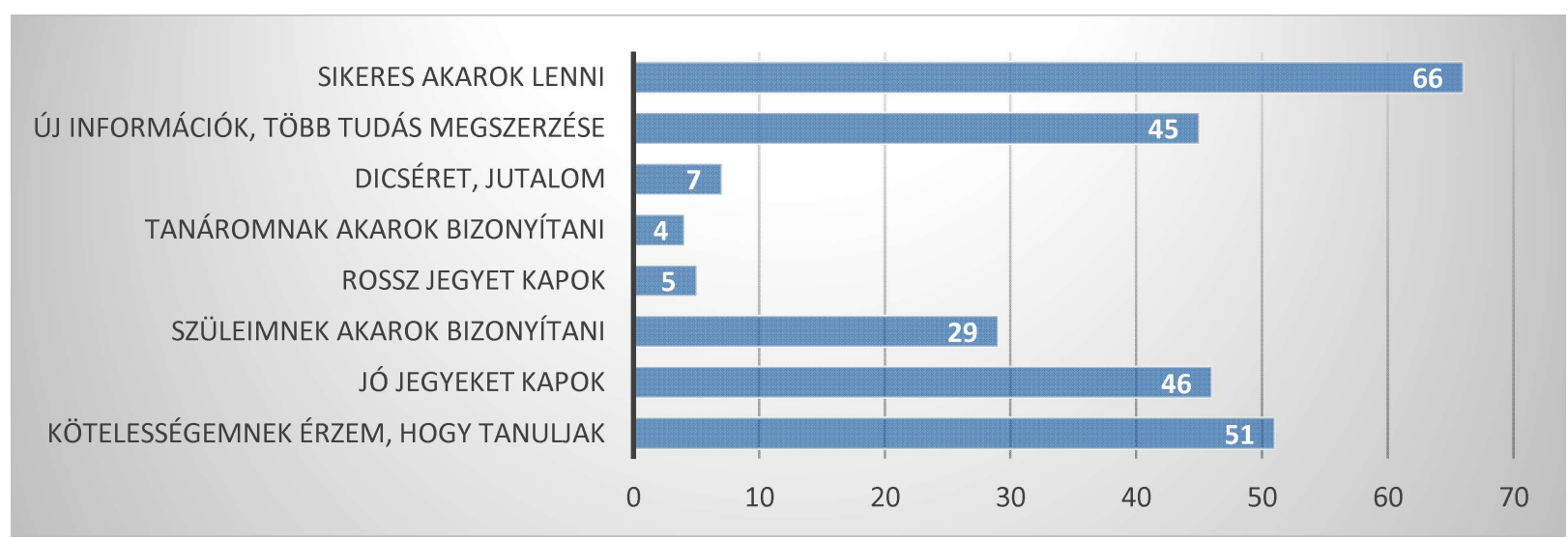

A következő három kérdés, mely a tanuláshoz kapcsolódó motivációs tényezőkön belül a tárgyi dolgokra kérdez rá, szintén ezt a gondolatmenetet követi. A megkérdezettek 57\%-nak nem tettek ígéretet a szülei, családtagjai a jó tanulmányi éredményeiért illetve nem is várják el a fiatalok, hogy bármiféle jutalomban is részesítsék öket. Azonban 32\%-nak azt ígérték a szülők, hogy a jó teljesítményét honorálják, ugyanakkor az ehhez a csoporthoz tartozó fiatalok nem tarják fontosnak a tárgyi jutalmat. Pozitív csalódás ez a mai anyagias világba, ahol minden arról szól, hogy ha valamit csinálunk azért honorárium jár. (3.ábra)

3.ábra. Tettek-e valaha igéretet szüleid,családtagjaid, rokonaid,hogy amennyiben jól tanulsz kapsz valamit?(forrás: Pálosi és R. Fedor 2017 saját vizsgálat)

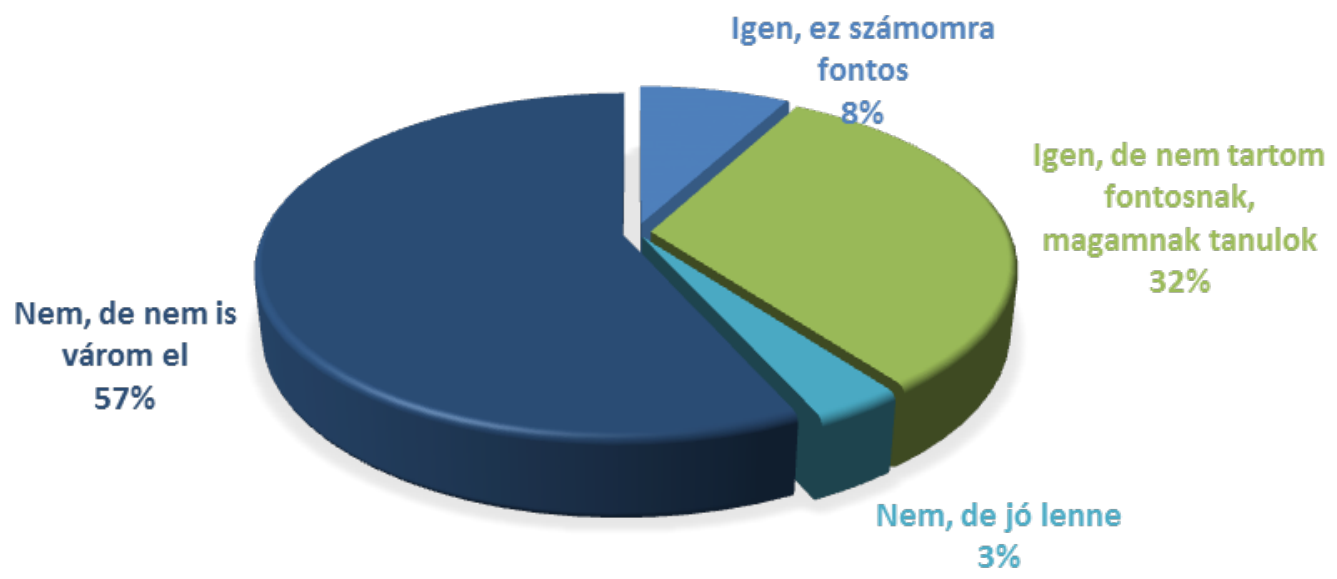

Nyitott kérdésben vártuk a válaszok széles skáláját, a tekintetben, hogy mi mindent fognak felsorolni a válaszadó diákok, amelyeket jutalomként adhat egy szülő a gyermekének ha kiemelkedően teljesít. A 88 föből, 65 nem válaszolt erre a kérdésre azaz, gyakorlatilag 65 fö semmilyen jutalmat nem kap teljesítményéért. A maradék 23 fó válaszaitból kiderül hogy a tárgyi dolgok, mint a pénz a ruha mellett megjelent a dicséret is.

Mindezek ismeretében, rákérdeztünk a tanulók tanulmányi eredményeire is. Azt kértük, hogy az utolsó félévet vették figyelembe. A diákok közül mindösszesen egy fó volt, aki a közepes érdemjegyet jelölte meg. 25 fö kitünő, 36 jeles és 22 tanuló jó minősítéssel büszkélkedhet, 4 fö nem válaszolt. Ezen a ponton érdemes megemlíteni, hogy a válszadó 
fiatalok, kiemelkedő átlagostanulmányi eredményt produkáló gimnázium tanulói, ezért vizsgálatunk eredményei nem általánosíthatóak a végzős fiatalok teljes csoportjára.

Arra a kérdésre, hogy elégedett-e a tanulmányi eredményeivel 30 fó nemmel válaszolt. Ami azt jelentheti, hogy a jeles tanulók körében is akadnak diákok, akik még jobb teljesítményre vágynak.

Arra is kiváncsiak voltunk, hogy mennyire elégedettek az életükkel a diákok. Válaszaikból a következők derülnek ki: Összeségében a megkérdezett fiatalok jelentős többsége elégedett az életével. 39\% nagyon, 51\% az inkább elégedett kategóriát jelölte meg. 8\%-uk inkább nem vagy egyáltalán nem elégedett (4.ábra).

4.ábra.Összeségében mennyire vagy elégedett az életeddel?(forrás: Pálosi és R. Fedor 2017 saját vizsgálat)

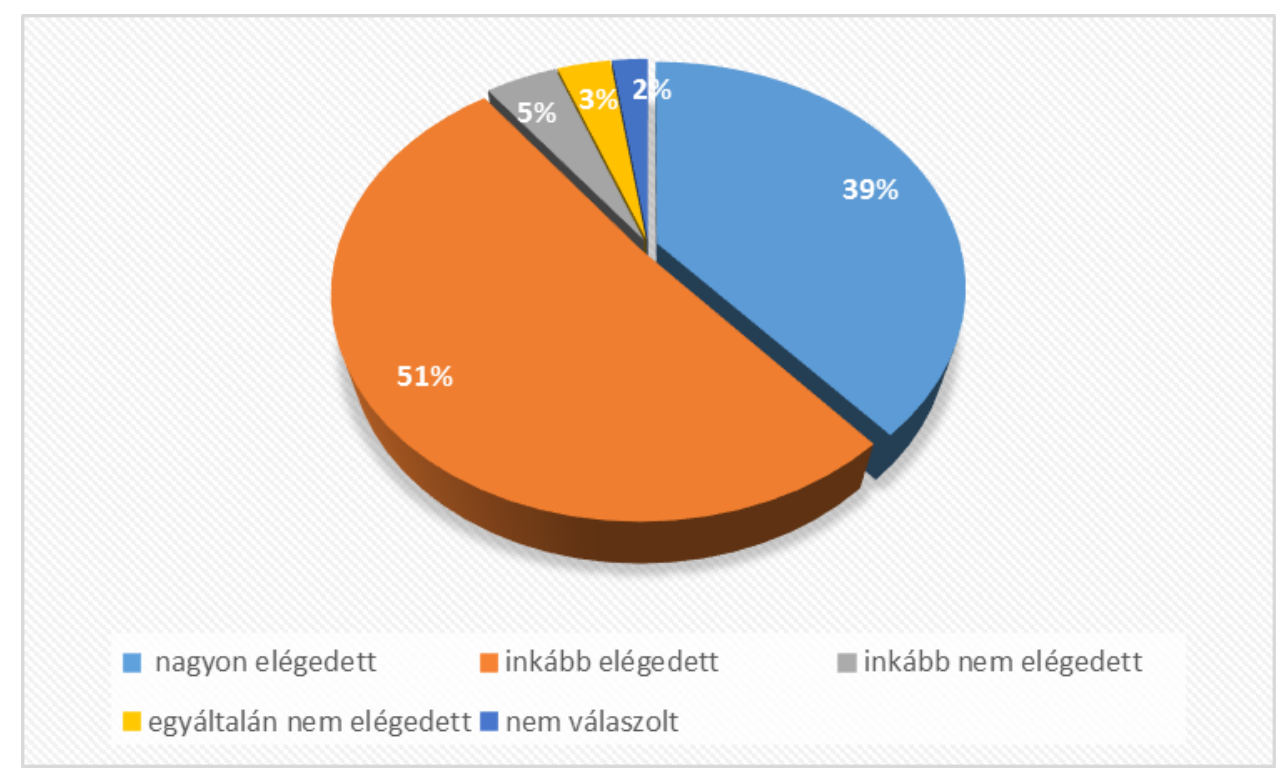

Az elégedettség és a jövedelmi helyzet $(\mathrm{p}=0,000)$ valamint a fiúk és lányok elégedettsége között szignifikáns összefüggést tapasztaltunk $(\mathrm{p}=0,000)$.

\section{1. táblázat. Élettel való elégedettség (\%). Forrás.Szerzök.}

\begin{tabular}{|l|r|r|}
\hline & Nö & \multicolumn{2}{|c|}{ Férfi } \\
\hline Nagyon meg vagyok elégedve & 44,4 & 34,4 \\
\hline Inkább elégedett vagyok & $\mathbf{4 8 , 1}$ & $\mathbf{5 9 , 4}$ \\
\hline Inkább nem vagyok elégedett & 3,7 & 3,1 \\
\hline Egyáltalán nem vagyok elégedett & 3,7 & 3,1 \\
\hline Nem tudom, nem válaszolok & 0,0 & 0,0 \\
\hline
\end{tabular}

Az 1. táblázatban látható, hogy bár mindként nemre jellemző az elégedettség, a legelégedettebb válaszlehetőséget nagyobb arányban választották a lányok, mint a fiúk. A fiúkra inkább egy óvatosabb válaszadói attitüd jellemző.

Személyiségjegyek 
A következő kérdések a személyiség, jellemvonások téma köré csoportosultak. Azonban mielött az eredményeket megosztanánk egy kis pszichológiai megjegyzést szeretnénk adni, miszerint egyes stabil személyiségvonások összekapcsolhatók az arousal rendszer müködésében fennálló egyéni tulajdonságokkal. Az arousal jelentése általános agyi aktivitási szint és rendszer, azaz a szervezet éberségi állapota (mipszi.hu). Ez az ismeret pedagógiai szempontból igen meghatározó lehet a tanulónak a feladat megoldásában illetve a kitüzött cél megvalósításában. A motiváció feltárására különböző tesztek állnak a rendelkezésünkre, mint például önjellemzési, személyiségvizsgáló tesztek, szorongás vizsgálatára alkalmas kérdőívek. Két csoportot szeretnénk kiemelni: a kudarckerülők és sikerorinetáltak csoportját, mellyel mérhető a teljesítménymotiváció. Azokat az egyéneket, akik közepes nehézségü feladatokat szívesen oldanak meg, kitartóak, sorozatos kudarcok nem törik le, akik nem adják fel a kitüzött célt, hanem inkább küzdenek érte, őket sikerorientáltaknak nevezzük. Ezzel ellentétben a kudarckerülő személyeknél a közepes nehézségü feladatoknál a legalacsonyabb a motiváció. A kudarcot saját képességeik hiányának tekintik, egy-egy sikerről nehezen hiszik el, hogy saját maguknak köszönhetik (Fodor, 2007).

Ehhez kapcsolódóan arra voltunk kiváncsiak, hogy a felsorakoztatott kijelentésekről hogyan gondolkodnak a diákok. (2.táblázat). Láthatjuk, hogy a válaszadók többsége a sikert a saját hozzáállásának tulajdonítja nem a feladat nehézségétől teszi függővé. Ez a fentebb leírtak alapján egyfajta sikerorientált attitüdöt takar. Ezt megerösíti az a tény, hogy mindössze heten gondolták azt, hogy a jó eredményhez szerencse kell. Az eredményekböl az is látható, hogy a válaszadók a tanulásra szánt időnek is kiemelkedő jelentőséget tulajdonítottak eredményeik alakulásában. Ehhez kapcsolódóan azt is megkérdeztük, hogy naponta mennyi időt fordítanak tanulásra. A válaszok igen széles skálán mozogtak, a legrövidebb 5-10 perctől egészen a napi 7 óráig terjedt az időintervallum. ${ }^{3}$

2. táblázat: Az alábbiak közül válaszd ki azt, amelyik a leginkább jellemzö Rád?.(forrás: Pálosi és R. Fedor 2017 saját vizsgálat)

\begin{tabular}{|l|r|}
\hline \multicolumn{1}{|c|}{ Állítások } & fó \\
\hline Ahhoz, hogy jó eredményt érjek el, rajtam múlik és nem a feladat nehézségén. & 55 \\
\hline Ahhoz, hogy jó eredményt érjek el ahhoz szerencse is kell. & 7 \\
\hline Ha nem szánok elég időt a tanulásra az a teljesítményemben is megmutatkozik & 16 \\
\hline Ha rosszul sikerül a dolgozatom/vizsgám, akkor magamat hibáztatom & 6 \\
\hline Nem válaszolt & 4 \\
\hline
\end{tabular}

Nemekre lebontva az otthoni tanulás időtartamát azt tapasztaltuk, hogy a fiúk saját bevallásuk szerint kevesebb tanulással is beérik, mint a lányok. $(\mathrm{p}=0,022)$ Előbbiek közül a legnépesebb csoport a maximális egyórát, utóbbiak a maximális 3 órát jelölték meg a legnagyobb arányban.

A következő kérdésünkben arra próbáltunk választ kapni, hogy a motivált állapotot milyen testi tünetek kísérik az érintett diákok esetében. A többség arról számolt be, hogy bár előfordul vele, hogy izgul dolgozatírás elött, de ezt az állapotot testi tünetek nem kísérik. Meglepő és elgondolkodtató, hogy második helyen szerepel a szorongás testi tünetekkel válaszlehetőség. 14 fő a magabiztosságot sejtető „,nem izgulok, nincs lámpalázam” kijelentéssel értett egyet. (3 táblázat)

\footnotetext{
${ }^{3}$ Részletes adatok feldolgozás alatt.
} 
3. táblázat: Gyakran szorongsz-e dolgozat elött? Vannak-e testi tüneteid (émelygés, hasmenés, hasfájás, fejfájás)? (forrás: Pálosi és R. Fedor 2017 saját vizsgálat)

\begin{tabular}{|l|r|}
\hline \multicolumn{1}{|c|}{ Állítások } & \multicolumn{1}{|c|}{ fó } \\
\hline Igen szorongok testi tünetekkel & 22 \\
\hline Szorongok, testi tünetek nélkül & 16 \\
\hline Nem izgulok, nincs lámpalázam & 14 \\
\hline Néha elöfordul, hogy izgulok ez testi tünetekkel is jár & 6 \\
\hline Néha előfordul, hogy izgulok, de testi tünetek nélkül & 26 \\
\hline Nem válaszolt & 4 \\
\hline
\end{tabular}

Valószinű ez köszönhető az iskola versenyszellemének is, mint az kiderül a korábbi értékekből, mely szerint igen magasan kvalifikált, átlag feletti tanulmányi eredménnyel rendelkező, jó képességü gyermekek kerülnek ebbe a gimnáziumba.

Válaszadóink vélemény nyilvánításából egyértelmüen kiderül, hogy a lányok dolgozatírás, felelés előtt szorongóbb attitűdöt mutatnak, mint a fiúk (4.táblázat). A Khi-négyzet próba lefuttatása szignifikáns kapcsolatot mutat $(\mathrm{p}=0,000)$ a szorongás és a nemhez való tartozás között. Ezen belül két szembetünő kijelentéshez kapcsolódó választ emelünk ki. Az egyik a legerösebb szorongást/félelmet takaró kategória: „Igen szorongok testi tünetekkel”, a másik ennek ellenkezője: „Nem izgulok, nincs lámpalázam”, a nyugodt, tét nélküli, lazább vélemény. Előbbi a lányok több mint egyharmadát érinti, míg a fiúknál ez az arány $10 \%$ alatt van. Utóbbi, a fiúkra jellemző inkább. Közel egyharmaduk nyilatkozott, úgy, hogy nem igazán szokott ilyen helyzetekben izgulni. A lányok 5,6\%-a válaszolt hasonlóan. Az okok magyarázatára nem térünk ki részletesen, de azt gondoljuk, hogy eredmények nem meglepőek. A lányok fokozott normakövetése, megfelelési vágya és az ennél lazább fiúk macho viselkedése érhetö talán tetten.

4. táblázat: Gyakran szorongsz-e dolgozat elött? Vannak-e testi tüneteid (émelygés, hasmenés, hasfájás, fejfájás)? (forrás: Pálosi és R. Fedor 2017 saját vizsgálat)

\begin{tabular}{|l|r|r|}
\hline & Nők & \multicolumn{1}{|c|}{ Férfiak } \\
\hline Igen szorongok testi tünetekkel & $\mathbf{3 5 , 2}$ & $\mathbf{9 , 4}$ \\
\hline Szorongok, testi tünetek nélkül & 20,4 & 15,6 \\
\hline Nem izgulok, nincs lámpalázam & $\mathbf{5 , 6}$ & $\mathbf{3 1 , 3}$ \\
\hline Néha elöfordul, hogy izgulok ez testi tünetekkel is jár & 5,6 & 12,4 \\
\hline Néha elöfordul, hogy izgulok, de testi tünetek nélkül & 31,5 & 31,3 \\
\hline Nem válaszolt & 1,9 & 0,0 \\
\hline
\end{tabular}

\section{Továbbtanulási szándékok, munkaerö-piaci elvárások}

Napjainkban a médiában gyakran hallani, hogy kevés a szakember, akik pedig valamilyen jó szakképzettséggel rendelkeznek elhagyják az országot a jobb megélhetés reményében. Ehhez kapcsolódóan megkérdeztük a fiatalokat arról, hogy tervezik-e, hogy az érettségi után tovább fognak tanulni, valamint, hogy tervezi-e, hogy tanulmányaikat külföldön folytatják majd?

A megkérdezettek körében a 88-ból 72 fó szeretné a tanulmányait folytatni valamelyik alapképzésben illetve felsőoktatási képzésben Azt, hogy hol található az intézmény, melyben tanulni szeretne, 39 fö válaszolta Debrecent, Budapestet 37 fö jelölte meg és külföldi tanulmányokban csupán 8 fő gondolkozik. Egy-egy fö Pécset és Kecskemétet jelölte meg. 
Azon belül is, hogy melyik területen szeretnének továbbtanulni elsőnként jelölték meg az egészségügyet, második a gazdasági tudományterület és harmadik helyen az informatika szerepelt. Ezek az adatok azt igazolják, hogy elsősorban az adott régióban valamint a fővárosban kívánnak továbbtanulni a fiatalok.

Azonban a következő kérdés adatai ellentmondásba kerültek az előzővel. Miszerint nyolc tanuló képzeli el azt, hogy külföldön szeretné folytatni a tanulmányait, de ezek mellett 45 hallgató válaszolt arra a kérdésre, hogy ha külföldön szeretne tanulni, akkor melyik országban képzeli el ezt. Az alábbi táblázatban láthatjuk, hogy számos ország neve felkerült a listára. Fej-fej mellett vezet Amerika és Anglia. 43 fő nem válaszolt. (5.táblázat).

5. táblázat: Ha külföldön szeretnél tanulni, melyik országban? (forrás: Pálosi és R. Fedor 2017 saját vizsgálat)

\begin{tabular}{|l|r|l|r|}
\hline \multicolumn{1}{|c|}{ Ország } & Fö & \multicolumn{1}{|c|}{ Ország } & Fö \\
\hline Amerika & 12 & Spanyolország & 1 \\
\hline Anglia & 12 & Ausztrália & 1 \\
\hline Németország & 10 & Japán & 1 \\
\hline Franciaország & 3 & Olaszország & 1 \\
\hline Dánia & 2 & Hollandia & 1 \\
\hline Ausztria & 1 & Nem válaszolt & 43 \\
\hline
\end{tabular}

A fent közölt adatok ellenvetése az alábbi kérdésben tisztázódni látszik, hogy miért szeretnének más országban tanulni a fiatalok. Több lehetséges válasz is adható volt. (6.táblázat) A külföldi tanulmányokkal a cél elsőként a magasabb életszínvonal elérése (46 fö). Ez alátámasztja a korábbi kutatások eredményeit. Az okok rangsorában második helyen a „,világot szeretnék látni” kategóri áll (40 fö) és ezt követi a tanulmányok befejezését követő könnyebb munkavállalási, karrierépítési lehetőség (28fó).

6. táblázat: Miért szeretnél külföldön tanulni? (forrás: Pálosi és R. Fedor 2017 saját vizsgálat)

\begin{tabular}{|l|r|}
\hline \multicolumn{1}{|c|}{ Állítások } & \multicolumn{1}{|c|}{ fó } \\
\hline Külföldi diploma megszerzése miatt & 13 \\
\hline Világot szeretnék látni & 40 \\
\hline A magasabb szintü, minőségü oktatás miatt & 25 \\
\hline A külföldi tanulmányok nagyobb lehetőséget adnak az áttelepülésre & 19 \\
\hline Jobban felszereltek a laboratóriumok, könyvtárak & 15 \\
\hline Magasabb az életszínvonal & 46 \\
\hline Demokrácia és szólásszabadság van & 6 \\
\hline Olyan felsőoktatási intézmény van, ami közel van a lakóhelyemhez & 0 \\
\hline A tanulmányok befejeztével könnyebb munkát vállalni, karriert építeni & 28 \\
\hline Könnyebb az önmegvalósítás, a képességeim fejlesztése & 13 \\
\hline Biztonságosabb, távol van a háborús konfliktusoktól & 2 \\
\hline Könnyebben lehetek független, önálló & 14 \\
\hline Mozgalmas az élet, lehetőség van érdekesen eltölteni a szabadidőt & 24 \\
\hline Nincs korrupció az oktatásban & 5 \\
\hline
\end{tabular}


A munakerö-piaci kitekintés kapcsán megkérdeztük a végzős fiatalokat, hogy hol szeretnének dolgozni a diploma megszerzése után (5. ábra). Vezető helyen szerepel a külföldi cég majd ezt a követi a saját üzleti vállalkozás. Érdekes, hogy a családi vállakozás, mint az egyik lehetséges munkahely az utolsó helyre került a ranglistán. Talán ez annak tudható be, hogy pszichológiailag ezt a korosztályt jellemzi az önállósodás, a függetlenség, leválás a családról, az ego kibontakozása és érvényesülése.

5. ábra. Hol szeretnél dolgozni a diploma megszerzése után?(fö) (forrás: Pálosi és R. Fedor 2017 saját vizsgálat)

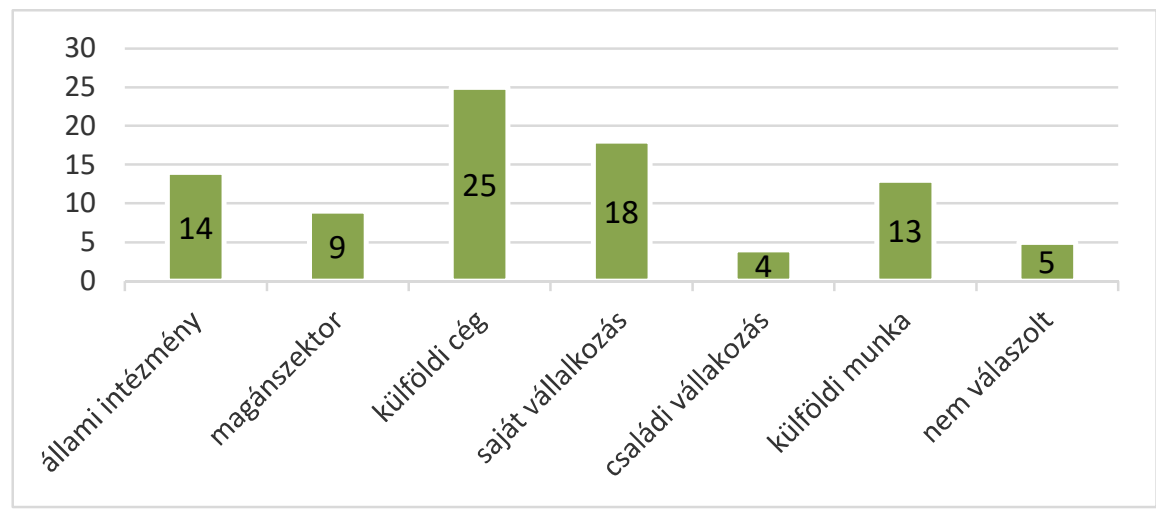

Arról, hogy milyen esélyeik vannak a jövőre vonatkozóan céljaik megvalósításában, igen optimistán vélekednek a diákok. Az erre vonatkozó adatokat a 7. táblázatban foglaltuk össze.

7. táblázat: Hogy gondolod, mennyire sikerül megvalósitani a jövőre vonatkozó terveidet?

(forrás: Pálosi és R. Fedor 2017 saját vizsgálat)

\begin{tabular}{|l|r|}
\hline \multicolumn{1}{|c|}{ Állítások } & fö \\
\hline Nagyon nagy eséllyel sikerül & 5 \\
\hline Nagy eséllyel sikerül & 58 \\
\hline Közepes eséllyel sikerül & 10 \\
\hline Kevés eséllyel sikerül & 1 \\
\hline Nagyon kevés eséllyel sikerül & 0 \\
\hline Nem válaszolt & 14 \\
\hline
\end{tabular}

A vizsgálatunk eredményeinek megértéséhez szükségesnek tartottuk, hogy a fiatalok társadalmi, szociokulturális jellemzőire is rákérdezzük. Ehhez kapcsolódóan érdemes kitekinteni a családi háttérre, mely nagy hatással bír a fiatalok életére. Értve ezalatt a fent említett témákat. Korábbi kutatások igazolták, hogy az „eltérő szociokulturális környzetből származó gyermekek készségeinek, képességeinek fejlettségében jelentős különbségek vannak".(Józsa, 2007:150). Fejes József és munkatársai a családi háttér tanulási motivációra gyakorolt hatását elemezték a tanulók önjellemzéseire alapozva (Józsa,2007:150). Láczay és R. Fedor (2017) összefüggést talált a szülőkkel való kapcsolat minősége és a különböző kockázati tényezők (alkohol, drog fogyasztás, dohányzás) jelenléte között.

Saját vizsgálatunkban a családi háttér meghatározó faktoraként a szülők iskolai végzettségét (1sd.12.táblázat) és beosztását tekintettük. (8. táblázat) 
8. táblázat: Szülők iskolai végzettsége (fö). (forrás: Pálosi és R. Fedor 2017 saját vizsgálat)

\begin{tabular}{|l|r|r|}
\hline \multicolumn{1}{|c|}{ Iskolai végzettség } & \multicolumn{1}{c|}{ Apa } & \multicolumn{1}{c|}{ Anya } \\
\hline Nem befejezett általános iskola & 0 & 0 \\
\hline Általános iskola & 0 & 1 \\
\hline Szakiskola/szakmunkásképzö & 6 & 1 \\
\hline Szakközépiskola & 4 & 4 \\
\hline Gimnázium & 6 & 7 \\
\hline Technikum & 6 & 3 \\
\hline Főiskola, alapképzés (Ba/Bsc) & 17 & 23 \\
\hline Egyetem,mesterképzés MAa/MSc) & 25 & 28 \\
\hline Tudományos (PhD./doktori & 20 & 18 \\
\hline Nem válszolt & 4 & 3 \\
\hline
\end{tabular}

A szülők iskolai végzettség és beosztás szerinti mintázata (9.táblázat) egy erőteljes magasan kvalifikált szülői háttérről árulkodik. A szülők több mint a fele, (apa 62 fö, anya 69 fö esetében) minimum föiskolai vagy annál magasabb végzettséggel rendelkezik.

9. táblázat: A szülők beosztása (fö).(forrás: Pálosi és R. Fedor 2017 saját vizsgálat)

\begin{tabular}{|c|c|c|}
\hline Beosztás & Apa & Anya \\
\hline Igazgató, cégvezetőségi tag, vezető, képviselő & 16 & 12 \\
\hline Felsőfokú végzettségü szakember (tanár, orvos, jogász, író) & 25 & 38 \\
\hline Mérnök, középszintü hivatalnok & 6 & 6 \\
\hline Alsóbb szintü hivatalnok (titkár, pénztáros) & 2 & 6 \\
\hline Cégtulajdonos & 11 & 5 \\
\hline Kereskedelmi vagy szolgáltatási dolgozó & 11 & 11 \\
\hline Szakmunkás & 6 & 1 \\
\hline Betanított, segédmunkás, mezőgazdasági munkavállaló & 1 & 2 \\
\hline Gazdálkodó (farmer, őstermelő) & 1 & \\
\hline Munkanélküli & & 1 \\
\hline Nyugdíjas & 1 & \\
\hline Egyéb (adja meg) & meghalt:2 & $\begin{array}{r}\text { óvónö, } \\
\text { pénzügyi } \\
\text { menedzser }\end{array}$ \\
\hline Nem válaszolt & 6 & 4 \\
\hline
\end{tabular}

A szülői példa, az otthoni minta követése igen meghatározó szerepet játszik a gyermekek életében. A kavlifikált, szakmai sikereket elérő szülők erős motiváló erőt jelenthetnek gyermekeik számára a tanulmányi életút eredményessége és a későbbi pályaválasztásra vonatkozóan is. Erre különösen ha azt felnőtt fejjel teszi meg az édasanya vagy édesapa. Az iskolai végzettségből következik a szülők beosztása, mely szintén döntő többségben (apa 41 fö, anya 50 fö) minimum tanár, orvos, jogász vagy valamilyen vezetői pozícióban dolgozik a szülők meghatározó része. Mind az iskolai végzettséget, mind a beosztást tekintve a házastársak között az anyák oldalára billen a mérleg.

A staisztikai próba szignifikáns kapcsolatot mutat a diákok teljesítménye az anya $(p=0,000), \quad$ az apa iskolai végzettségével $(p=0,000)$ és az anya beosztásával $(p=0,000) . A z$ 
apa beosztása nem meghatározó a teljesítmény szempontjából $(\mathrm{p}=0,099)$ a gimnáziumba járó fiatalok tekintetében.

Az iskolai végzettséget magyarázó változóként viszgálva azt látjuk, hogy az anya egyetemi végzettsége egyértleműen kitünő teljesítményt valószinűsít a tanulóknál. A kitünő eredményt elérő gyerekek 40\%-nak egyetemet végzett az édesanyja. Második helyen a tudományos fokozattal bíró anyák gyerekei vannak $28 \%$. Hasonló összefüggést és arányokat találtunk az apák vonatkozásában is.

Az anya beosztását vizsgálva azt látjuk, hogy a „felsőfokú szakember „, kategóriájába tartozó anyák gyermekei teljesítenek a legjobban (48\%), de ami érdekes, a közepes tanulmányi eredménnyel bíró gyerekek többsége is ilyen beosztású anyával bír. Utóbbi esetben meg említem, hogy az egy cellára jutó elemszám igen kicsi. A megosztott második hely a beosztási hierarchi csúcsán lévő ,igazgatói, cégvezetőségi,, pozícióban valamint a középmezőnyben elhelyezkedő „kereskedelmi és szolgáltatási területen dolgozó” anyák gyermekei állnak 20-20\%-uk bír kitünő eredménnyel. Öket követik a közép és alsó szintü hivatalnokok gyermekei 4-4\%-kal, és az egyéb kategória szintén 4\%-kal.

A család jövedelmi helyzete és a tanulmányi eredmény közötti összefüggést nem bizonyítják az adataink, a válszadó debreceni diákok tanulmányi eredménye nem függ a család anyagi helyzetétöl $(\mathrm{p}=0,653)$.

\section{Konklúziók}

Írásunkban a fiatalok tanulási motivációit, munkaerő-piaci elvárásait vizsgáltuk egy debreceni gimnázium végzés előtt álló hallgatói körében. A 88 fő diák véleménynyilvánításából egy igen magas tanulmányi eredménnyel és magasan kvalifikált szülői háttérrel bíró diákcsoport rajzolódott ki előttünk. Kutatásunk eredményeinek jelentős része ezekkel a jellemzőkkel szorosan összefügg. Ugyanezen jellemzők jelentik eredményeink korlátait is. E szerint vizsgálatunk jelenlegi megállapításai nem terjeszthetők ki a végzős fiatalok csoportjára általában. Ennek a kritériumnak akkor felelnek meg majd az adataink, ha az általunk tervezett további iskolánk diákjait is megkérdezzük az érintett témában.

Vizsgálatunk alapján az alábbi következtetéseket vonjuk le: a fiatalok tanulásának elsődleges mozgatórugója a sikerek elérése, a jó érdemjegy megszerzése mellett a jó teljesítménnyel kapcsolatos kötelességtudat. Ehhez kapcsolódóan a fiatalok egy része szorong és testi tüneteket is produkál dolgozatírás elött, mely vélhetően összefügg azzal, hogy az elért eredménynek tétje van. A megmérettetés előtti szorongás inkább a lányokra volt jellemző.

Motiváló tényezőként a tárgyi dolgok háttérbe kerülnek és a belső indítatás, a siker és az élettel való elégedettség kerül előtérbe.

A családi faktorok közül a szülők iskolai végzettségét tekintve elmodhatjuk, hogy az édesanyák egyetemi végzettsége egyértlemüen kitűnő teljesítményt valószinűsít. Mindemellett statisztikailag meghatározó kapcsoolatot találtunk az apa iskolai végzettsége, az anya beosztása és a diák teljesítménye között.

A külföldi karrier elsősorban a jobb megélhetés és a világ megismerése miatt népszerü.

A fiatalok általában elégedettek az életükkel és úgy vélik, hogy nagy eséllyel sikerül megvalósítaniuk a jövőre vonatkozó terveiket.

Rövid távú céljaink között szerepel, hogy elemző munkánkat kiterjesztjük s eredményeinket összehasonlítjuk a fentebb bemutatott általános gimnáziumba járó és a jelenleg feldolgozás alatt lévő szakgimnáziumban tanuló diákok válaszaiból nyert eredményekkel, melyből némi ízelítőt jelenlegi írásunkban is adtunk. További tervünk, hogy eredményeinket összevetjük a Youth in Central and Eastern European Cross-border Areas kutatásban résztvevő nyíregyházi 
fiatalok jellemzőivel. Az előzetes összehasonlító kitekintésünk jelentős különbségek jelenlétét sejtetik e három alminta tekintetében.

\section{IRODALOM}

Coleman, J. S. (1996): A társadalmi tőke. In: Lengyel György - Szántó Zoltán (szerk). A gazdasági élet szociológiája. BKE Szociológiai és Szociálpolitikai Tanszék, Budapest, 99129.

Engler, Á., R. Fedor, A.,_Markos, V. (2016): Vision and plans of the young peole os Nyíregyháza about thetir futre.Youth in central and Eastern Europe. Sociologocal studies (2) pp. 118-135.

Fodor, L.ó (2007) Fejezetek a motivációkutatásból Gondolat Kiadó Bp.

Józsa, K. (2007) Az elsajátítási motiváció Műszaki Kiadó

Kovács, K., Dusa, Á., Ludescher. G.,(2016): Globalization, Localization and Individualization among High School Students in Nyíregyháza. Youth in central and Eastern Europe. Sociologocal studies 5:(2) pp. 98-117. (2016

Láczay, M., R. Fedor, A. (2017):_A szabolcs-szatmár-beregi fiatalok bizalmi kapcsolatainak bemutatása kockázati tényezők elemzése alapján: prediktorok és protektorok egy vizsgálat adatbázisának több dimenziós elemzésében. In: Fábián Gergely, Szoboszlai Katalin, Hüse Lajos (szerk.) A társadalmi periférián élö gyermekek és fiatalok rizikómagatartásának háttere.

Nyíregyháza: Periféria Egyesület, 2017. pp. 73-90.

Réthy Endréné (2003): Motiváció, Tanulás, Tanítás Miért tanulunk jól vagy rosszul Nemzeti Tankönyvkiadó Bp. 


\section{MÓDSZERTANI TANULMÁNYOK}




\title{
DISZLEXIÁVAL NÉMETÜL
}

Szerzők:

Mályusz Enikő

Debreceni Egyetem Kossuth Lajos

Gyakorló Gimnáziuma és Általános Iskolája

Mező Katalin

Debreceni Egyetem

Első szerző e-mail címe:

nonnaeni@hotmail.com
Lektorok:

\author{
Szalay Kristóf \\ német nyelvtanár \\ Mozgásjavító Általános Iskola \\ Egri Tímea \\ ELTE Bárczi Gusztáv \\ Gyógypedagógiai Kara \\ Varga Imre \\ Szegedi Tudományegyetem \\ Nemes Magdolna \\ Debreceni Egyetem
}

Mályusz Enikő, Mező Katalin (2017): Diszlexiával németül. Különleges Bánásmód, III. évf. 2017/4. szám, 67-75. DOI 10.18458/KB.2017.4.67

\begin{abstract}
Absztrakt
Jelen tanulmány a diszlexiával küzdő tanulók német nyelvtanulásának sajátosságaihoz nyújt újabb információkat a tanulók nyelvi lexikális hálózatának felmérése által. A tanulmányban többek között arra kerestük a választ, hogy milyen jellemző jegyei jelennek meg a diszlexiának az idegen nyelvtanulásban? Valóban minden diszlexiás gyermeket fel kell menteni az idegen nyelvtanulása alól, vagy léteznek olyan utak, melyek elvezethetnek a nyelvtudás kialakulásához? Célunk a magyar anyanyelvü németül tanuló diszlexiások nyelvi tudásának mérése általi tanítási tapasztalatok levonása. Módszer: diszlexiások lexikális hálózatának felmérése szóasszociációs feladattal. Minta: 19 tanulási zavarral küzdő tanulót vizsgáltunk. Következtetés: Vizsgálati eredményeink azt bizonyítják, nem felmenteni kellene a diszlexiával küzdő gyermekeket, hanem az erősségeikre támaszkodva, más úton kellene átadni a tudást.
\end{abstract}

Kulcsszavak: diszlexia, idegen nyelv, fejlesztés, fejlesztőpedagógia

Diszciplina: pedagógia

\begin{abstract}
The current study provides insight into the specificities of dyslexic pupils learning German as a foreign language by measuring their language lexical knowledge. The aim was to explore the nature of dyslexia whilst learning a foreign language. Should we really free all such pupils from the strains of learning a foreign language? Or is it a case of finding the appropriate
\end{abstract}


methodology to learn a new language? The goal is to measure language skills in a foreign language and draw inferences from this. Method: Word association exercises are used to measure the lexical knowledge of children with learning disorders, including dyslexia. Sample: 19 students with learning disorders. Conclusion: The results clearly indicate that we should find pupils' individual strengths and utilise these, instead of simply exempting pupils from learning foreign languages.

Keywords: dyslexia, foreign language, development, developmental psychology

Disciplines: pedagogy

A diszlexia meghatározásának számos formája létezik. A korai kutatók közül Ranschburg (1916, idézi Meixner, 2012. 3.) a következőkkel alapozza meg a definíciót: ,a legasthenia a szellemi szervezetnek az a csökkentértéküsége, melynek következtében a gyermekek normális érzékszervek ellenére sem tudják az első években elsajátítani az olvasást." Később Luchsinger és Arnold (1970) ezt a jellemzést kiegészítette azzal, hogy ,átlagosan intelligens gyermekek veleszületett vagy a korai gyermekkorban szerzett képtelensége arra, hogy az olvasást és írást a szokott módon elsajátítsák." Bryant és Brandley (1985) meghatározásában a diszlexia a részképesség zavarok egyik változata, az írás és az olvasás elsajátításának neurológiai eredetü nehézsége, mely nem magyarázható értelmi fogyatékossággal vagy a megfelelő oktatás hiányáva. Napjaink diszlexia szemlélete annyiban változott, hogy a diszlexiát egyre inkább viszonyfogalomként értelmezik (Meixner, 2012, 3.), s azt tartják, hogy az olvasászavar esetében diszharmónia jelenik meg a gyermekkel szembeni jogos elvárások (pl. a gyerek adottságai); az olvasás-írás tanítására szánt idő és gyakorlási mennyiség; valamint az eredmény között. A legújabb diszlexia meghatározásokban (Christiansen, 2014, Csépe, 2014.) a diszlexiát neurológiai alapon közelítik meg, s a diszlexiát, mint „biogenetikus írási-olvasási nehézségnek" nevezik. Az agy bal frontális lebenyében bizonyos neuronok vele születetten megváltoznak, amelynek következtében egyes részképesség-területeken nem az életkornak megfelelö fejlödés tapasztalható. A nehézségek az olvasás, az írás területén, vagy mindkét területen jelentkezhetnek.

A diszlexia jellemzö tünetei a betütévesztések, betücserék az olvasásban; az olvasási tempó és a szövegértés zavara; az auditív és vizuális információ feldolgozás zavara; a gyenge rövidtávú memória; a sorrendiség, az irányok, a téri orientáció problematikája; a nyelvtani fogalmak megértésének nehézsége stb. (Tánczos, 2007). A diszlexiás tanulóknál mindezek komoly nyelvtanulási nehézséget idézhetnek elő, hiszen nem csak az írás és az olvasás nehezített, de a beszéd és a hallás utáni szövegértés is problémás. Mindezek figyelembe vételével a diszlexiás tanulók számára már 1993 óta (1993. évi LXXIX törvény a közoktatásról 30.§) számos kedvezmény áll rendelkezésre a nyelvtanulás megkönnyítéséhez pl. a teljes felmentés az értékelés alól; az írásbeli teljesítmény értékelése alóli felmentés; a helyesírás értékelése alóli felmentés; többletidő adásának lehetősége.

E törvényt félreértelmezve sokan a kedvezményeket a nyelvtanulás alóli teljes felmentésnek tekintik, s lehetőséget sem adnak arra, hogy a diszlexiás tanulók is örömmel vegyenek részt az idegen nyelvek elsajátításában. Holott a diszlexiások esetében is létezik eredményes idegen nyelvtanulás, bár mindez nagyban függ a nyelvtanítás módjától, a nyelvtanár hozzáállásától és a gyermek motivációjától is.

Jelen tanulmányban a diszlexiával küzdő tanulók idegen nyelvi lexikális hálózatának felmérése által szeretnénk képet kapni a német nyelv taníthatósági struktúrájáról. Tanulmányunkban a kialakulóban lévő lexikon vizsgálata kapott figyelmet, s ennek okán általános iskolás tanulók vizsgálatára került sor. Hagyományos körülmények között a kezdö 
nyelvtanulók szókincse jellemzően fonológiai, azaz hangzásbeli asszociációs alapon szerveződik, mivel a kialakuló szókincskészlet kapcsolatai még nem stabilak (Meara, 1983; Wolter, 2001; Zhang, 2003). Mindemellett az általános iskolások idegen nyelvi lexikájának szerveződésében a föneveknek van döntö szerepe. Kíváncsiak voltunk arra, hogy a diszlexiások szókincsbővítése során is a fonológiai szerveződésére kell építenünk, vagy az adott szó idegen nyelven való felidézését más módszerek alkalmazásával segíthetjük elő? Valljuk, hogy nem felmenteni kell a diszlexiás tanulót a nyelv tanulása alól, hanem a megfelelő utat kell megkeresni a tudás átadására, ehhez keressük a kapaszkodókat jelen tanulmányunkban.

\section{Kutatási minta}

A vizsgálatban 19 fő diszlexiás tanulási zavarral élö tanuló vett részt. A felmérés idején 9-14 évesek; 2 fö ötödik osztályos; 2 fő hatodik osztályos; 4 fő hetedik osztályos; 1 fő nyolcadik osztályos. A tanulók heti kettő, három illetve négy órában tanulnak németül. A minta létszáma alacsony $(\mathrm{N}=19)$, mivel a csoport speciális összetétele miatt- valamennyi tanuló diszlexiával küzd és idegen nyelvet tanul - a mintavétel nehezített. A diszlexiások kis létszámú osztályban tanulják az idegen nyelvet. Ebből következően a kutatásunkban megfogalmazottakat további kutatásokra érdemes tapasztalatoknak tekintjük.

\section{A kutatás módszere}

Kutatásunkban a magyar anyanyelvű németet, mint első idegen nyelvet; illetve az angol mellett, mint második idegen nyelvet tanuló általános iskolások nyelvi tudásának felmérésére került sor több szempontból. A vizsgálat során szóasszociációs teszt (Kohlmann, 2014) kitöltésére, valamint nyelvtanulási problémákat elemző egyéni válaszadásokra került sor. A szóasszociációs teszt négy feladatot tartalmazott: 1) az alapszókincshez tartozó szóasszociációs feladat (ennek bővebb kifejtése jelen tanulmányunk alapja); 2) 12 szó magyarra fordítása; 3) 10-13 szóhoz négy lehetséges válaszból a megfelelő szinonima kiválasztása; 4) tizennégy mondatban a kezdő betű és annyi pont megadásával, ahány betűből áll a szó, maga a szó pótlása.

A feladatok közül az első (az alapszókincshez tartozó szóasszociációs) feladat - melynek célja a tanulók lexikális tudásának, lexikális hálózatának felmérése - a következőképp valósult meg: 8 illetve 12 szóhoz kellett legalább három, legfeljebb öt válaszszót írni. A feladatválasztás célja, hogy minél spontánabb módon válaszoljanak a tanult nyelv valamelyikével a hívó szóra. Arra voltunk kíváncsiak, hogy hány választ vált ki egy-egy mérhető szó, milyen kategóriákba/szófajokba sorolhatóak a válaszszavak, illetve, hogy milyen nyelven adták meg azokat. Emellett az is megfigyelhető, hogy milyen területekröl aktiválják a válaszokat, milyen sorrendben, ezáltal az aktiváció terjedésének útvonala is nyomon érhető. A 8 illetve 12 német nyelvü hívó szó az iskolákban általánosan használt német tankönyvek alapján kerültek összeállításra. A hívószavak kiválasztásánál arra törekedtünk, hogy minél több témához kapcsolódjanak a megadott hívó szavak, növelve ezzel a válaszadás esélyét.

3. évfolyamon a szóasszociációs feladatba 5 fönév $(Z a h l=$ szám, Familie $=$ család, Schule $=$ iskola, Katze $=$ cica, Farbe $=$ szín), 2 ige $($ spielen $=$ játszani, lernen $=$ tanulni) és 1 melléknév (super $=$ nagyszerü $)$ került.

4. évfolyamtól kezdve a 12 szóból 7 főnév $(Z a h l=$ szám, Auge $=$ szem, Familie $=$ család, Schule $=$ iskola, Apfel $=$ alma, Hund $=$ kutya, Farbe $=$ szín $), 4$ ige $($ spielen $=$ játszani, lernen $=$ tanulni, essen $=$ enni, telefonieren $=$ telefonálni $)$ és 1 melléknév (gut = jó) szerepelt a tesztben.

A mért főnevek közül jelen tanulmányban a Familie, Schule fönevek; az igék közül a spielen és lernen szavak kerültek kiértékelésre, mert egyrészt ezek a szavak a 
legáltalánosabban használtak, másrészt ezekre a szavakra érkezett a legtöbb asszociáció a tanulóktól.

A feladat instrukciója a következő volt: „Kérlek, sorolj fel legalább három, legfeljebb öt szót, amelyek az alábbi szavakról bármely nyelven elöször eszedbe jutnak!"

A hívószavak után egy táblázatban öt hely állt rendelkezésre a szóasszociációk számára. A válaszokat bármely tanult nyelven (beleértve az anyanyelvüket is) adhatták meg, mert a vizsgálat célja a szókincsszerkezet feltérképezése volt spontán szófelidézési folyamattal.

A teszt kitöltése a tanítási órákon történt. A válaszadás irányítás/beavatkozás nélkül, spontán valósult meg, melynek eredményeként a tanulók kevés szót javítottak, az első eszükbe jutó gondolatot írták le. A teszt kitöltése 45 percet vett igénybe.

\section{Eredmények bemutatása a kiválasztott két főnév és két ige segítségével}

Az alábbi ábrákon a Familie, Schule fönevek, valamint a spielen és lernen igékre adott asszociációk kerülnek elemzésre. Minden ábrán láthatóak a válaszok számai egy-egy tanulási évre lebontva (azaz, hogy egy, két, három, négy, öt év német nyelv tanulása után hány asszociáció jutott eszükbe a tesztfelvétel idején); valamint megjelenítésre kerülnek az adott szóra adott asszociáció szófajai is (azaz az asszociáció szófaja: ige, főnév, melléknév vagy egyéb).

Az 1. ábrán a Familie főnév szó asszociációi jelennek meg: a diszlexiás tanulók esetében többnyire egyszerü fordítás jelenik meg asszociáció helyett (azaz Familie $=$ család). Csak a két éve nyelvet tanuló csoportban jelent meg ige szófajú asszociáció.

1. ábra. a Familie szó asszociációi. Forrás: Szerzők.

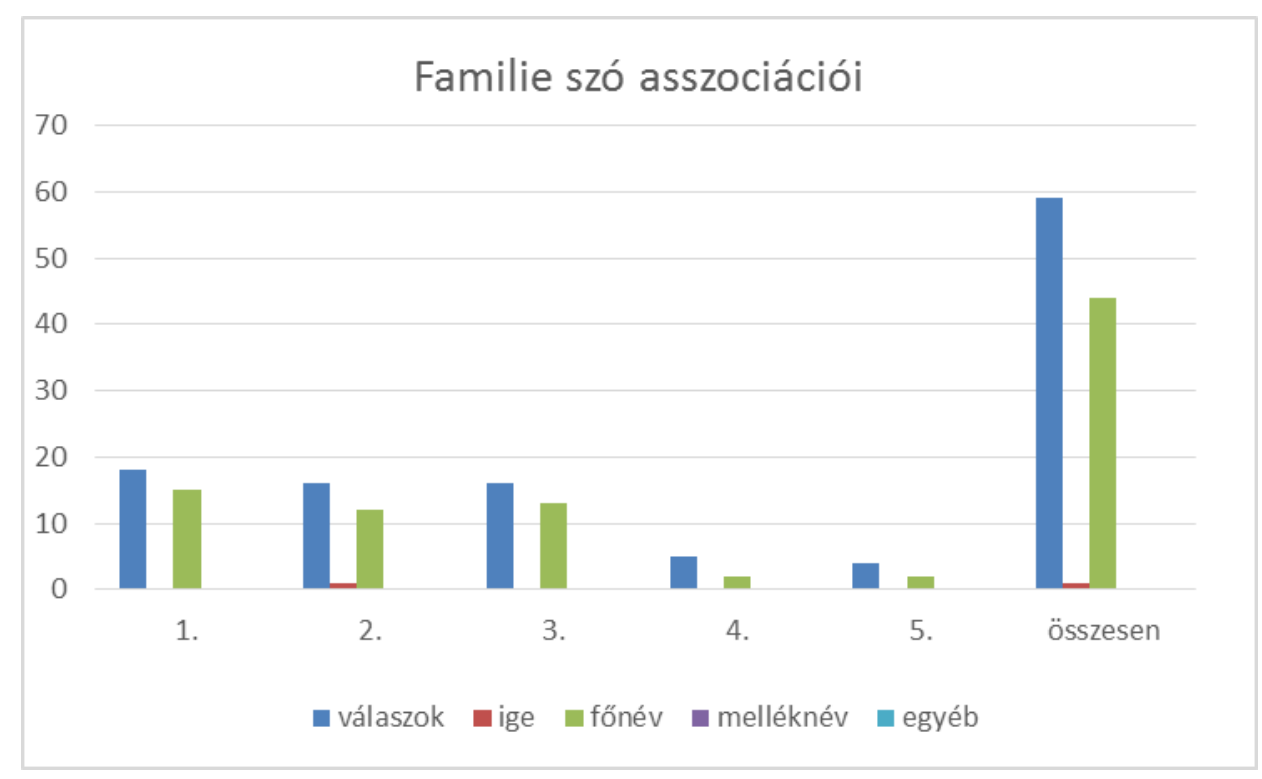

$\mathrm{Az}$ ige használata esetében az otthoni tevékenységet meghatározó szavakat írtak. Az egyszerü fordításon túl időnként a családtagjainak felsorolása is megjelent, ami viszont szintén fönév szófajú.

A Schule - iskola szó (2. ábra) esetében már nagyobb a szórási arány a szófajok tekintetében. Ennél a szónál a téma játszik elsődleges szerepet, a fordítási ekvivalens csak 
második helyen jelentkezik. Megjelentek már az igék és melléknevek is, ami a szó asszociatív fantáziára építő erejét erősítheti.

2. $\quad$ ábra. a Schule szó asszociációi. Forrás: Szerzök.

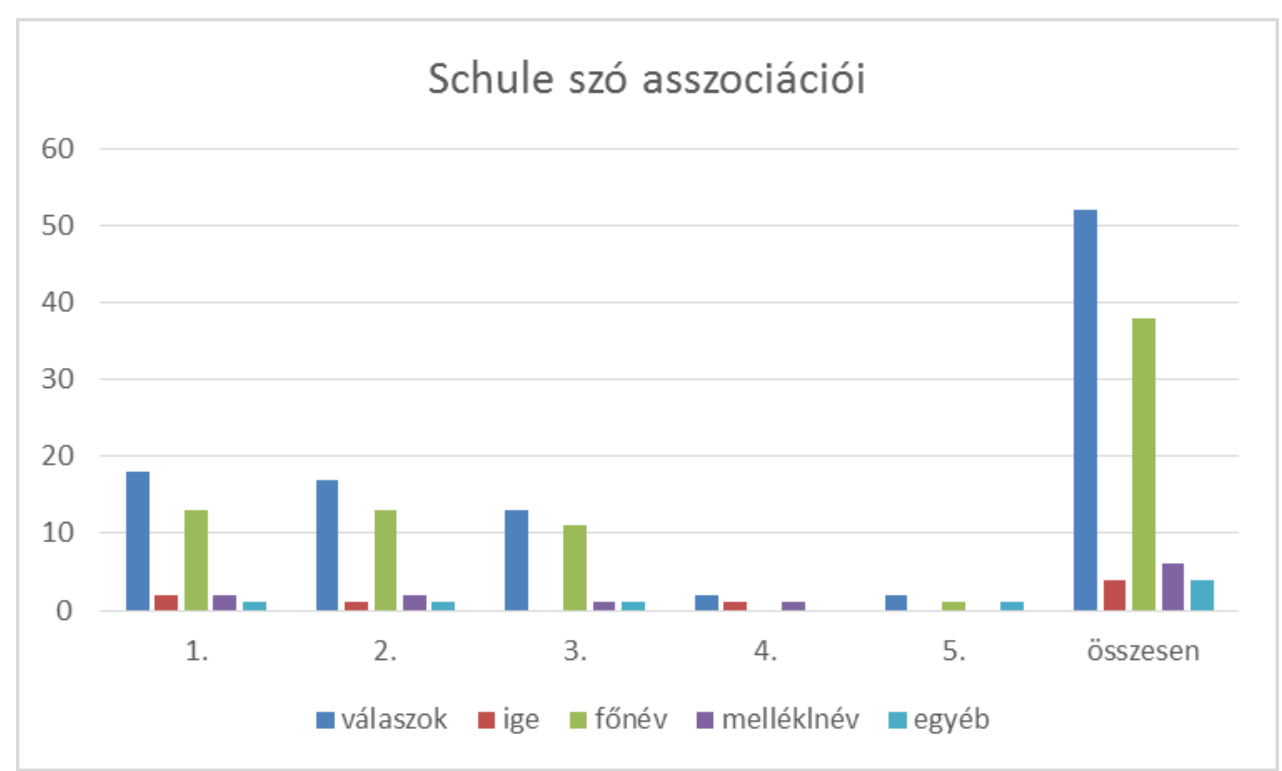

A lernen - tanulni ige (3. ábra) esetében a szóhoz tartozó augmentum lehetőségével éltek leggyakrabban a gyermekek. Felsorolták mi mindent lehet megtanulni (verset, mondókát, párbeszédet, szavakat, kifejezéseket, tantárgyakat), persze néhányan az unalom, nehéz, nem jó szavakkal asszociáltak.

3. ábra. a lernen szó asszociációi. Forrás: Szerzök.

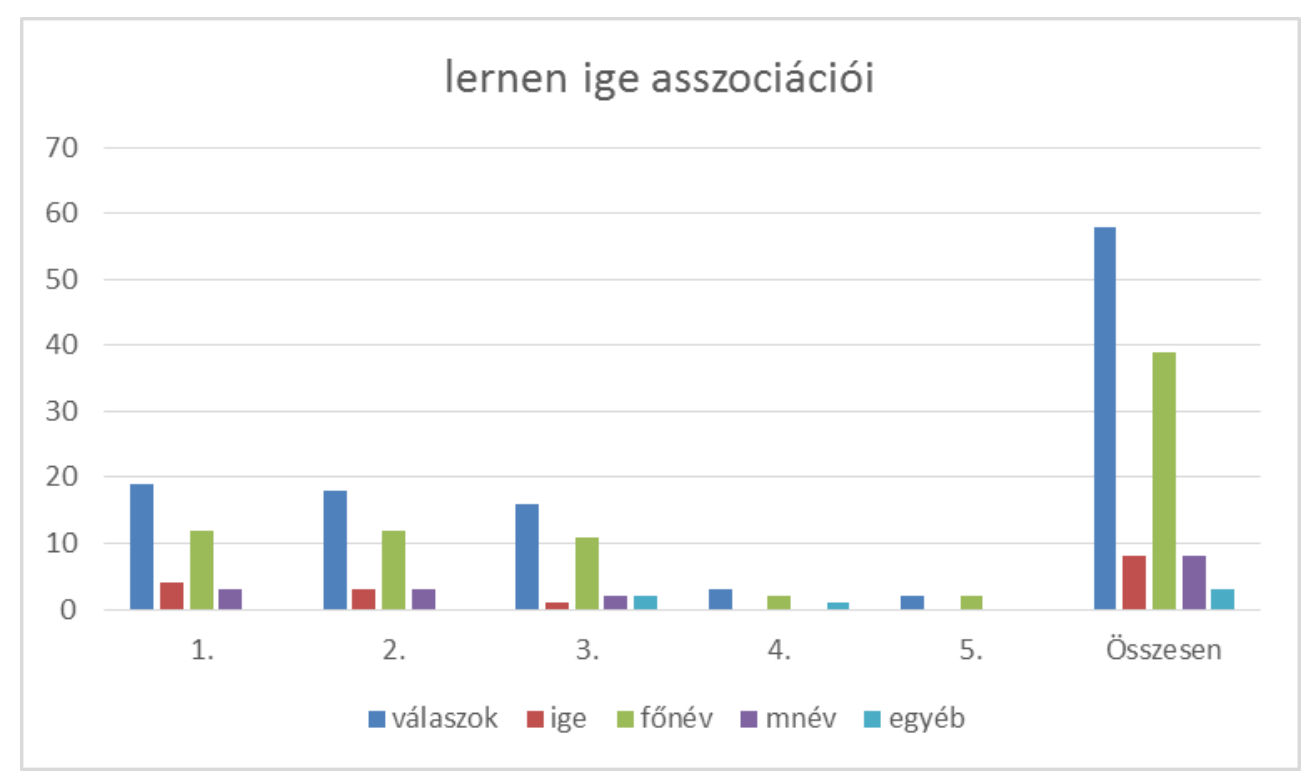

A spielen - játszani ige (4. ábra) esetében egyenlő arányban szerepel a fordítási ekvivalens a téma augmentumával. Nagyon sok labdajátékot (Fußball, Basketball, Volleyball) említenek a tanulók, talán a tankönyvi tananyag miatt. Vagy azért, mert ezekkel szeretnének játszani. 
Melléknevek is megjelennek a jó, nagyszerü szavak kíséretében. Főnevek közül a labdajátékok mellett a szórakozás szinonimái jelennek meg.

4. ábra. a spilen szó asszociációi. Forrás: Szerzök.

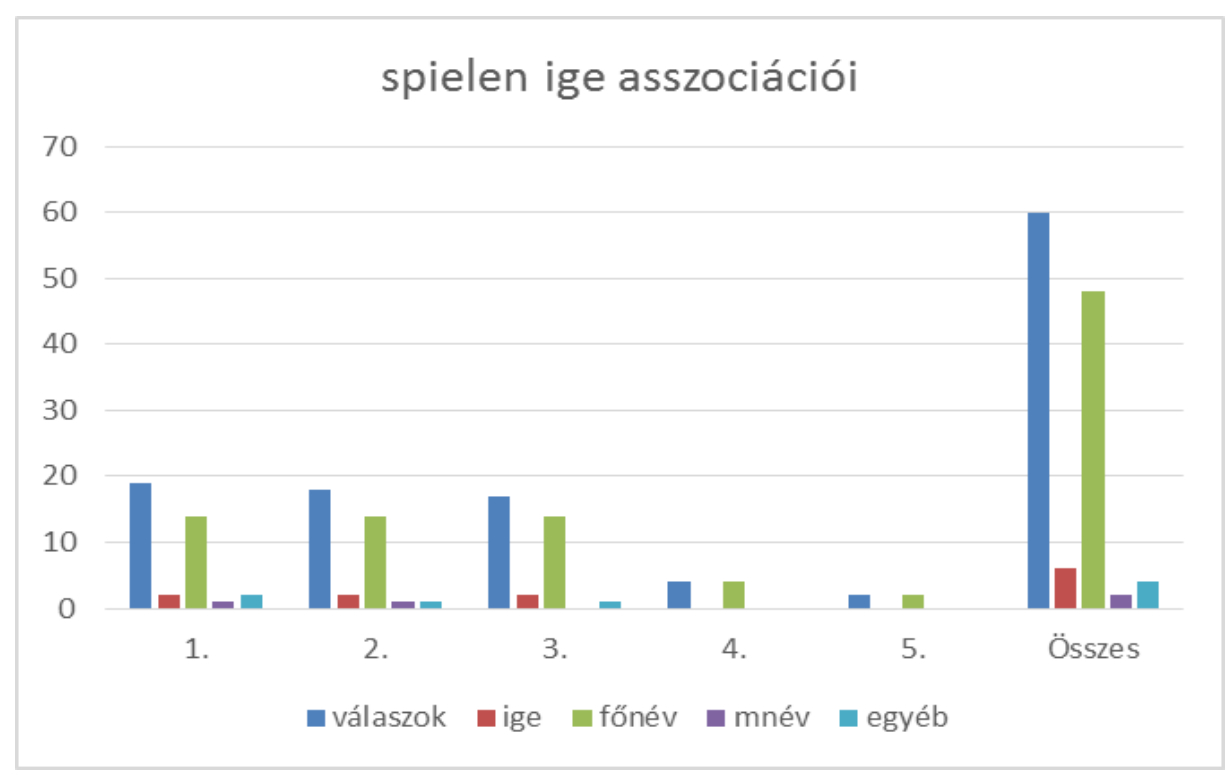

A teszt további feladataiban egy-egy szó fordítására került sor, majd a passzív szókincs teszteltelésére a szinonimák keresésével került sor. Végül az aktív szókincsvizsgálat következett mondatokban történő szópótlás segítségével.

\section{A nyelvtanulási problémákat elemző egyéni válaszadások eredményei}

A tanulók az egyéni válaszadásaiból az alábbi problémaleltárat lehet összeállítani:

1. Az angol nyelv tanulását a diszlexiás tanulók könnyebbnek érzik a német nyelvnél, melynek okait hasonlóan fogalmazták meg, mint a nem diszlexiások:

- „Az angol nyelvet könnyebben meg tudom tanulni, mert könnyebb a nyelvezete."

- „A németet a kiejtés és a névelök miatt nehezebben tudom megtanulni."

- „Az angol könnyebben megy; egyszerübb kiejteni a szavakat, a nyelvtana is egyszerübb. Könnyebb a névelők használata."

- „Nagyon sokban különbözik a két nyelv: eleve az angol egy egyszerübb nyelv. Míg a németben más mindennek a szabálya. Ragozásban is tele van kivétellel, plusz a der, die, das."

- „A mondatok felépítése a szavak kiejtése is nehéz, az angolban kevés az olyan szabály, amelyben kivétel van."

- „A szavak tanulása unalmas”

2. Több segítséget, kapaszkodót várnának a német nyelvtanulás segítéséhez:

- „Segít az, hogy órán a szótárfüzetbe a der-t kékkel a die-t pirossal és a das-t zölddel jelöljük. Ez sokat segít."

- „Segít az, hogy órán színekkel jelöljük a névelöket.”

- „Segítenek, ha a szavakat mozgással kísérjük.”

- „Jók a játékok” 


\section{Megvitatás}

A szóasszociációs teszt eredményeinek elemzése mennyiségi és minőségi szempont alapján történt. Mennyiségi szempontból vizsgáltuk, hogy, milyen arányban és hányan aktiváltak igét, konkrét fönevet, elvont fogalmat vagy melléknevet, valamint hányan éltek a lehetséges öt spontán válaszadás valamelyikével. Mennyiségi szempontból vizsgálva az asszociációs feladatot, megállapítható, hogy a diszlexiás tanulók csak a minimumra törekedtek. A legalább három szót beírták, legfeljebb ötöt már nem. Ez akár a szókincsük mennyiségi hiányára is utalhat

Minőségi szempontból azt elemzetük, hogy hányan éltek az asszociáció során első helyen fordítással, mivel a hazai tanulmányok (Dóczi, 2006). azt bizonyítják, hogy a fordítási ekvivalensek az alacsonyabb idegennyelvtudás-szinthez kapcsolódnak. Saját tapasztalataink is azt bizonyítják, hogy diszlexiások erős kapcsolatokat építenek ki a szavak és magyar jelentésük között a szótanulás megkönnyítésére. Ennek ismerete azért fontos, mert ez a tanulási stratégiák kiépítése során segítséget jelenthet pl. a memóriamankók, mnemotechnikák megalapozása során. A kezdő szinten álló diszlexiás nyelvtanulók több fordítási ekvivalenst aktiválnak, azonban mind a lernen, mind a spielen igének van téma augmentuma, a csoport ezt aktiválta a leggyakrabban. Mindkét igénél a fölérendelő összefoglaló kifejezések a második legerősebb kategória. Harmadik helyen a fordítási ekvivalens áll. Gyakran a konkrét tartalmakhoz kötődő eszközöket, funkciókat aktivizáltak a tanulók.

A tanulók többsége konkrét fordítást adott a szóasszociációs teszt során. Majd a következő oszlopokban a dologra jellemző tulajdonságot írta le. Egy tanuló talán félreértette az asszociáció szó fogalmát, s azonos mássalhangzókkal kezdődő szavakat írt a feladat minden sorába. Mivel szabad használat volt a tanult nyelveket illetően, így sokan csak magyar szavakat írtak be. A vizsgált csoportban megfigyelhető volt, hogy a diszlexiára utaló jegyek a német szavak esetében is megjelentek például vizuális hasonlóság miatt az azonos alakú vagy hasonló betükből álló szavak jelentését keverték (Mädchen - Mäppchen, Kreide - Kinder, Schwester - schwarz, Geschwister - Schwester stb.). Gyakran a magyar hang-betü kombinációját használják írás közben: például Vater ejtsd Fater. A kiejtés szerinti írás nagyon jellemző a diszlexiás tanulókra. Valamint az is jellemző, hogy arányaiban több magyar válasz adtak, mint német nyelvüt.

A német nyelvben a magyar nyelvhez hasonlóan magasabb a graféma-fonéma megfelelés aránya, mint például az angol nyelvben, a németül tanuló diszlexiás diákok a szavakhoz, fogalmakhoz kötődő sokrétü információt nehezebben aktiválják, erősebben kötődnek a lexikális kifejezésekhez, azaz a fogalmi feldolgozásuk alacsonyabb szinten történik.

A hangzásbeli asszociáció csak két diszlexiás tanuló esetében volt domináns, a többiek esetében a szituatív eszközkategória használata volt jellemző. Ebből az is következik, hogy az auditív, hangoztató tanítási módszerek egyedüli használata a diszlexiás tanulók esetében nem feltétlenül eredményes.

A vizsgálati eredmények azt is elővetítik, hogy sokkal több játékosságot, kreativitást igénylő feladatok alkalmazásával kell oktatni a tanulási zavarral küzdő tanulókat. A diszlexiás tanulók rövidtávú és munkamemóriája gyengébb, ez pedig megnehezíti a szótanulásukat. Mondhatnánk azt is (ahogyan ők is megfogalmazták), kifejezetten szenvedés és unalmas számukra a szótanulás. A befektetett energia nem hozza meg a várt eredményt. Gyakran nem emlékeznek a megtanult szavakra, vagy más szavakkal összekeverik azokat, esetleg félreolvasott szavakat jegyeznek meg. Mindezek ellenére a diszlexiás tanulók idegen nyelv tanulása eredményessé tehető, csak speciális tanítási/ tanulási eljárások alkalmazásával kell 
törekedni az optimális tanulási állapot elérésére. Nézzünk erre vonatkozóan néhány a német nyelv tanítása során is eredményes módszert:

1. Zenés videók, karaoke programok segítségével szavak tanulása,

2. Tabello használata, ahol a tanuló saját és idegen nyelven is látja a szöveget, s annyiszor hallgatja meg, ahányszor akarja. A tananyag rövid mondatokból áll.

3. Új szavak mellé rajzolás, valamely jellegzetes, szóra jellemző dolgot.

4. Szavakkal való játék is segíthet a memorizálásban, pl. memóriajáték.

5. Memóriamankók, mnemotechnikák (Mező, 2011) használata.

6. Speciális tanulási stratégiák alkalmazásának előnyben részesítése (ld. Mező-IPOO tanulásfejlesztési eljárás, Mező, 2011).

7. Karikatúrák, képregények használata (Szalay, 2016).

8. Névelö begyakorolására színek és mozgásos játékok használata. Pl. Felállsz, ha der, leguggolsz, ha die, hátrafordulsz, ha das a névelője a németül mondott szónak. De lehet tapsolni, koppintani, dobbantani stb.

9. Dalok, mondókák, versek, mesék gyakori használata.

10. Drámatechniákkal kísért kommunikáció. Helyzet- és szituációs gyakorlatok, történetek.

11. Diktafon, okos telefon a visszamondás, visszahallgatás segítése érdekében.

12. Számítógépes programok. Szövegszerkesztő és helyesírásellenőrző programok használata. Nyelvtanuló- és nyelvgyakorló programok.

\section{Konklúzió}

A diszlexiás tanulók esetében is van lehetőség az idegen nyelv tanítására, azonban nemcsak a képességekre kell alapozni, hanem a szükségszerü a fokozott motiváció. Az optimális feszültségi szint fenntartására szükséges, amit cask megfelelő ráhangolással lehet elérni. A német nyelv tanítása során figyelembe kell venni, hogy a kezdő diszlexiás nyelvtanulók szókincse elődlegesen nem az asszociációs szerveződésen, hanem a közvetlen tapasztalaton, az elsődleges fordításon alapszik, emellett a föneveken alapuló értelmezés hangsúlyos. Erre alapozva lehet elkezdeni a diszlexiás tanulók sikeres nyelvtanulását, meg kell keresni minden tanuló esetében az erősségeket, a kapaszkodó pontokat az asszociációk beindításához, $\mathrm{s}$ arra támaszkodva lehet fejleszteni a tanulók nyelvismeretét.

\section{Irodalom}

Bryant, P., \& Bradley, L. (1985): Children's reading problems. Basil Blackwell, London.

Christiansen, A. (2014): Az írás-olvasási és számolási zavarok kezelése. Saxum Könyvkiadó, Budapest.

Csépe, V. (2014) Az olvasás zavarai és a diszlexia. In: Pszicholingvisztika. Akadémiai Kiadó, Budapest, pp. 1325-1343

Dóczi, B. (2006): Mapping the mental lexicon of pre-intermediate learners; word associations in a depth of word knowledge elicitation task. In: Horváth, J. Nikolov, M. (szerk.): UPRT 2007: Empirical studies in English applied linguistics, University of Pécs Roundtable, 117-138.

Kohlmann Á. (2014): Diszlexiások/diszgráfiások anyanyelvi és idegen nyelvi szókincsszerkezete. Pázmány Péter Katolikus Egyetem Nyelvtudományi Doktori Iskola. Budapest.

Luchsinger, R.és Godfrey E. Arnold (1970).The voice and its Disorders. Manual of Voice and speech Medicine.Vienna, Springer Publishing.

Meara, P. (1983): Word associations in a foreign language. Nottingham Linguistic Circular, 11(2): 29-38. 
Meixner Ildikó (2012): A dyslexia prevenció, reedukáció módszere. Meixner alapítvány, Budapest.

Mező F., Mező K., Mező L.,(2011). Tanulógép, Tanulás módszertani javaslatok. K+F Stúdió Kft., Debrecen.

Mezö, F.(2011): Tanulás: diagnosztika és fejlesztés az IPOO modell alapján. K+F Stúdió Kft. Debrecen.

Szalay K. (2016): Nyelvtanulás karikatúrákkal és képregényekkel. Különleges Bánásmód, II. évf., 2016/1. szám, 73-85.

Tánczos J. (2007): Nyelvtanulás és diszlexia. Pedellus Tankönyvkiadó. Debrecen.

Wolter, B. (2001): Comparing the L1 an L2 mental lexicon. Studies in Second Language Acquisition, 23: 41-69

Zhang, S. (2003): Response types and lexical acquisition.Foreign Language Teaching and Research, 4: 275-281.

http://tabello.com/

http://janus.ttk.ptl.hu/tamop/tananyagok/nyelv_elsajatitas/21_nyelvelsajatitasi_elmeletek.html 


\title{
(PRO)AKTIVITÁS EGY NEMZETKÖZI NAGYVÁLLALAT MAGYAR LEÁNYVÁLLALATÁNAK TÁRSADALMI FELELŐSSÉGVÁLLALÁSÁBAN
}

Szerző:

Lázár Tímea

Debreceni Egyetem

Bene Ágnes

Debreceni Egyetem

Első szerző e-mail címe:

lazar.timea@econ.unideb.hu

\section{Lektorok:}

Móré Mariann

Debreceni Egyetem Egészségügyi Kar

\author{
Ásványi Katalin \\ Budapesti Corvinus Egyetem
}

Mező Ferenc

Eszterházy Károly Egyetem

Mező Katalin

Debreceni Egyetem

Lázár Tímea, Bene Ágnes (2017): (Pro)aktivitás egy nemzetközi nagyvállalat magyar leányvállalatának társadalmi felelősségvállalásában. Különleges Bánásmód, III. évf. 2017/4. szám, 77-95. DOI 10.18458/KB.2017.4.77

\begin{abstract}
Absztrakt
A nemzetközi nagyvállatok magyarországi elterjedése, majd a magyar munkavállalók külföldi munkavállalása lehetővé tette a nemzetközi gyakorlatok fokozottabb megjelenését a szervezetek müködésének minden területén. Mivel a szervezetek világszerte folyamatos kihívásokkal szembesülnek, az ezen kihívásokra kifejlesztett és alkalmazott megoldások tárháza bővül. Jelen tanulmány egy német anyavállalat magyarországi leányvállalatának gyakorlatát tárja fel a fogyatékosokkal és megváltozott munkaképességü személyekkel kapcsolatban. Ezen tevékenységek nagyrészt a humánerőforrás gazdálkodással (HR), a kommunikációval, és a vállalat társadalmi felelősségvállalásával (CSR) hozhatók összefüggésbe. A tanulmányban a vállalat konkrét gyakorlata kerül bemutatásra, az új elemek komplexitásának hangsúlyozásával.
\end{abstract}

Kulcsszavak: Interkulturális, HR, CSR, fogyatékos, jó gyakorlat, összetett

Diszciplina: közgazdaságtan

\begin{abstract}
The spread of international companies in Hungary and the employment of Hungarian workers abroad have made it possible for foreign practices to increasingly appear in every field of the organizations' functions. As organizations face continuous challenges all over the world, the range of solutions developed and used to tackle these challenges broadens continually. This paper describes the practice of a Hungarian subsidiary owned by a German parent company towards people with disabilities and those whose work capacity has changed.
\end{abstract}


These activities are in connection with Human Resources, Communication, and more generally the organization's Corporate Social Responsibility (CSR). In the paper the specific practice of the company, focusing the complexity of new issues is described.

Keywords: Intercultural, HR, CSR, disability, best practic, complex

Disciplines: Economy

A fogyatékosság megítélése relatív, általában a „normális”- hoz történő viszonyításon alapszik. Kurucz és Kemény (2015) azt is megállapítja, hogy a határt normalitás és fogyatékosság között általában a nem-fogyatékos emberek képviselöi jelölik ki (Kurucz, Kemény, 2015). A fogyatékos személyek létszáma Magyarországon 2011-es népszámlálás alapján 457 ezer fö, a népesség 4,6\% -a. Minden ötödik munkaképes korú személy valamely tartósan fennálló egészségügyi probléma, vagy egyéb korlátozottság miatt veszélyeztetett (KSH 2012). Az ilyen személyek, a család és szükebb környezet nem képesek önállóan megoldani a sikeres integrációt, sőt az állami beavatkozás sem elégséges. Szükség van a széles körü társadalmi együttmüködésre.

A vállalatok felelősségvállalásának szükségessége megkérdőjelezhetetlen (Kun, 2010). Ezt a vállalati társadalmi felelősségvállalást az Európai Unió a müködés társadalomra gyakorolt hatásaiért vállalt felelősségként definiálja (Sperkens, 2017).

A vállalati társadalmi felelösségvállalás nagy része törvényi szabályozáson kívül esik, az egyes vállalatok gyakorlatát ennél fogva nem a jogszabályok, hanem sokkal inkább a mások által közzétett jó gyakorlatok inspirálják. Az interkulturális vállalatok híd szerepét betöltve alkalmazhatják a különböző kultúrákban (leányvállalataikhoz, telephelyeikhez kötődve) sikerrel alkalmazott gyakorlatukat további helyszíneken.

Jelen tanulmány újszerüségét az adja, hogy ezen CSR területeket írja le egy vállalat gyakorlatának lehetőségek szerinti legteljesebb feltárásán keresztül. Bemutat olyan jó gyakorlatokat, amelyek inspirálhatnak másokat, döntéshozókat és szakembereket saját jó gyakorlatok kialakítására. Olyan keretrendszert is alkalmaz (tevékenységleltár), aminek segítségével meglévő, vagy tervezett tevékenységeket rendszerezhetnek.

A tanulmány első alfejezete a CSR egy haladó koncepcióját járja körül az elköteleződés kötelezettségek mentén. Ezt követően kerül sor a fogyatékos személyekkel és megváltozott munkaképességüekkel kapcsolatos bánásmód néhány aspektusának bemutatására. A Tanulmány második részében a kutatást és annak eredményeit tárjuk fel. Azt kívánjuk bemutatni, hogy milyen konkrét elemei lehetnek a társadalmi felelősségvállalásnak az egyszerü támogatástól a foglalkoztatáson (ami sajnálatos módon a legcsekélyebb súllyal érhető tetten), az összetettebb programokig.

\section{A vállalati társadalmi felelősségvállalás (CSR)}

A vállalati társadalmi felelősségvállalás (CSR, Corporate Social Responsivility) meghatározására évtizedek óta sokan vállalkoznak a nemzetközi és egyre többen a hazai szakirodalomban is, mi több, definíciókat összegző tanulmányok is napvilágot látnak (Dahlsrud, 2008; Csapóné, 2016). Azt, hogy a felelősségvállalást integrálni kell a vállalati müködésbe 1984-ben Peter Drucker, a menedzsment elméletek atyja úgy fogalmazta meg, hogy a társadalmi problémák kezelését gazdasági lehetőséggé kell formálni (Drucker, 1984).

A felelősségvállalás melletti elköteleződés üzleti szempontból is jelentős megtérülést hozhat (Rayner, 2003). A megtérülés több szinten értelmezhető, mert nem csak a gazdasági 
megtérülés jelenthet hasznot a vállalatok számára, hanem a társadalmi elfogadottság és a társadalmi értékek létrehozása is. Az etikus viselkedés és a gazdasági fejlődéshez való hozzájárulás iránti elköteleződéssel párhuzamosan az ilyen vállalat javítja munkavállalóinak és családjaiknak életminőségét, csakúgy, mint a helyi közösségét és általában a társadalomét (Watts, Holme, 1998).

A kötelezettségek és elvárások irányából megközelítve a CSR „a vállalat oly módon való müködtetése, amely megfelel a vállalatokkal szemben a társadalom által támasztott etikai, jogi, üzleti és társadalmi elvárásoknak vagy túlteljesíti azokat” („Business for Social Responsibility" szervezetet idézi Perrini, 2006, 307.). Általánosan, az érintettek oldaláról tekintve, a vállalati társadalmi felelősségvállalás a vállalatok kötelezettsége, hogy müködése során kielégítse az érintettjei igényeit (Waddock, és tsai, 2002).

Az Európai Unió új, EU CSR 3.0 meghatározásának folyamata jelenleg is zajlik. Ennek fókuszában a közös értékteremtés áll. További kulcsfogalmai: átláthatóság, befogadás, és a foglalkoztatás (Sperkens, 2017).

A CSR stratégiák kategorizálására már az 1970-es években születtek modellek. McAdams (1973) és Wilson (1975) modelljeiben is a vállalat CSR-hez kapcsolódó attitüdje egy kontinuum mentén helyezhető el. Az utóbbiban a CSR stratégiai gondolkodás legmagasabb szintjét a proaktivitás (proactive) jellemzi. Ez a szint McAdams 4 lépcsős evolúciós modelljében a 4. „vezető szerep”-ként definiálható (Become leader in the field), ekkor a vállalat túllépve a minimális elvárásokon vezető CSR szerepre vállalkozik ( McAdams (1973) és Wilson (1975) idézi Barabel, és tsai 2010. 195.o.).

Az 1990-es évektől a CSR-ról szóló viták középpontjában is az áll, hogy a vállalatoknak át kell alakítaniuk szemléletüket a megfelelés szintjéről az elkötelezettség irányába, a károk minimalizálásából az értékteremtés felé (Luetkenhorst, 2004; Novak, 1996).

Ásványi (2014) a vállalatokat (eredetileg adományozási motivációik alapján) tipizálva írja le a haszonszerzési és a külső-belső motivációk dimenzióiban (1.ábra). Ebben a modellben az elkötelezett vállalat célja a felelősségvállaláson keresztül nem elsősorban üzleti haszonszerzés, sokkal inkább a társadalom érdekeit veszi figyelembe. Tevékenységeik hátterében felelősségtudat áll (Ásványi, 2014). A felelősségtudat és elkötelezettség bázisán létre jöhet az értékteremtés.

A közös értékteremtés jelentőségét tárgyalja Csapóné is egy 2016-os vállalati esettanulmányában. A munkatársak, mint a vállalat stratégiai erőforrása, a serkentő szervezeti kultúra, a jó gyakorlatok megosztása biztosíthatják a hosszútávú folyamatos és közös értékteremtést (Csapóné, 2016).

A CSR tevékenységek célcsoportja lehet a szervezeten belül (munkavállalók), és a szervezeten kívül (helyi közösségek, szükebb környezet, tágabb környezet), vagy történhet egy általános társadalmi „közjó”(emberiség, a Föld, példamutatás) érdekében (Bene, 2016).

A vállalatok jelentős része időszakos jelentésekben teszi közzé CSR tevékenységét.

2015-ben az ENSZ Fenntartható Fejlődési Csúcstalálkozón új globális fejlődési programot fogadtak el fenntarthatósági célrendszer kidolgozásával. Ez elsősorban egy általános, nemzeteken túlmutató célrendszer, a továbbiakban régiós, és országos szinten is értelmezhető célokkal és feladatokkal (Faragó, 2015). A 17 Fenntarthatósági cél (Sustainable Development Goals, SDG-s) rendszerét (1. számú függelék) nemzetközi és hazai nagyvállalatok is elkezdték orientációs bázisként használni Fenntarthatósági Jelentéseikben (pl. Bosch, Lexon, Vodafone, Magyar Telekom). 
1 ábra: Vállalatok típusai az adományozások mozgatórugói alapján

(forrás: Ásványi, 2014, 39. o.)

Van haszonszerzési cél

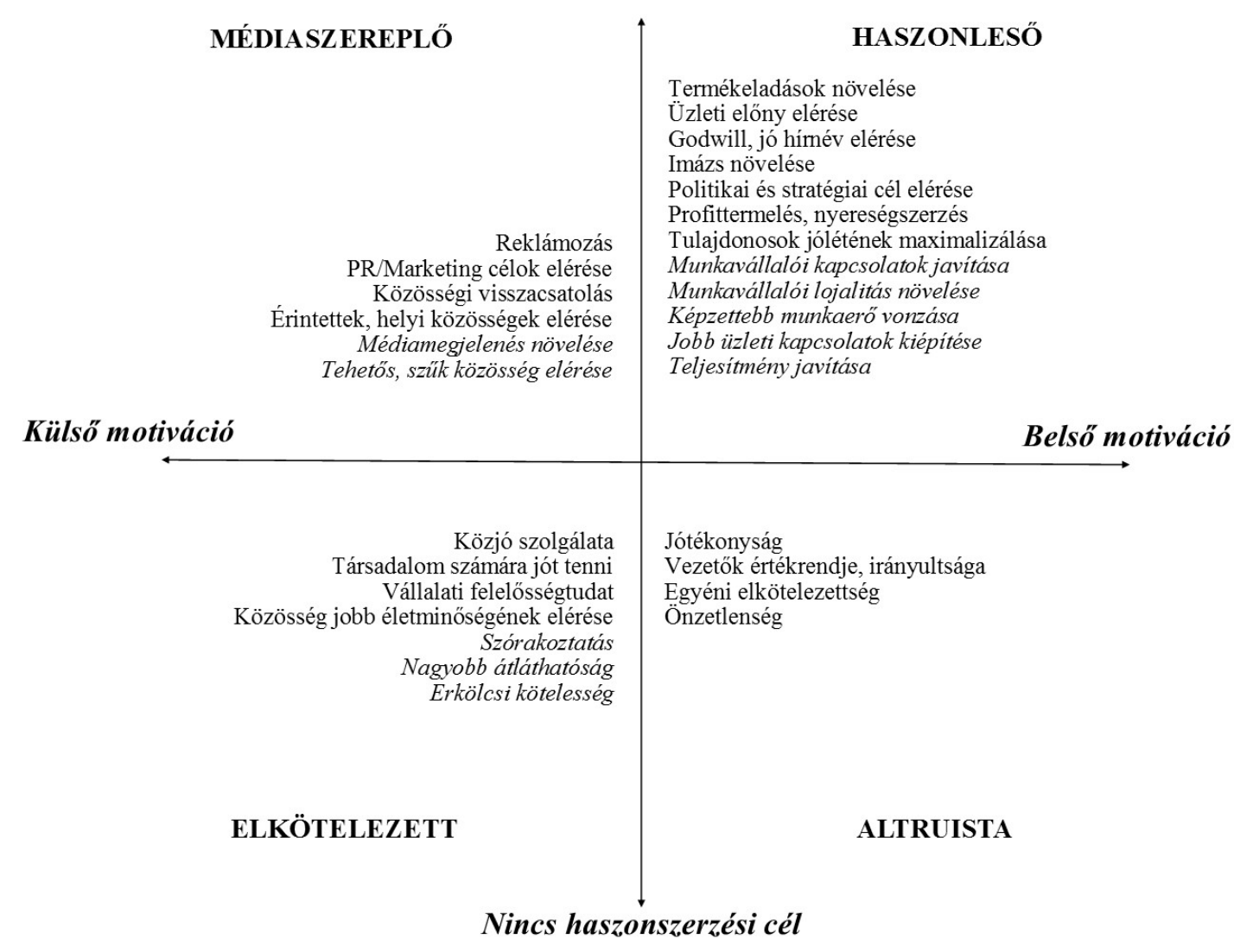

Jelen tanulmány a vállalat társadalmi felelősségének szükebb területére fókuszál, ami a fogyatékos személyekkel, megváltozott munkaképességüekkel való bánásmóddal kapcsolatos tevékenységeket öleli fel.

\section{Fogyatékossággal élők, megváltozott munkaképességúek és a vállalatok}

A fogyatékos személyekkel kapcsolatos legmagasabb szintü jogszabály a Fogyatékossággal élő személyek jogairól szóló egyezmény és az ahhoz kapcsolódó Fakultatív Jegyzőkönyv kihirdetéséről szóló 2007. évi XCII. törvényben foglaltak szerint: „Fogyatékossággal élő személy minden olyan személy, aki hosszan tartó fizikai, értelmi, szellemi vagy érzékszervi károsodással él, amely számos egyéb akadállyal együtt korlátozhatja az adott személy teljes, hatékony és másokkal egyenlő társadalmi szerepvállalását" (2007. évi XCII. törvény, 1. cikk). Megváltozott munkaképességü személynek az tekinthető, aki testi vagy szellemi fogyatékos, vagy akinek az orvosi rehabilitációt követően munkavállalási és munkahely-megtartási esélyei testi vagy szellemi károsodása miatt csökkennek (Szabó, Kozicz és Ottrok, 2012).

A Munka Méltósága című munkajogi projekt keretében a fogyatékossággal élők foglalkoztatási helyzetét is vizsgálták. Jelentésükben rámutatnak, hogy a hazai jogrendszerben nem létezik egységes definíció a fogyatékos személy meghatározására. A megváltozott munkaképességü személy fogalomkör tág, és több homogén csoportot foglal magában, az 
egyes csoportokon belül is jelentős eltérések lehetnek az egészségkárosodás, illetve a fogyatékosság mértékét illetően. A vizsgálatban résztvevő szervezetek ajánlása, hogy kerüljük a fogyatékkal élő személyek szóhasználatot (Szabó, Kozicz és Ottrok, 2012).

Jelen tanulmány a fogyatékos, fogyatékossággal élő és megváltozott munkaképességü kifejezéseket használja. A megváltozott munkaképességűek köre tágabb, azonban ez a fogalom csak korlátozott körben használatos, elsősorban a szabályozói és beszámolói elvárások területén. A CSR tevékenységek (az alkalmazáson túl) célcsoportja egyértelmüen a fogyatékos személyek és a hozzájuk kapcsolódó intézmények, programok, projektek köre.

A megváltozott munkaképességüek munkaerő-piaci lehetőségei összességében erősen behatároltak, tíz érintettböl mindössze kettő dolgozik. Százezres nagyságrendüre becsülik azon érintettek számát, akik célirányos intézkedésekkel, pl. atipikus foglalkoztatási formák elterjesztésével, a közlekedés megszervezésével, munkaállomás kialakításával foglalkoztathatók lennének (KSH 2012). Új munkavállalási lehetőségek feltárására van szükség, újszerü, rugalmas foglalkoztatási formák alkalmazásával lehet elősegíteni a megváltozott munkaképességü emberek munkaerő-piacra való beilleszkedését (Kun, 2010).

A morális akadálymentesítés (Kálmán és Könczei, 2002) az első legfontosabb lépés, abban a folyamatban, amelynek egyik állomása a megfelelő pozíció felkínálása egy megváltozott munkaképességü, vagy fogyatékos személynek. A vezetésnek a kommunikációs munkatársaknak és a humánerőforrás (HR) részleg dolgozóinak kulcsszerepe van a szemléletformálásban. A fogyatékos munkavállalók alkalmazása nem csak az alkalmazott személyre és szükebb környezetére van hatással, hanem az alkalmazó vállalatra, annak megítélésére és áttételesen az egész munkaerőpiacra (Kun, 2010, Kemény, 2015).

Abban a vállalatok és a témával foglalkozó szakemberek is egyetértenek, hogy a meglévő munkatársakat fel kell készíteni a fogyatékos vagy megváltozott munkaképességü kolléga fogadására. Ennek a felkészítésnek a célja az elfogadó, befogadó szemlélet kialakítása, elősegítése. A szakemberképzés, érzékenyítő tréningek biztosíthatják a megfelelő szakmai hozzáértést, és főként az utóbbi a szemléletformálást (Dajnoki, 2014). Szintén lényeges az információ - áramlás elősegítése, a jó gyakorlatok megosztásával. Ilyen jó gyakorlat lehet egy beillesztési program, egy mentor program (Csukonyi, és tsai 2007, Kun, 2010, Móré , 2012).

A jó gyakorlatok megosztásában szintén fontos szerepet kapnak a HR szakemberek. Fórumai lehetnek a különböző HR szakmai találkozók, internetes szakmai oldalak, ahol gyakran különböző szervezetek HR vezetői adnak tanácsot, és osztják meg tapasztalataikat más kollégákkal (Móré, 2012).

A jó gyakorlatokra felhívhatja a figyelmet például egy védjegy. A Fogyatékosság - barát munkahely védjegyet brit mintára vezették be (2. ábra).

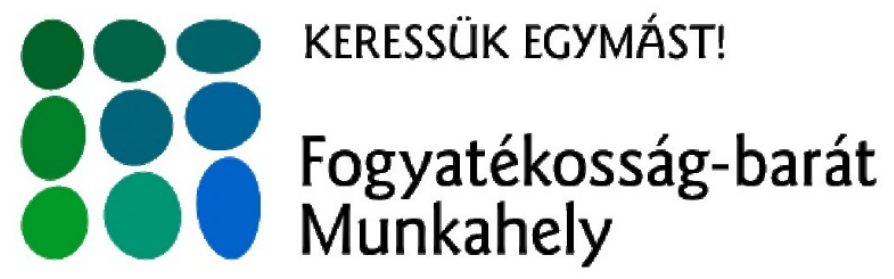


Minden évben az Emberi Erőforrások Minisztériuma, az American Chamber of Commerce in Hungary, a Szövetség a Kiválóságért Közhasznú Egyesület és a bevezető Salva Vita Alapítvány adja át a pályázati feltételeket teljesítő munkáltatóknak . A Fogyatékosság-barát Munkahely logó, - mint védjegy használatát elnyerő munkáltatóknak az Európai Minőségmenedzsment Alapítvány (EFQM) Kiválóság Modellje alapján kidolgozott koncepciónak kell megfelelniük (2.ábra).A díjat azon szervezetek nyerhetik el, amelyek vállalják, hogy folyamatosan fejlesztik a fogyatékos munkavállalók toborzásával, foglalkoztatásával, megtartásával kapcsolatos gyakorlatukat. A nyertes pályázó az elismerés megszerzését követően két évig használhatja a Fogyatékosságbarát Munkahely logót (Net5).

A gazdasági megfontolások mellett (Roberts és tsai 2004; Fedor, Münnich és Sipos, 2007; Dajnoki, 2014; Net9), a vállalati társadalmi felelősségvállalással összefüggésbe hozható fogalmakat, mint a vállalati arculatot, a szervezeti kultúrát, vállalati filozófiát, a vállalati értékeket tekinti számottevőnek a szakirodalom (Roberts és tsai 2004; Kun 2010; Bene 2016) elsősorban a fogyatékosok és megváltozott munkaképességüek alkalmazásának területén.

Ha az alkalmazáson kívül eső (nem ritka, hogy ezek végül alkalmazáshoz vezetnek) fogyatékosokkal és megváltozott munkaképességüekkel kapcsolatos tevékenységeket szeretnénk számba venni, nem áll olyan széles körü szakirodalmi bázis rendelkezésre. Főként esettanulmányok formájában, jó gyakorlatok bemutatásával lehet találkozni (Althoff, 2007; Bene, 2016).

A tematikus napok, vállalati rendezvények, a különböző munkavállalói csoportok vagy ügyfelek, partnerek, esetleg beszállítók számára szervezett képzések hozzájárulhatnak a befogadó kultúra kialakításához (Tardos, 2015). Az ilyen alkalmakat használhatják fel arra a munkáltatók, hogy felmérjék a célcsoporttal szembeni attitüdöket munkavállalóik körében. Gyakori, hogy fogyatékos vendégeket hívnak meg, bevonva öket a tematikus nap történéseibe. Megjelenhetnek meghívott résztvevőként, termékeiket, alkotásaikat kínáló eladóként, fellépőként prózai, zenés, vagy táncos müsorral. Beszámolhatnak élethelyzeteikről, sikereikröl (pl. paralimpikonok), vagy létrehozhatnak közös munkával értéket a dolgozókkal például egy mühelymunka (workshop) keretében (Bene, 2016).

Segítő vásárlásról akkor beszélünk, ha fogyatékos, megváltozott munkaképességü emberek által készített terméket vásárolunk, vagy szolgáltatás értékesítéséhez járulunk hozzá, vagy azt vásárolunk (3.ábra).

\section{1. ábra: Segitő vásárlás védjegy (forrás: Net6)}

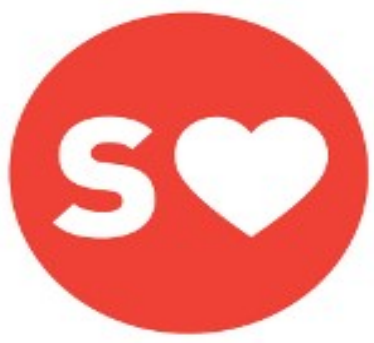

Ez történhet szervezett formában a vállalatok telephelyein, más érzékenyítő programokkal összekötve. Szolgáltatások esetében szintén történhet a vásárlás a vállalat telephelyén, de 
gyakrabban a szolgáltatóhoz inkább kapcsolódó helyszínen, egy szállodai komplexumban, egy étteremben. Ilyen vállalkozás a Hotel Panda Budapesten (Net7), a Hatpöttyös étterem Székesfehérváron (Net8), vagy a Neo Interactive digitális reklámügynökség (Net9). A Kockacsoki csokoládémanufaktúra az édességek mellett táborokat, tanfolyamokat kínál (Net10). A Segítő Vásárlás nevet viselő programot az Emberi Erőforrások Minisztériuma 2010-ben indította el annak érdekében, hogy felhívja a figyelmet a fogyatékossággal élő emberek közremüködésével készített termékekre és szolgáltatásokra. 2013-ban védjegyet jegyeztek be a programhoz (Net6).

A védjegyet a megváltozott munkaképességü embereket foglalkoztató akkreditált, védett munkáltatók használhatják termékeiken, tanúsítva, hogy ezek a termékek megváltozott munkaképességüek közremüködésével készültek. Egy design projekt is elindult 2014. júniusától azzal a célkitüzéssel, hogy a kortárs ízlésnek megfelelö, piacképes termékek készüljenek a fogyatékossággal élőket foglalkoztató mühelyekben formatervezőkkel együttmüködve (Net6).

A para-sport támogatása a sportrendezvények támogatásától a nemzeti válogatottak, szövetségek, csapatok az egyéni sportolók támogatásán át a tömegsport támogatásáig terjed a sporttevékenységen innen és túl. Ugyan a vállaltok a sport szponzorációt elsősorban marketing eszközként használják, de a para-sport támogatásának filozófiai hátterében hangsúlyosan megjelenhet az esélyegyenlőség, a társadalmi integráció serkentése. Mivel a sporttevékenység, a sportfogyasztás fokozott emóciós töltettel jár, különösen alkalmas pozitív üzenetek terjesztésére, szemléletformálás közvetítésére (Althoff, 2007).

Az olyan marketingtevékenység önmagában társadalmi célúnak tekinthetö Donovan és Hanley (2010) szerint, aminek egyik célja lehet, hogy társadalmi jót célzó tudatosságot, pozitív attitüdöt, alakítson ki, illetve ösztönözzön (Donovan, Henley 2010, idézi Balázs, Koncz, 2016. 13.o.). Az esélyegyenlőség, a befogadás és elfogadás ösztönzése társadalmi célúnak tekinthetö.

Jelen tanulmány az alkalmazással és az alkalmazáson túl megvalósuló, fogyatékos személyekkel és megváltozott munkaképességüekkel összefüggő CSR tevékenységek körének rendszerezésére vállalkozik egy nemzetközi nagyvállalat magyar leányvállalatának tevékenységének bemutatásán keresztül, a teljesség igényével a módszertani korlátokat figyelembe véve. Nem tárgyaljuk ennek kormányzati (mint minisztériumi felelösségi körök, díjak, részletesen pl.: 1025/2006.(III.23) Kormányhatározat ) és gazdasági (pl. rehabilitációs hozzájárulás, részletesen: 2011. évi. CXCI. Mmtv.) aspektusait.

\section{Módszer}

Szekunder adatokra alapozott másodelemzést valósítottunk meg.

A kutatásban alkalmazott kevert módszertan kiválasztásakor figyelembe vettük azt a kutatásmódszertanban pragmatista hozzáállást, miszerint a társadalmi jelenségek vizsgálatánál a hangsúly a módszertanról és a kutatási eljárásról áttevődik a vizsgálandó problémára. A probléma megértéséhez, feldolgozásához minden rendelkezésre álló elméleti felfogást és módszertani keretet fel lehet használni (Creswell, 2009). Géring (2017) hiánypótló módszertani tanulmányában részletesen bemutatja, hogyan lehet szövegelemző módszerekkel vállalati társadalmi felelősségvállalást, mint társadalmi jelenséget, honlapok elemzésével megvalósítani. A szerző szintén ebben az írásban részletezi, a kevert módszertan, azaz a kvantitatív tartalomelemzés, és egy kvalitatívabb fókuszú diskurzuselemzési eljárás alkalmazásának előnyeit. Nem csupán egyes szavak, hanem általánosabb témák, programok és kezdeményezések megjelenését is vizsgáltuk. Ezért azt is mondhatjuk, hogy a webtartalomelemzés Herring (2009) által bemutatott különbözö kutatási területei közül ez a kutatás a szövegek (vállalati honlap) témastruktúrájának feltárására is irányult, de nem terjedt 
ki az imázselemzésre, a linkelemzésre, a szövegjellemzők, vagy a szövegek közötti hivatkozási rendszerek elemzésére.

Az elemzési egység a teljes vállalati honlap volt, melynek elemzése során a honlapszövegeket és a letölthetö anyagokat (pl. jelentések, sajtóközlemények) egyaránt figyelembe vettük. Jelen vizsgálat során az elemzési egység részét képezték a nem magyar nyelvü tartalmak is, de azzal a kikötéssel, hogy a magyar leányvállalat tevékenységéhez kapcsolódjanak.

A kialakított vizsgálati szempontrendszer 4 fókusz köré rendeződik:

1. a vállalati kommunikációban megemlített érintetti csoportok feltárása,

2. a vállalati felelősségvállalás fogyatékossággal élőkhöz, megváltozott munkaképességüekhez bármely módon kapcsolódó különböző témáinak, területeinek megjelenése, időbeli változása a vizsgált időszakban,

3. a különböző vállalati programok megjelenése (tevékenységleltár elemei),

4. összetett programok, amik érintenek fogyatékossággal élő vagy/és megváltozott munkaképességü személyeket.

Az alkalmazott tartalomelemzés és diskurzuselemzés a hozzáférhetőséget prioritásként kezelve kiterjedt:

- a magyarországi vállalati honlapra (Net1),

- a német anyavállalat honlapjára (Net2).

A honlapok vállalati társadalmi felelősségvállaláshoz kapcsolódó felületei változó mértékben naprakészek, indokolt volt külön figyelmet fordítani a honlapon elérhető 2016-os és 2017-es hírfolyamokra és a kapcsolódó letölthető releváns sajtóközlemények elemzésére. Ezek:

- Éves jelentés 2016.,

- Fenntarthatósági Jelentés 2014.,

- Fenntarthatósági Jelentés 2015.,

- Fenntarthatósági Jelentés 2016,.

- A Vállalat esélyegyenlőségi terve a 2016. január 1-től 2020. december 31-ig terjedő időszakra

- Egyéb internetes tartalmak (pl. youtube) voltak.

Az eredmények strukturálásának vezérfonalát Bene (2016) tevékenységleltár rendszere határozta meg. A struktúra segítséget nyújtott a tevékenységek szisztematikus bemutatására.

\section{A vállalat gyakorlata - CSR tevékenységek a fogyatékos személyekkel és megváltozott munkaképességüekkel kapcsolatba hozható területeken}

Az alábbiakban egy multinacionális nagyvállalat magyar leányvállalatának azon tevékenységeit tárjuk fel, amelyek fogyatékosokkal, megváltozott munkaképességüekkel való bánásmódhoz köthetők. A vizsgálat elsősorban a közelmúlt és jelenlegi tevékenységeire fókuszál.

A vizsgálat vállalat Magyarország legnagyobb távközlési szolgáltatója. Telekommunikációs és infokommunikációs (ICT) szolgáltatásokat nyújt vezetékes és mobil viszonylatban, adatátviteli és nem hangalapú, informatikai és rendszerintegrációs területeken. A vállalat egy német anyavállalat magyar leányvállalata. 
- Jövőképük: „Elsők vagyunk és elsők is maradunk.”(Net1)

- Küldetésük: „Érthetőbbé és elérhetőbbé tesszük a digitális világot. Mindenkinek biztosítjuk a könnyebb, színesebb és sikeresebb élet lehetőségét.”(Net1)

2016. december 31-ével az alkalmazottak átlagos statisztikai állományi létszáma: 6221 fó volt. Az egész vállalatcsoportot érintő 2014-ben bejelentett 1000 föt meghaladó létszámleépítés 2016-ra is elhúzódott.

A Vállalat legutóbbi, 2016-os Fenntarthatósági Jelentésében csakúgy, mint korábban, külön fejezetben rendszerezi az érintettekhez kapcsolódó tevékenységét társadalmi felelősségvállalásának jegyében.

A vállalat érdekelt feleinek (stakeholder) körébe azok a csoportok tartoznak, amelyek hatással vannak céljainak megvalósítására, vagy érdekeltek abban (4. ábra). „Irányítási rendszereinek és benchmarkvizsgálatainak áttekintésével azonosította az érdekeltek körét, és állandó kapcsolatot tart velük, hogy érdekeiket müködése során figyelembe vegye" (Vállalat Fenntarthatósági Jelentés 2016., 10. o.).

\section{4. ábra: A vállalat érdekelt felei}

forrás: saját szerkesztés a Vállalat Fenntarthatósági Jelentés 2016., 10. o. alapján

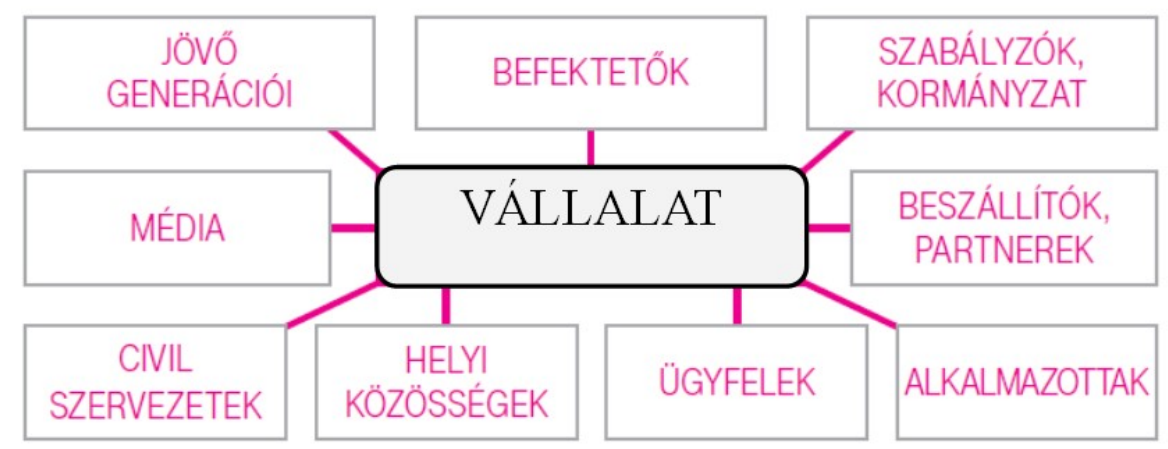

A Fenntarthatósági jelentéshez kapcsolódva évente végeznek kérdőíves kutatást stakeholdereik körében a fenntarthatósági témák fontosságát illetően. Arra kérik a kitöltőket, hogy számszerüsítsék a vállalat fenntarthatósági teljesítményének megítélésére gondolva egy 5 fokú Likert skálán mennyire tartják fontosnak az egyes témaköröket.

A fogyatékossággal élőkkel és megváltozott munkaképességüekkel kapcsolatba hozható CSR tevékenységek az alábbi témákban érhetők tetten ebben az értékelésben:

A. Emberi jogok, esélyegyenlőség

B. Munkahelyi egészség és biztonság

C. Munkatársaink a társadalmi felelősségvállalásban

D. Adományozás

E. Beszállítóink elismerése pl. Delfin díj (korábban Delfin díj a felelős vállalatoknak)

Az utóbbi években egységesen a legmagasabb átlag pontszámokat az emberi jogok, esélyegyenlőség (A), és a munkahelyi egészség és biztonság (B) kapták (adattábla a 2. sz. függelékben). 
A 2016-os Fenntarthatósági Jelentésben fenntarthatósági témáik lényegességi besorolását közlik. Jelen tanulmány szempontjából releváns témák és lényegességük ebben a rendszerben:

- Magas prioritású témák: Munkatársak bevonása; Digitális felzárkóztatás; Ügyfél elégedettség; Emberi jogok, esélyegyenlőség

- Közepes prioritású témák: Munkatársaik a társadalmi felelősségvállalásban; Ügyfélpanaszok kezelése; Ügyfeleik bevonása; Biztonságos mobilhasználat, elektromágneses terek; Delfin Díj a felelős vállalatoknak

- Alacsony prioritású témák: Munkahelyi egészség és biztonság; Ügyfeleik tájékoztatása; Szponzorálás;

A vállalat kedvezményes díjcsomagot kínál az érintett érdekvédelmi szervezetek tagjainak, amelyek: MEOSZ (Mozgáskorlátozottak Egyesületeinek Országos Szövetsége), MVGYOSZ (Magyar Vakok és Gyengénlátók Országos Szövetsége), ÉFOÉSZ (Értelmi Fogyatékossággal Élők és Segítőik Országos Érdekvédelmi Szövetsége).

A honlapok és hírfolyamok elemzése alapján összeállítható egy széles spektrumú tevékenység rendszer. A Függelék 3. ábrája egy korábbi tanulmány (Bene 2016) alapján összefoglalja a vállalati társadalmi felelősségvállalás azon tevékenységeit, amelyek fogyatékossággal élőkkel és a megváltozott munkaképességüekkel való bánásmódhoz köthetőek. Ezen struktúrát használva vezérfonalként a vállalat belső (vállalaton belüli) és külső ilyen tevékenységeit foglaljuk össze a következőkben.

\section{Alkalmazás}

A vállalat - monitoring által elismerten - teljesítette a 2013-ban elnyert Fogyatékosság barát Munkahely címre beadott pályázatában tett kétéves vállalásait. A Fogyatékos Emberek Világnapján megrendezett „Jobb velünk a világ!” gálaesten osztották ki a 2015. évi Fogyatékosság-barát Munkahely díjakat. A cím elnyerésével újabb két évre jogosulttá váltak a „Fogyatékosság-barát Munkahely ” logó használatára.

Az atipikus foglalkoztatási formák egyre szélesebb alkalmazásával a fogyatékossággal élök (elsősorban mozgásukban korlátozottak) és megváltozott munkaképességü dolgozók speciálisabb igényeinek való megfelelés mellett azt is támogatja vállalat, hogy a családosok egyenlő eséllyel állhassanak helyt munkavállalóként és szülőként, nagyszülőként is. Stratégiailag is fontos a vállalat számára, hogy a vállalati kultúra részévé váljon a távmunka, ehhez számos, a napi müködésbe épített gyakorlat, illetve a távmunkavégzést speciálisan támogató nagy légterű iroda, a „Future Work” is hozzájárul. A 2012 óta havi rendszerességgel meghirdetett „Dolgozz otthonról!” felhívás nyomán folyamatosan növekszik az adott napon távoli hozzáféréssel munkát végzők létszáma. 2017. június elsején indult a „Távmunka a Vállalatnál. Te is változtatnál a világon? Tedd velünk!” kampány reklámfilmekkel, távmunkában dolgozó egy-egy kolléga napját elmesélve.

\section{Akadálymentesités}

2016 májusára újult meg a vállalat honlapja. A nem látók és gyengén látók igényeit szem előtt tartva a vállalati portálon több száz oldal könnyebben használható felolvasószoftverrel is. $\mathrm{Az}$ eÁSZF (elektronikus Általános Szerződési Feltételek dokumentum) akadálymentes üzemmódban is elérhetővé vált 2016 végére.

A IX. Fenntarthatósági Napon 2016. szeptember 24-én, az akadálymentesítés, és az esélyegyenlőség, jegyében is jelentek meg kiállítók. Az egyik szekcióbeszélgetés témája a Smart-eszközök szerepe az akadálymentesítés területén-volt. Díjat nyert (közönségszavazat 3. hely) a mozgássérültek sportolását segítő Suhanj! Alapítvány. 


\section{Egészségmegörzés}

A vállalat munkahelyi egészségvédelmi és munkabiztonsági politikájában stratégiájával összhangban egészségterv kidolgozása és müködtetése, egészségmegőrző és megelőző programokat szervezése mellett kötelezte el magát.

2015-ben is megszervezte a hagyományos „Egészséghét” programját a munkavállalók egészségének megőrzéséért. A 2015. évi program mottója: „1 hét kiemelt figyelem az egészségre, fókuszáltabb figyelem a stressz kezelésére" volt. Ennek keretében stresszszürések, lelkiegészség-programok, előadások, tréningek, pszichológus részvételével egyéni konzultációk során volt lehetőség tájékozódni a témában vagy segítséget kérni igény esetén. Komplex stresszfaktorszürésre (online stresszteszt, valamint müszeres orvosi és laboratóriumi vizsgálatok elvégzésére) 6 budapesti és 5 vidéki helyszínen került sor. Az online stresszkérdőívet 1076 munkatárs töltötte ki, orvosi és laborvizsgálaton 708 fö vett részt. 2016ban már 8 város 18 helyszínén zajlott a program egy hónapos „Egészséghetek” néven „Okosan élünk, okosan dolgozunk” mottóval.

A vállalat 20 éve a Vivicittá Városvédő Futás névadó szponzora. A futóversenyhez belső és külső kampányok kapcsolódnak. Egyik, a tömegsportrendezvényhez kapcsolódó projektjük keretében a Suhanj Alapítvánnyal közösen teszik lehetővé a részvételt fogyatékos személyeknek önállóan, speciális segédeszközzel, vagy ép kísérővel.

\section{Belsö kampány, akció}

A vállalat és a Fenntarthatósági Média Klub (FMK) tagjai Adni Jó! Sütiakció néven jótékonysági sütemény-vásárt rendeztek az Önkéntesség Világnapján, 2016. december 5-én. Ennek keretében a vállalat önkéntes dolgozói és az FMK tagjai saját készítésü süteményeiket kínálták eladásra országszerte 15 helyszínen, a vállalat telephelyein. A süteménykért felajánlott, a becsületkasszába befolyt bevételt jótékony célra ajánlják fel, így idén az Autistic Art Alapítvány múvészetterápiás programját támogatják vele.

\section{Etikai kódex, formalizált esélyegyenlöség}

A Csoport Szociális Chartája, valamint a mindenkor hatályos Esélyegyenlöségi terve rögzíti a vállalatcsoport általános emberi jogi alapelveit.

Létezik a vállalatnál egy a belső ellenőrzésekre vonatkozó etikai kódex is.

A vállalat egyike volt azon magyar vállalatoknak, amelyek csatlakozásukkal deklarálták a sokszínüség, mint alapérték melletti elkötelezettségüket 2016-ban, amikor Magyarország is csatlakozott az Európai Sokszínüségi Kartához.

\section{Segítő vásárlás}

A vállalat megújítja az üzleteiben dolgozó értékesítő munkatársak formaruháját. Az új formaruha egyik fontos tartozéka egy olyan hernyóselyem kendő, amelyre az Autistic Art Alapítvány müvészeti programja keretében alkotó autista fiatalok rajzai kerültek. Az első közel 100 darab ilyen sálat Gyenes András, a vállalat lakossági szolgáltatások vezérigazgatóhelyettese és Bella az Alapítvány ügyvezetője adta át a vállalat üzletvezetőinek Kecskeméten 2016. szeptember 29-én.

Az Autistic Art dizájnmárka a fiatalok müvészeti foglalkozásokon készítettek rajzaikra épül, amelyekből designerek bevonásával készítenek magas münőségü termékeket. A márka célja egyrészről a forrásteremtés, másrészről az, hogy megmutassa autista fiatalok közremüködésével is készülhetnek minőségi tárgyak, tehát ők is hasznos tagjai lehetnek a társadalomnak. Az Autistic Art termékek eladásából az Alapítvány 16 évesnél idősebb autisták számára létrehozott 11 bentlakásos otthon müködését támogatja, ahol több mint 200 fiatalt látnak el. 


\section{Pénzbeli támogatás intézménynek, szervezetnek}

A vállalat a sütemény-vásár mellett további lehetőségeket kínál azoknak, akik csatlakozni szeretnének a jótékony célú adományozáshoz, és szívesen támogatnák az autista fiatalok művészetterápiás programját. Egy foodstylist és ételfotós páros fotókat készített a sütemények felhasználásával a vállalat budapesti Krisztina Körúti Székházába, amelyekből elektronikus formájú képeslapok lettek. Ezeket a képeslapokat bárki elküldhette szeretteinek, vagy üzleti partnereinek a vállalat tematikus karácsonyi honlapján keresztül 2016. december 14-24. között. A vállalat minden képeslap elküldése után 100 forintot adományozott az Autistic Art Alapítványnak. A kampányba az Instagram-os megosztásokat is bekapcsolták.

A hello holnap! applikáción keresztül az adományozási időszakokban a felhasználók pontokat gyüjthetnek, amiket forintra váltva adományozhatnak a megjelölt civil szervezeteknek. A rendszer a 2014-es fenntarthatósági Napon debütált. 2017 első adományozási időszakában a 9 szervezet közül 3 fogyatékkossággal élőket támogató szervezet. Ezek, az autizmussal élőket támogató Autistic Art, az Artman Mozgásterápiás Művészeti Közhasznú Egyesület, ami azzal a céllal alakult, hogy oktatási, müvészeti és terápiás programok létrehozásával segítse a különböző fogyatékossággal élő emberek társadalmi felzárkóztatását és a Suhanj! Alapítvány amely 2010 óta osztja meg a mozgás örömét sérült és fogyatékkal élő személyekkel.

\section{Pénzbeli támogatás magánszemélynek}

A vállalat támogatja Adámi Zsanett paralimpikon úszót. A 2016-os riói nyári paralimpia ideje alatt üzemeltette az egyekvagyunk.hu oldalát, amely segítségével 2016. szeptember 7 és 18-a között szívdobbanást küldhettek az ügyfelek, vagy üzenetet a parasportolóknak is Rióba. A szív alakú okoseszköz Adámi Zsanett paraúszónál jelezte a szurkolók biztatását.

\section{Program támogatása}

A vállalat a magyar sport elkötelezett partnereként és a magyar olimpiai csapat platina fokozatú támogatójaként fontosnak tartja, hogy támogassa a hazai paralimpikonokat is, és hozzájáruljon a parasport hazai ismertségének és népszerüségének növeléséhez. Ezért a vállalat együttmüködésről szóló szándéknyilatkozatot írt alá 2016. augusztus 31-én a Magyar Paralimpiai Bizottsággal, amely értelmében a vállalat a következő paralimpiai ciklusban segíti a hazai csapat felkészülését.

\section{Időadomány}

A vállalat önkéntes napot szervezett 2016. október 15-én. Az országos megmozduláson a vállalatcsoport több mint 1000 munkatársa és családtagjaik vettek részt, akiknek köszönhetően 29 helyszín, köztük számos vállalati telephely és közterület, illetve óvodák, iskolák, szociális intézmények, fogyatékossággal élők lakóotthonainak környezete újult és szépült meg. Az esemény keretében elsősorban fákat és bokrokat ültettek a vállalatcsoport munkatársai, de emellett végeztek környezetrendezési, valamint karbantartási munkálatokat is. Így a nap végére több mint 1000 fával és cserjével gyarapodott az ország és a hello holnap! pagony névre keresztelt virtuális erdő, ahova az azonos nevü mobil Facebook applikáció segítségével bárki feltöltheti ország bármely pontján a saját maga által ültetett fát, fákat. Szegeden a Gemma Szociális Szolgáltató Központ és Fejlesztő Iskola területén kertet rendeztek, kerítést bontottak és padokat festettek a vállalat önkéntesei. Miskolcon két helyszínen is dolgoztak, fákat ültettek a Szimbiózis Alapítvány lakóotthonának, továbbá az Autistic Art Alapítvány által támogatott Miskolci Autista Alapítvány Szakáld községben lévő lakóotthonának területén is. 
Kérés, egyedi adomány

A Hallás Társasága Alapítvány kezdeményezésére több mint 10 millió forint értékü támogatással segíti egy több vállalatból álló alkalmi mecénás klub a nagyothalló fiatalok felsőoktatásban való eredményes részvételét. Az összefogás eredményeként 2015-ben 5 fiatalt támogattak. Az eszközök internet-hozzáférését a vállalat, a hallókészüléket egy forgalmazó, a készülékeket egy iparvállalat biztosítja.

\section{Beszállitók értékelése}

A Beszállítók értékelését több rendszeren keresztül is megvalósítják (ECOVADIS, MTKérdőív, Audit, Előminősítés, Supplier score card, GESI).

A beszállítókra alkalmazott kockázatértékelési szempontrendszer elemei között megtalálható a beszállítóra vonatkozó: alkalmazotti egészség és biztonság; a diszkrimináció.

A bemutatott tevékenység leltárban külön kategóriaként nem szereplö, azonban abba szervesen beilleszthető további tevékenység terület lehet a fogyatékosságokkal, tágabban értelmezve bármely egészséggel, betegséggel kapcsolatos kutatás, vagy fejlesztés támogatása, komplex, kategóriákon átívelő tevékenységek a stratégiai partnerség, és a díjak, elismerések:

\section{Kutatás fejlesztés támogatása, szemléletformálás}

Az anyavállalat által 2016 májusban indított 'Sea Hero Quest' mobiljáték új távlatokat nyit a demencia kutatásában. A játékot az Alzheimer’s Research intézmény, valamint kutatók és játékfejlesztők együttmüködésével fejlesztették. Eddig több millióan játszották már a 'Sea Hero Quest'-et, amit fontos lépésként értékelnek a demencia új, korai diagnosztizálását célzó eszköz kifejlesztése szempontjából. A Sea Hero Quest a világon mindenhol, kortól és nemtől függetlenül tesztelte az emberek tájékozódási képességét, a kutatócsapat pedig San Diegoban, a Neuroscience 2016 konferencián bemutatta a játékkal begyüjtött adatok elsődleges elemzéséből származó eredményeket.

A 'Sea Hero Quest' játék tükrözi a vállalat világképét, digitális felelősségérzetét valamint innovációs vezető szerepét. "Emberek milliói bocsátottak rendelkezésünkre adatokat, segítve ezzel a demencia elleni küzdelmet. A biztonságos felhőben tárolt, hatalmas mennyiségü adatok révén olyan alapanyagot biztosíthatunk a tudósoknak, amire nagy szükségük van a legkorszerübb kutatások során. A digitalizáció áttörést jelent a közegészségügyi helyzet javításában"- mondta az anyavállalat vezérigazgatója (Net2).

Magyarországon 2016. május 5. és június 30. között futott a kampány, amelynek hatására közel 150 ezren töltötték le a mobiljátékot. Ennek a folyamatnak részeként, a Sea Hero Quest támogathatja a demencia korai felismerését, diagnosztizálását, illetve hatással lehet a demenciás páciensek kezelésére is. A folyamat során a mobiljátékot a páciensek térbeli tájékozódási képességei esetleges javulásának mérésére is fel lehet használni. Felhasználható a kísérleti gyógyszeres kezelések hatékonyságának mérésére is.

A játékra buzdítva 2017 szeptember 21-én jelentette meg a vállalat a youtube közösségi videomegosztó csatornán azt a kisfilmet, amit az első hónapban több mint 50 000-en néztek meg (Net13). A Vasárnap címü rövidfilmet az Alzheimer világnapra készítették azzal a szándékkal, hogy az emberek jobban felfigyeljenek a betegségre és aktívan segítsenek a játékban való részvételükkel. A film végén megjelenő üzenet: „Magyarországon mintegy 250000 ember szenved demenciától, akinek családjára és környezetére is súlyos terheket ró a betegség." A film a vállalati honlapon nem található. 


\section{Stratégiai partnerség}

A vállalat 2016. március 30-án az Autistic Art Alapítvány civil stratégiai partnere lett. A támogatás keretében eszközökkel, önkéntes munkával, kommunikációs felületekkel és szolgáltatások biztosításával segíti a vállalat az alapítvány munkáját. Az Autistic Alapítvány 2010-ben indította el művészeti programját, amelynek keretében lakóotthonokban élő autista fiatal felnőtteknek biztosítanak rendszeres rajzfoglalkozásokat, akik a grafikákon keresztül kommunikálnak a külvilággal és a rajzolás által fejezik ki érzéseiket, gondolataikat, mutatják meg gazdag belső világukat. A több éven át tartó partnerség során a vállalat legfontosabb adománygyüjtő akcióinak kedvezményezettje az Autistic Art - Mosoly Otthon Alapítvány lesz: a 2016-os nagy futórendezvénysorozaton a Vivicittán a vállalat munkatársai valamint a Fenntarthatósági Média Klub tagjai az alapítványért futottak. A vállalat az autizmussal élők számára létrehozott lakóotthonokat, ezáltal az autisták mindennapjait technológiai megoldásokkal, infokommunikációs eszközökkel és szolgáltatásokkal is támogatja, az önkéntesei pedig az otthonok felújításában nyújtanak segítséget. Emellett kommunikációs felületein, a vállalat fesztivál- és sportszponzorációjában, eseményeken, például a Fenntarthatósági Napon, továbbá egyéb formákban is megjelenési lehetőséget biztosít. A hello holnap! applikáción keresztül támogatható egyik szervezet az Autistic Art Alapítvány. 2016 őszén a vállalati székház adott otthon az Alapítvány éves jótékonysági aukciójának. Az aukció keretében a lakóotthonokban élő fiatalok és kortárs müvészek alkotásaira licitálhattak a résztvevők. Az önkéntesség világnapjához kapcsolódó Adni jó! Sütiakció és a karácsonyi jótékony képeslapküldés is az Alapítványt támogatta.

\section{Díjak, elismerések}

2008-ban megalapították a DELFIN Díjat: Díj egy Elkötelezett, Fenntartható, Innovatív Nemzedékért.

A DELFIN Díj odaítélésével a vállalat a fenntartható fejlődés gondolatának népszerüsítését szeretné elősegíteni minden magyarországi vállalat körében, és ezirányú tevékenységüket kívánja elismerni. A díjat a fenntarthatóság terén kiemelkedő szerepet vállalók kaphatják meg, odaítéléséről a beadott pályamunkák alapján szakmai zsüri dönt.

A DELFIN Díjra bármely Magyarországon működő vállalkozás pályázhat már megvalósult projektekkel vagy müködő programokkal. A díjakat (4 kategóriában) az éves Fenntarthatósági kerekasztalbeszélgetéshez kapcsolódva adják át.

Esélyegyenlőség kategóriában 2013 után 2015-ben ismét a JOB Személyzeti Tanácsadó érdemelte ki a díjat, ezúttal a megváltozott munkaképességüek munkaerőpiaci integrációját segítő www.rehabjob.hu portál, Facebook-oldal és blog létrehozásával.

Tudatformálás terén pedig a Hegyvidéki Sportcsarnok és Sportközpont (MOM Sport) társadalmi felelősségvállalási tevékenysége, különösen a halmozottan hátrányos helyzetü sportolóknak rendezett versenyei kapcsán.

2017-ben ugyanezen kategóriában az Alko-soft Szolgáltató Nonprofit Bt. lett díjazott. A cég olvasást segítő eszközök magyarországi forgalmazásával, honosításával, Ingyenes Digitális Könyvtár üzemeltetésével segíti a látássérülteket, emellett kifejlesztette az eRikkancs rendszert, amely lehetővé teszi, hogy a látássérültek a nyomtatott sajtót elektronikusan tudják olvasni számítógépük segítségével.

\section{Összefoglalás}

Jelen tanulmány feltárta egy vállalat társadalmi felelösségvállalásának széles eszköztárát a fogyatékos személyekkel, megváltozott munkaképességüekkel való bánásmód területén a kapcsolódó tevékenységek és jó gyakorlatok felvonultatásával.

A fogyatékos, megváltozott munkaképességü személyekkel, szervezeteikkel kapcsolatos CSR tevékenységek a vállalatoknál a legtöbb esetben szigetszerünek tünnek. Érzékelhető, 
hogy a megváltozott munkaképességüek foglalkoztatásának korlátai vannak, nagyobb arányú foglalkoztatást olyan vállalat tud biztosítani, amely képes megfelelő számú alkalmas munkakört kínálni.

A vizsgált vállalat a tágan értelmezett érintettjeit bevonva valósítja meg a fogyatékossággal élő, a megváltozott munkaképességü munkavállalókkal kapcsolatos CSR tevékenységét.

A jó gyakorlataik között vannak belső, és külső tevékenységek, összetett programok, együttmüködések.

A tanulmány feltárta ezek kapcsolatrendszerét és tartalmát tevékenységleltárat felhasználva vezérfonalként, kevert szövegelemzési módszertant alkalmazva a téma szempontjából releváns dokumentumok és internetes tartalmak esetében.

Bemutatott olyan jó gyakorlatokat, amelyek inspirálhatnak másokat, döntéshozókat és szakembereket saját jó gyakorlatok kialakítására. A vállalat jövőképére hangolva proaktív vezető szerep betöltésére tör a vállalati társadalmi felelősségvállalás jelen tanulmányban vizsgált területein.

Korlátozásként említhető a módszertanból fakadó korlátokon túl az önbevallás szubjektivitása, ami a vállalati társadalmi felelösségvállalás kommunikációjában általánosan jellemző. További vizsgálati módszerek alkalmazása - például interjú vállalati CSR felelős szakemberrel - a témakörök teljesebb kidolgozására adhat lehetőséget. A német anyavállalat hasonló szempontok alapján történő elemzése alkalmat adhat egy szélesebb kitekintésre, további összefüggések, jó gyakorlatok bemutatására.

\section{Irodalom}

Althoff, S. (2007). Das Sportsponsoring der Telekom — und was dahinter steckt In: Althoff S. Exzellentes Sponsoring. Deutscher Universitäts-Verlag, 77-102.

Ásványi, K. (2014). A komolyzenére irányuló CSR vállalati megítélése: Vállalati attitűdvizsgálat Q-módszerrel. Marketing és menedzsment 48:(1), 37-46.

Balázs, K., Koncz, V. (2016). Metaforikus és perspektívaváltást igénylő társadalmi célú reklámok hatásvizsgálata. Alkalmazott Pszichológia, 16(3), 7-34.

Barabel, M., Combes, M., Meier, O., \& Nicolaï, I. (2010). Perception and legitimating of CSR within a multinational firm: the case of the DEXIA Group. Revue internationale de psychosociologie, vol. xvi,(38), 191-208.

Bene, Á. (2016). A CSR különleges bánásmódja Különleges Bánásmód 2016/2, 27-41.

Creswell, J. W. (2009). Research Design. Qualitative, Quantitative and Mixed Methods Approaches. Sage Publications, CA, Thousand Oaks

Csapóné Riskó, T. (2016). Fókuszban az alkalmazottak, Studia Mundi-Economica, 3:(1) 2639.

Csukonyi, Cs., Máth, J., Medvés, D., \& Pántya, J. (2007). Munkahelyi beillesztés a megváltozott munkaképességü személyek munkaerö-piaci integrációjában In Münnich, Á. (szerk.), Gyakorlati megfontolások és kutatási tapasztalatok a megváltozott munkaképességü emberek foglalkoztatásához (25-45o.) Debrecen: Didakt Kkiadó

Dahlsrud, A. (2008). How Corporate Social Responsibility is Defined: an Analysis of 37 Definitions. Corporate Social Responsibility and Environmental Management 15., 113.

Dajnoki, K. (2014). Fogyatékos munkavállalók beillesztésének elösegítése, különös tekintettel az érzékenyítő tréningekre. Taylor, Gazdálkodás- és szervezéstudományi folyóirat VI. évf./1-2. szám No14-15., 157-168. 
Drucker, P. F. (1984). The new meaning of corporate social responsibility. California Management Review, Vol. 26, pp.53-63.

Faragó, T. (2015). A fenntartható fejlődés új ENSZ-programja, file://C:/torrent/SDGsFarag\%C3\%B3Tibor.pdf

Fedor, Gy., Münnich, Á., \& Sipos, S. (2007). A munkaadó szervezetek megváltozott munkaképességü munkavállalók foglalkoztatására való felkészültségének feltáró vizsgálata In Münnich, Á. (szerk.), Gyakorlati megfontolások és kutatási tapasztalatok a megváltozott munkaképességü emberek foglalkoztatásához (25-45 o.) Debrecen: Didakt Kkiadó

Géring, Zs. (2017). Kevert szövegelemzési módszertan alkalmazása gazdasági és társadalmi jelenségek vizsgálatához: Online CSR-kommunikáció vizsgálata tartalomelemzéssel és diskurzuselemzéssel, Vezetéstudomány, 48:(4), 55-66.

Herring, S. C. (2010). Web Content Analysis: Expanding the Paradigm. in: Hunsinger, J. Allen, M. - Klastrup, L. (eds): The International Handbook of Internet Research. Heidelberg: Springer Verlag

Kálmán, Zs., Könczei, Gy. (2002). A Taigetosztól az esélyegyenlöségig. Osiris

Kemény, P. (2015). Lépések a kiszámíthatóbb, emberséges foglalkoztatás felé. A foglalkozási rehabilitáció és a HR In: Soltész, A. (szerk.) Munkavállalók és munkáltatók a megváltozott munkaképességüek foglalkoztatási lehetöségüek foglalkoztatási lehetöségeiröl, esélyeiröl, proAbility, 93-109.

Király, G., Dén-Nagy, I., Géring, Zs., \& Nagy, B. (2014). Kevert módszertani megközelítések. Elméleti és módszertani alapok, Kultúra és Közösség, 5(2), 95-104.

KSH (2012). Megváltozott munkaképességüek a munkaerőpiacon, 2011. Budapest

Kun, A. (2009) A multinacionális vállalatok szociális felelőssége: CSR-alapú önszabályozás kontra (munka)jogi szabályozás, Ad Librum, Budapest

Kun Á. (2010). Munkahelyi szocializáció, beillesztés és alternatív foglalkoztatási formák a megváltozott munkaképességü egyéneknél, In: Juhász, M. (szerk.), A foglalkozási rehabilitáció támogatása pszichológiai eszközökkel, Typotex Kiadó, Budapest, 243-268.

Kurucz, O., Kemény, P. (2015) A megváltozott munkaképességü munkavállalók foglalkoztatását érintő jogszabályok és statisztikai háttér áttekintése In: Soltész, A. (szerk.) Munkavállalók és munkáltatók a megváltozott munkaképességüek foglalkoztatási lehetöségüek foglalkoztatási lehetöségeiröl, esélyeiröl, proAbility, 7-26.

Luetkenhorst, W. (2004). Corporate Social Responsibility and the Development Agenda. Intereconomics. 39 (3), 157-168.

Móré, M. (2012). Te csak beszélj, én könnyen beilleszkedem. A beillesztés kommunikációs összefüggései. A Virtuális Intézet Közép-Európa Kutatására Közleményei IV. évf. 2. sz. (No. 8.) A-sorozat 1. Szeged, 43-50.

Novak, M. (1996). Business as a Calling: Work and the Examined Life. The Free Press, NY.

Perrini, F. (2006). SMEs and CSR Theory: Evidence and Implications from an Italian Perspective. Journal of Business Ethics 67., 305-316.

Polyacskó, O. (2015). Korábbi kutatások a megváltozott munkaképességűek foglalkoztatásáról In: Soltész, A. (szerk.) Munkavállalók és munkáltatók a megváltozott munkaképességüek foglalkoztatási lehetöségüek foglalkoztatási lehetöségeiröl, esélyeiröl, proAbility, 52-62. 
Rayner, J. (2003). Managing Reputational Risk: Curbing Threats, Leveraging Opportunities. Institute of Internal Auditors Risk Management Series, Wiley,

Roberts, S., Heaver, C., Hill, K., Rennison, J., Stafford, B., Howat, N., Kelly, G., Krishnan, S., Tapp, P., \& Thomas, A. (2004). Disability in the workplace: Employers' and service providers' responses to the Disability Discrimination Act in 2003 and preparation for 2004 changes. (Letöltés: 2016.01.07.) (Web: www.webarchive.nationalarchives.gov.uk/20130314010347/http: / / gov.uk/asd/asd5/rports2003-2004/rrep202.pdf)

Sperkens, J. (2017). Growth through sustainability and partnerships, Céges Társadalmi Felelősségvállalás kultúrája Európában és Magyarországon Konferencia 2017.05.12. Budapesti Európai Ifjúsági Központ

Szabó, M., Kozicz, Á., \& Ottrok, V. (2012). AJB - 2618/2012 Jelentés (Letöltés: 2016.02.29.) (Web: http://tamogatoweb.hu/ekonyvtar_pdf/fogyatekossaggal-elok-foglalkoztatasihelyzete.pdf)

Tardos, K. (2015). Halmozódó diszkrimináció kirekesztés és integráció a munkaerőpiacon. Szeged: Belvedere Meridionale.

Waddock, S., Bodwell, C., \& Graves S. (2002). Responsibility: The New Business Imperative. The Academy of Management Executive 16(2), 132-147.

Watts, P., Holme, L. (1998). Meeting Changing Expectations - Corporate social responsibility. Geneva, WBCSD Report.

Törvények, kormányhatározat

2007. évi XCII. törvény a Fogyatékossággal élő személyek jogairól szóló (ENSZ) egyezmény és az ahhoz kapcsolódó Fakultatív Jegyzőkönyv kihirdetéséről

2011. évi. CXCI. törvény a megváltozott munkaképességű személyek ellátásairól és egyes törvények módosításáról (Mmtv.)

1025/2006.(III.23) Kormányhatározat, A munkáltatók társadalmi felelősségének erősítéséről és ezt ösztönző intézkedésekről

Internetes hivatkozások

Net1: vállalat honlapja Letöltés: 2017.01.01.-2017.10.08. többszöri)

Net2: anyavállalat honlapja Letöltés: 2017.01.01.-2017.08.01. többszöri)

Net3: www.ec.europa.eu/growth/industry/corporate-social-responsibility/index_en.htm Letöltés: 2016.01.11.

Net4: http://mef.forum.hu/index Letöltés: 2017.04.16.

Net5: www.salvavita.hu ketöltés: 2016.01.19.

Net6: http://www.segitovasarlas.hu Letöltés: 2017.05.26.

Net7: http://hotelpanda.hu/ Letöltés: 2017.05.26.

Net8: https://www.hatpottyos.hu/home Letöltés: 2017.05.26.

Net9: http://neo-interactive.hu/ Letöltés: 2017.05.26.

Net10: https://www.kockacsoki.com/ Letöltés: 2017.05.26.

Net11: www.//fbm.hu Letöltés: 2016.01.10.

Net12:http://www.menszt.hu/tudnivalok_az_egyesult_nemzetek_szervezeterol/fenntarthato_f ejlodesi_celok Letöltés: 2017.08.01. 
Net13: https://www.youtube.com/watch?v=tESU11KIoFE Letöltés:2017.10.20.

Net14: http://artman.hu/kik-vagyunk/rolunk/ Letöltés: 2017. október 14.

Net15: http://www.suhanj.hu/ Letöltés: 2017. október 14.

Net16: https://sokszinusegikarta.hu Letöltés: 2017. október 14.

\section{Függelék}

1. sz. függelék: ENSZ globális fejlődési célok (forrás:

http://www.menszt.hu/tudnivalok_az_egyesult_nemzetek_szervezeterol/fenntarthato_fejl odesi_celok)
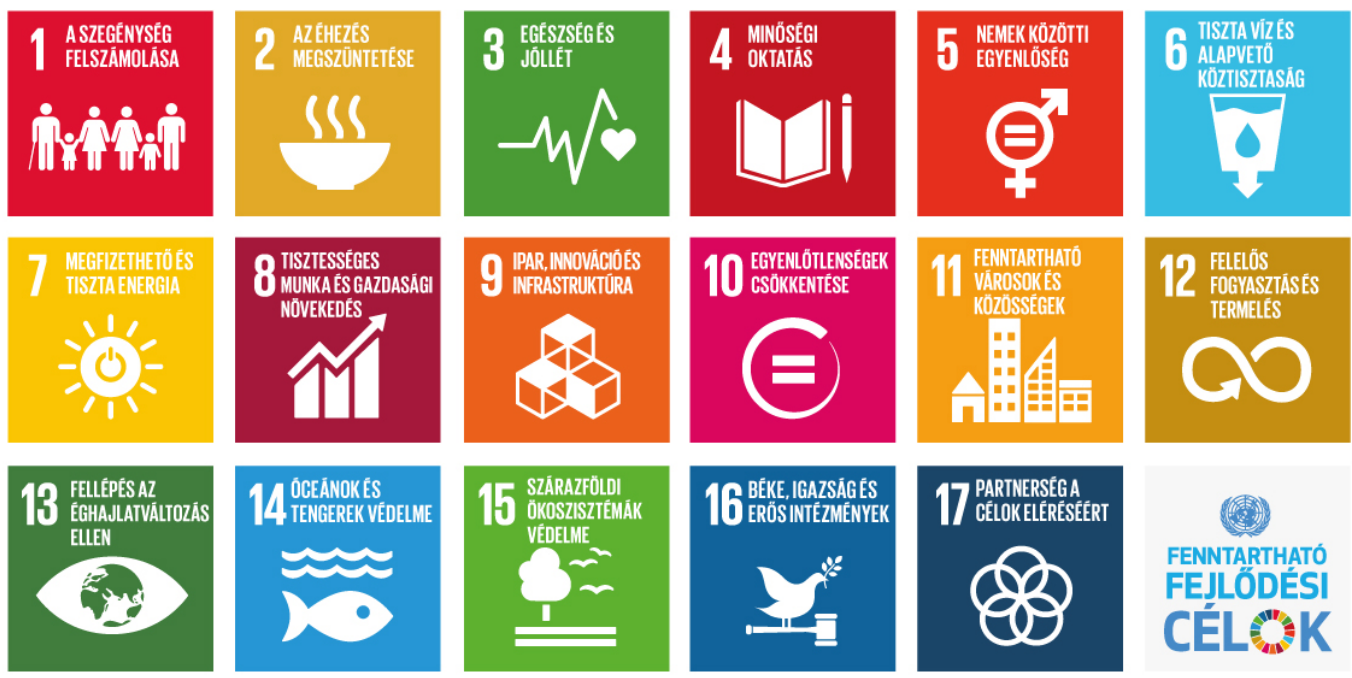

(7)

FENNTARTHATÓ FEJLÓDÉSI CÉLOK

2. sz. függelék:Fenntarthatósági témák fontossága a vállalat érdekeltjeinek körében (a változás értéke 2016-ban az előző évihez viszonyítva). forrás: saját szerkesztés a vállalat Fenntarthatósági Jelentés 2015 és 2016 alapján

\begin{tabular}{|l|l|l|l|l|l|l|l|l|l|}
\hline & Szabályozó & $\begin{array}{l}\text { Beszállító, } \\
\text { partner }\end{array}$ & $\begin{array}{l}\text { Civil } \\
\text { szervezet }\end{array}$ & Munkatárs & $\begin{array}{l}\text { Jövő } \\
\text { generáció }\end{array}$ & Befektető & $\begin{array}{l}\text { Helyi } \\
\text { közösség }\end{array}$ & Média & Ügyfél \\
\hline A & $2.0(-1.0)$ & $3.1(+0.3)$ & $3.0(-0.1)$ & $3.1(+0.3)$ & $2.8(+0.2)$ & $2.5(+0.2)$ & $2.3(-0.2)$ & $3.4(+0.7)$ & $2.6(+0.1)$ \\
\hline B & $3.0(-0.5)$ & $3.0(+0.1)$ & $3.2(+0.2)$ & $3.2(+0.7)$ & $2.6(0)$ & $2.5(+0.2)$ & $2.5(-0.1)$ & $3.2(+0.8)$ & $2.8(+0.3)$ \\
\hline C & $2.0(-0.5)$ & $2.6(+0.1)$ & $3.2(+0.6)$ & $2.7(0)$ & $2.3(-0.4)$ & $1.9(-0.5)$ & $1.9(-0.5)$ & $2,5(+0.2)$ & $2.2(-0.1)$ \\
\hline D & $1.0(-1.5)$ & $2.7(+0.3)$ & $3.0(+0.2)$ & $2.4(-0.2)$ & $2,2(-0.4)$ & $1.6(-0.9)$ & $2.0(-0.2)$ & $3.0(+0.7)$ & $2.1(-0.1)$ \\
\hline E & $3.0(+0.5)$ & $3.0(+0.5)$ & $2.5(+0.6)$ & $2.2(+0.1)$ & $2.1(+0.1)$ & $1.8(-0.5)$ & $1.8(+0.1)$ & $2.2(+0.5)$ & $2.2(+0.3)$ \\
\hline
\end{tabular}


3. sz. függelék CSR tevékenységek fogyatékosokkal, megváltozott munkaképességüekkel kapcsolatban (forrás: Bene, 2016. 37.o.)

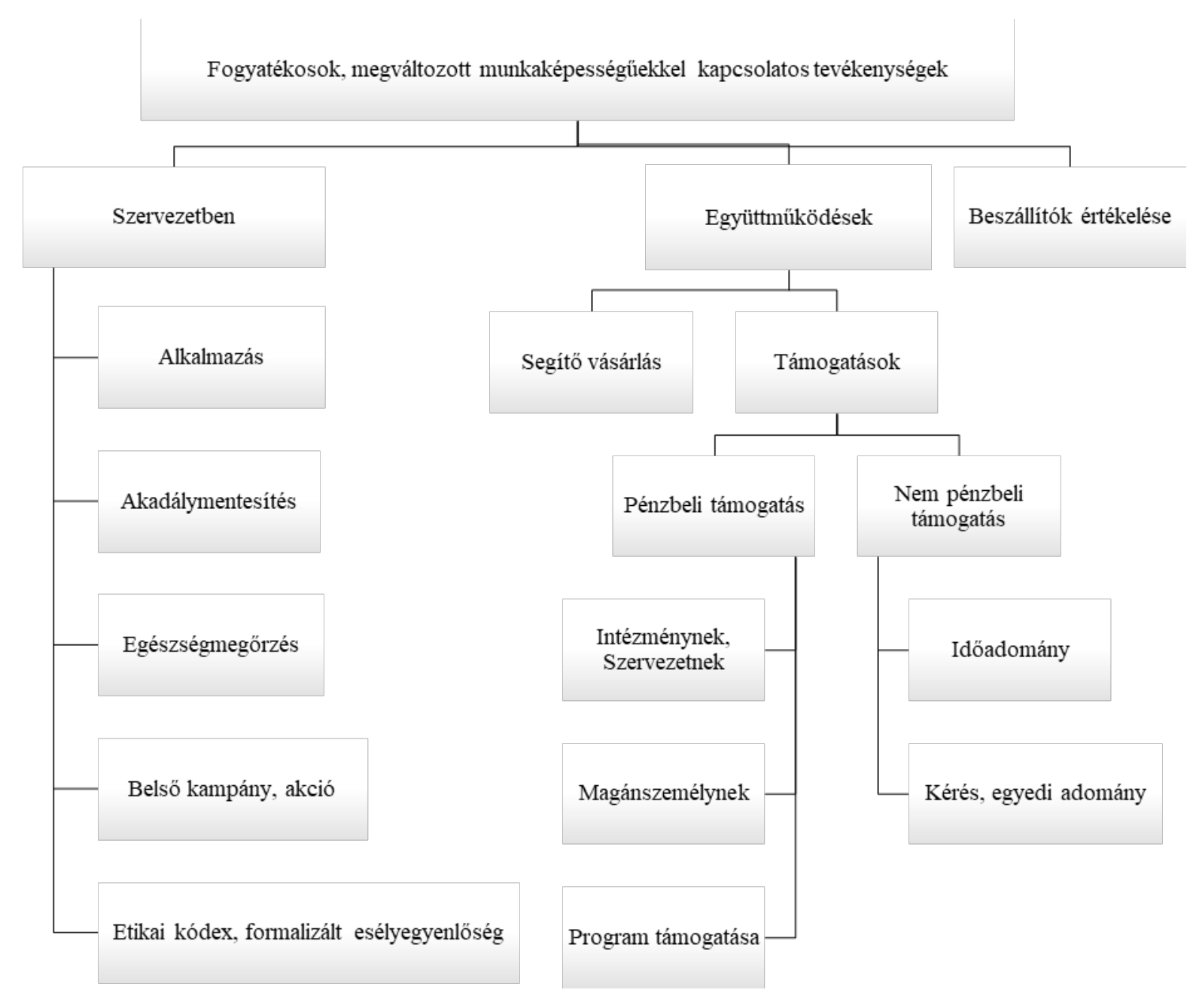

